\title{
Pseudo-nitzschia physiological ecology, phylogeny, toxicity, monitoring and impacts on ecosystem health
}

\author{
Vera L. Trainer ${ }^{\mathrm{a}, *}$, Stephen S. Bates ${ }^{\mathrm{b}}$, Nina Lundholm ${ }^{\mathrm{c}}$, Anne E. Thessen ${ }^{\mathrm{d}}$, William P. Cochlan ${ }^{\mathrm{e}}$, \\ Nicolaus G. Adams ${ }^{\mathrm{a}}$, Charles G. Trick ${ }^{\mathrm{f}, \mathrm{g}}$ \\ ${ }^{a}$ NOAA, Marine Biotoxins Program, Northwest Fisheries Science Center, National Marine Fisheries Service, National Oceanic and Atmospheric Administration, \\ 2725 Montlake Blvd. E., Seattle, WA 98112, USA \\ ${ }^{\mathrm{b}}$ Fisheries and Oceans Canada, Gulf Fisheries Centre, P.O. Box 5030, Moncton, New Brunswick, Canada E1C 9B6 \\ ${ }^{\mathrm{c}}$ Natural History Museum of Denmark, University of Copenhagen, Sølvgade 83S, DK-1307 Copenhagen K, Denmark \\ ${ }^{\mathrm{d}}$ Center for Library and Informatics, Marine Biological Laboratory, 7 MBL Street, Woods Hole, MA 02543, USA \\ ${ }^{\text {e }}$ Romberg Tiburon Center for Environmental Studies, San Francisco State University, 3152 Paradise Drive, Tiburon, CA 94920, USA \\ ${ }^{\mathrm{f}}$ Department of Biology, Schulich School of Medicine and Dentistry, University of Western Ontario, Ontario, Canada N6A 5B7 \\ ${ }^{\mathrm{g}}$ Department of Microbiology \& Immunology, Schulich School of Medicine and Dentistry, University of Western Ontario, Ontario, Canada N6A 5B7
}

\section{A R T I C L E I N F O}

\section{Article history:}

Available online 3 November 2011

\section{Keywords:}

Algal phylogeny

Algal taxonomy

Amnesic shellfish poisoning

Diatom sexual reproduction

Domoic acid

Harmful algal bloom

Pseudo-nitzschia

\begin{abstract}
A B S T R A C T
Over the last decade, our understanding of the environmental controls on Pseudo-nitzschia blooms and domoic acid (DA) production has matured. Pseudo-nitzschia have been found along most of the world's coastlines, while the impacts of its toxin, DA, are most persistent and detrimental in upwelling systems. However, Pseudo-nitzschia and DA have recently been detected in the open ocean's high-nitrate, lowchlorophyll regions, in addition to fjords, gulfs and bays, showing their presence in diverse environments. The toxin has been measured in zooplankton, shellfish, crustaceans, echinoderms, worms, marine mammals and birds, as well as in sediments, demonstrating its stable transfer through the marine food web and abiotically to the benthos. The linkage of DA production to nitrogenous nutrient physiology, trace metal acquisition, and even salinity, suggests that the control of toxin production is complex and likely influenced by a suite of environmental factors that may be unique to a particular region. Advances in our knowledge of Pseudo-nitzschia sexual reproduction, also in field populations, illustrate its importance in bloom dynamics and toxicity. The combination of careful taxonomy and powerful new molecular methods now allow for the complete characterization of Pseudo-nitzschia populations and how they respond to environmental changes. Here we summarize research that represents our increased knowledge over the last decade of Pseudo-nitzschia and its production of DA, including changes in worldwide range, phylogeny, physiology, ecology, monitoring and public health impacts.
\end{abstract}

Published by Elsevier B.V.

\section{Introduction}

Since the discovery of domoic acid (DA) as a human health problem, causing amnesic shellfish poisoning (ASP), off Prince Edward Island, Canada, in 1987 (Bates et al., 1989) and as a potent killer of wildlife in Monterey Bay, USA, in 1991 (Work et al., 1993a,b) and thereafter (Scholin et al., 2000; reviewed by Bejarano et al., 2008; Bargu et al., in press), the monitoring of Pseudonitzschia and its toxin, DA, has expanded to more coastlines of the world. Thus, the number of described of Pseudo-nitzschia species has climbed from 15 in the 1980s to $\sim 37$ in the 2010s, and the number of species confirmed to produce DA has risen to 12 (Trainer et al., 2010; Lundholm, 2011; listed in Fig. 1). The presence of

\footnotetext{
* Corresponding author. Tel.: +1 206860 6788; fax: +1 2068603335 .

E-mail address: Vera.L.Trainer@noaa.gov (V.L. Trainer).
}

Pseudo-nitzschia in high numbers during open ocean ironfertilization experiments (Trick et al., 2010) and the quantification of DA in both preserved and live samples from open ocean regions (Silver et al., 2010) have enhanced our understanding of the importance and wide distribution of Pseudo-nitzschia. It is found at a small scale, e.g. in thin layers (Rines et al., 2002), or at a large scale, covering wide expanses of our coastlines (e.g. Trainer et al., 2009a,b). Pseudo-nitzschia can form intense, high-density, visible blooms in bays, such as Monterey Bay, whereas offshore it more often forms less dense blooms that are not visible to the naked eye. Environmental cues causing toxic blooms of Pseudo-nitzschia are complex, and can be unique to the bays, coastal, or open ocean regions where they occur.

The cosmopolitan nature of most toxigenic Pseudo-nitzschia species (Hasle, 2002) argues for widespread human health effects of this toxin. However, since the deaths of humans as a result of the 1987 ASP event, no human mortalities have been confirmed, 


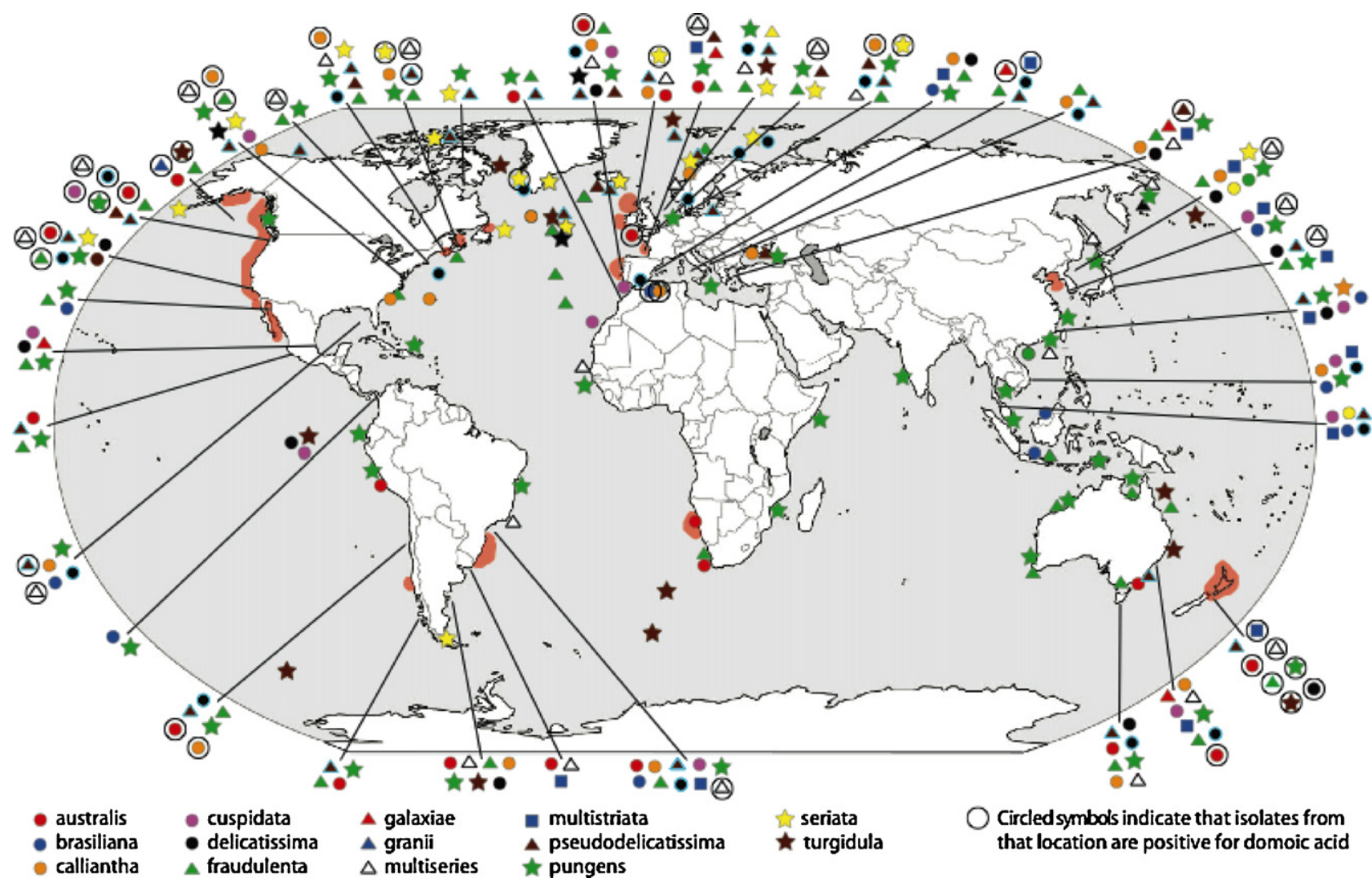

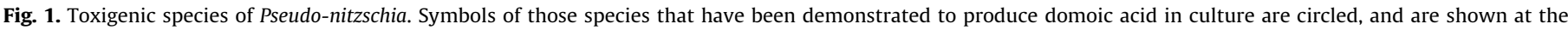

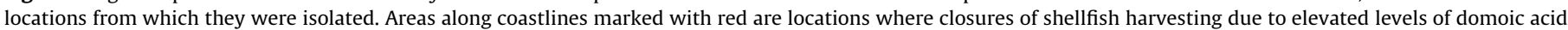

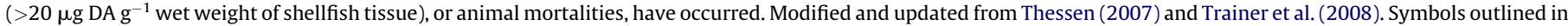
blue indicate a species description that was made before major taxonomic revisions were implemented for $P$. delicatissima and $P$. pseudodelicatissima.

thanks to effective implementation of monitoring programs. The presence of DA can nevertheless have negative economic consequences for harvesters of wild and aquacultured molluscan shellfish. Impacts of DA on marine wildlife at various levels within the food web have also been observed, and this toxin is known to contribute to the deaths of seabirds, sea otters, sea lions and whales. The adsorption of DA, especially to sediments (Burns and Ferry, 2007), facilitates its potentially long-lasting impacts, particularly to the benthic food chain. Here we summarize those impacts of DA on marine wildlife as well as our increased knowledge about Pseudo-nitzschia and DA over the last decade, including changes in worldwide range and impacts, phylogeny, physiology, ecology, monitoring and public health impacts.

\section{Worldwide range and impacts}

It is remarkable that, almost without exception, the impacts of DA have been described primarily in eastern boundary upwelling systems (Fig. 1; Trainer et al., 2008, 2010). Although Pseudonitzschia and low levels of DA are found in other regions, e.g. the Mediterranean, Russia, Japan and Vietnam, damaging blooms have generally not been noted. Therefore, this section will focus primarily on those systems in which DA has caused negative effects on human health or marine wildlife.

\subsection{United States}

\subsubsection{Fisheries and organisms affected}

Over the last decade, several cases of DA poisoning of finfish, marine mammals and birds have been documented on the U.S. West Coast, while human deaths have been prevented through routine monitoring of shellfish. In U.S. waters, a number of commonly harvested shellfish and finfish have been reported as vectors of the toxin, including blue mussels, clams (razor, littleneck, geoduck and manila), Pacific oysters, crabs (Dungeness, rock and pelagic red), spiny lobster viscera, anchovies, and sardines (Lewitus et al., in press; Table 1), each with differing rates of toxin retention and release. Marine animals, e.g. sea lions, sea otters and marine birds, have also been found to accumulate DA, leading to widespread transfer through marine food webs (e.g. Scholin et al., 2000; Lefebvre et al., 2002; Bargu and Silver, 2003; Bargu et al., 2008, 2010; Kvitek et al., 2008). Since the first recorded DA-related mortality of sea lions and seabirds in 1991 (Work et al., 1993a,b), death or illnesses have been reported in California sea lions, northern fur seals, harbour porpoises, common dolphins, sea otters, gray whales, brown pelicans, Brandt's cormorants, blackcrowned night herons, Pacific loons, red-throated loons, common loons, rhinoceros auklets, Cassin's auklets, ruddy ducks, surf scoters, short-tailed shearwaters, western grebes and Clark's grebes (F.M.D. Gulland, unpubl. data for marine mammals; D.A. Caron, unpubl. data for birds; from Lewitus et al., in press; Bejarano et al., 2008; Bargu et al., in press).

DA has been detected in seafood species in Washington State and California almost every year (Trainer and Suddleson, 2005; Langlois, 2007). In 2007, the highest DA concentration $\left(610 \mu \mathrm{g} \mathrm{DA} \mathrm{g}^{-1}\right)$ on the U.S. west coast was detected in mussels in California (Langlois, 2007). An expansion of Pseudo-nitzschiarelated shellfish closures into Puget Sound was reported in 2003 (Bill et al., 2006) and 2005 (Trainer et al., 2007), when blooms of $P$. pseudodelicatissima and $P$. australis caused significant commercial, recreational and tribal shellfish harvest losses. These closures led to concerns that DA events in northern Puget Sound might expand 
Evidence for the impact of Pseudo-nitzschia and domoic acid in the food web.

\begin{tabular}{|c|c|c|c|c|}
\hline \multicolumn{2}{|l|}{ Organism } & \multirow[t]{2}{*}{ Location } & \multirow[t]{2}{*}{ Evidence } & \multirow[t]{2}{*}{ Reference } \\
\hline Common name & Scientific name & & & \\
\hline \multicolumn{5}{|l|}{ Protists } \\
\hline Dinoflagellate & Gyrodinium sp. & Monterey Bay, CA & Frustules in fecal pellets & Buck et al. (2005) \\
\hline Dinoflagellate & Noctiluca scintillans & NW Spain & Cells in food vacuoles & Escalera et al. (2007) \\
\hline Dinoflagellate & Protoperidinium pellucidum & Pacific NW coast, WA & Grazed on DA in laboratory & Olson and Lessard (2010) \\
\hline Dinoflagellate & Protoperidinium spp. & Oslofjord, Norway & Abundances of Protoperidinium spp. tracked & Kjæret et al. (2000) \\
\hline \multicolumn{5}{|c|}{ abundances of Pseudo-nitzschia } \\
\hline Sand dollar & Dendraster excentricus & Monterey Bay, CA & DA in tissue & Goldberg (2003) and Kvitek et al. (2008) \\
\hline \multicolumn{5}{|r|}{ 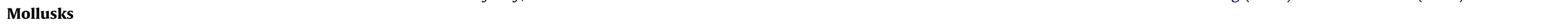 } \\
\hline Furrow shell & Scrobicularia plana & Portugal & DA in tissue & Vale et al. (1998) \\
\hline Olive snail & Olivella biplicata & Monterey Bay, CA & DA in tissue & Goldberg (2003) and Kvitek et al. (2008) \\
\hline Chilean blue mussel & Mytilus chilensis & Chile & DA in tissue & López-Rivera et al. (2009) \\
\hline Channeled basket whelk & Nassarius fossatus & Monterey Bay, CA & DA in tissue & Goldberg (2003) and Kvitek et al. (2008) \\
\hline California mussel & Mytilus californianus & San Diego, CA & DA in tissue & Busse et al. (2006) \\
\hline Mediterranean mussel & Mytilus galloprovincialis & Riá de Muros, Spain; Croatia; Portugal & DA in tissue & $\begin{array}{l}\text { Vale and Sampayo (2001), Blanco et al. (2002), } \\
\text { and Ujević et al. (2010) }\end{array}$ \\
\hline Blue mussel & Mytilus edulis & $\begin{array}{l}\text { New Brunswick, Canada; Nantucket Shoals; } \\
\text { Georges Bank; Washington coast; Argentina; } \\
\text { Japan; Ireland; Aviero Lagoon, Portugal }\end{array}$ & $\begin{array}{l}\text { DA in tissue, fed on Pseudo-nitzschia } \\
\text { in the lab and accumulated } \\
\text { DA; also in field samples }\end{array}$ & $\begin{array}{l}\text { Haya et al. (1991), Wohlgeschaffen et al. (1992), } \\
\text { Douglas et al. (1997), Horner and Postel (1993), } \\
\text { Kawatsu and Hamano (2000), Vale and } \\
\text { Sampayo (2001), Negri et al. (2004), and } \\
\text { James et al. (2005) }\end{array}$ \\
\hline Ribbed mussel & Aulacomya ater & Chile & DA in tissue & López-Rivera et al. (2009) \\
\hline Greenshell ${ }^{\mathrm{TM}}$ mussel & Perna canaliculus & New Zealand & $\begin{array}{l}\text { fed on Pseudo-nitzschia in lab } \\
\text { and accumulated DA }\end{array}$ & Mackenzie et al. (1993) \\
\hline Horse mussel & Modiolus modiolus & Atlantic Canada & DA in tissue & Gilgan et al. (1990) \\
\hline Mediterranean cockle & Acanthocardia tuberculatum & Algarve, Portugal & DA in tissue & Vale and Sampayo (2001) \\
\hline Common cockle & Cerastoderma edule & Mondego estuary and Aveiro Lagood, Portugal & DA in tissue & Vale and Sampayo (2001) \\
\hline King scallop & Pecten maximus & Scotland, Ireland; Morocco & DA in tissue & $\begin{array}{l}\text { Tahri-Joutei et al. (2003), Smith et al. (2006), } \\
\text { Campbell et al. (2003), and James et al. (2005) }\end{array}$ \\
\hline Mediterranean scallop & Pecten jacobaeus & Croatia & DA in tissue & Ujević et al. (2010) \\
\hline Sea scallop & Placopecten magellanicus & New Brunswick, Canada; Eastport, Maine & DA in digestive gland & $\begin{array}{l}\text { Shumway (1989), Haya et al. (1991), } \\
\text { Wohlgeschaffen et al. (1992), and Douglas et al. (1997) }\end{array}$ \\
\hline New Zealand scallop & Pecten novaezealandiae & New Zealand & DA in digestive gland & Rhodes et al. (1996), and Hay et al. (2000) \\
\hline Soft-shell clam & Mya arenaria & New Brunswick, Canada; Atlantic Canada & DA in tissue & Haya et al. (1991), and Gilgan et al. (1990) \\
\hline Spondylus clam & Spondylus versicolor & Vietnam, Philippines & DA in tissue & Dao et al. (2009) \\
\hline Razor clams & Siliqua patula & California/Washington/Oregon coasts & DA in tissue & $\begin{array}{l}\text { Horner et al. (1993), Horner and Postel (1993), and } \\
\text { Wekell et al. (1994) }\end{array}$ \\
\hline Razor clam & Ensis siliqua & Ireland & DA in tissue & James et al. (2005) \\
\hline Razor clam & Ensis spp. & Aveiro Lagoon, Portugal & DA in tissue & Vale and Sampayo (2002) \\
\hline Clam & Ruditapes decussata & Aveiro Lagoon, Portugal & DA in tissue & Vale and Sampayo (2002) \\
\hline Carpet shell & Venerupis pullastra & Aveiro Lagoon, Portugal & DA in tissue & Vale and Sampayo (2002) \\
\hline Calico clam & Tapes decussatus & Portugal & DA in tissue & Vale et al. (2008) \\
\hline Clam & Protothaca thaca & Chile & DA in tissue & López-Rivera et al. (2009) \\
\hline Proteus scallop & Flexopecten proteus & Croatia & DA in tissue & Ujević et al. (2010) \\
\hline European flat oyster & Ostrea edulis & Aveiro Lagoon, Portugal; Croatia & DA in tissue & Vale and Sampayo (2002), and Ujević et al. (2010) \\
\hline Pacific oyster & Crassostrea gigas & Puget Sound, WA & DA in tissue & Horner and Postel (1993) \\
\hline Common octopus & Octopus vulgaris & Portuguese coast & DA in gut, digestive gland, brachial heart & Costa et al. (2004) \\
\hline Squid & Loligo opalescens & Monterey Bay, CA & DA is tissues, frustules in stomach & Bargu et al. (2008) \\
\hline Common cuttlefish & Sepia officinalis & Portuguese coast & DA in digestive gland & Costa et al. (2005) \\
\hline \multicolumn{5}{|l|}{ Annelids } \\
\hline Polychaete worm & Poebius meseres & Monterey Bay, CA & frustules found in gut & Uttal and Buck (1996), and Buck et al. (1992) \\
\hline \multicolumn{5}{|l|}{ Echiurans } \\
\hline Fat innkeeper worm & Urechis caupo & Monterey Bay, CA & DA in tissue & Goldberg (2003), and Kvitek et al. (2008) \\
\hline \multicolumn{5}{|l|}{ Crustaceans } \\
\hline Sand crab & Emerita analoga & Monterey Bay, CA & DA in tissue & Goldberg (2003), and Kvitek et al. (2008) \\
\hline
\end{tabular}




\begin{tabular}{|c|c|c|}
\hline \multicolumn{2}{|l|}{ Organism } & \multirow[t]{2}{*}{ Location } \\
\hline Common name & Scientific name & \\
\hline Swimming crab & Polybius henslowii & Portuguese coast \\
\hline Blue band hermit crab & Pagurus samuelis & Monterey Bay, CA \\
\hline Blue crab & Callinectes sapidus & US Pacific Coast \\
\hline Rock crab & Cancer pagurus & US Pacific Coast \\
\hline Dungeness crab & Cancer magister & California/Oregon/Washington coasts \\
\hline Stone crab & Menippe adina & US Pacific Coast \\
\hline Ghost shrimp & Neotrypaea californiensis & Monterey Bay, CA \\
\hline Copepod & Acartia tonsa & \\
\hline Copepod & Acartia clausi & \\
\hline Copepod & Calanus finmarchicus & \\
\hline Copepod & Temora longicornis & \\
\hline Copepod & Calanus glacialis & \\
\hline Krill & Euphausia pacifica & Monterey Bay, CA \\
\hline Spiny lobster & Palinurus elephas & US Pacific Coast \\
\hline Gooseneck barnacle & Pollicipes pollicipes & Portugal \\
\hline \multicolumn{3}{|l|}{ Eurochordates } \\
\hline Tunicate & Pyura chilensis & Chile \\
\hline \multicolumn{3}{|l|}{ Fishes } \\
\hline Northern anchovy & Engraulis mordax & Monterey Bay, CA \\
\hline European anchovy & Engraulis encrasicolus & Portugal \\
\hline Argentine anchovy & Engraulis anchoita & Argentina \\
\hline Petrale sole & Eopsetta jordani & Monterey Bay, CA \\
\hline Sand sole & Psettichthys melanostictus & Monterey Bay, CA \\
\hline Slender sole & Eopsetta exillis & Monterey Bay, CA \\
\hline Rex sole & Errex zachirus & Monterey Bay, CA \\
\hline Dover sole & Microstomas pacificus & Monterey Bay, CA \\
\hline English sole & Pleuronectes vetulus & Monterey Bay, CA \\
\hline Curlfin turbot & Pleuronectes decurrens & Monterey Bay, CA \\
\hline Sand sole & Psettichthys melanostictus & Monterey Bay, CA \\
\hline Pacific halibut & Hippoglossus stenolepis & Monterey Bay, CA \\
\hline White croaker & Genyonemus lineatus & Santa Cruz, CA \\
\hline Staghorn sculpin & Leptocottus armatus & Santa Cruz, CA \\
\hline Jack mackerel & Trachurus symmetricus & Monterey Bay, CA \\
\hline Albacore & Thunnus alalunga & Monterey Bay, CA \\
\hline Mackerel & Scomber japonicus & $\begin{array}{l}\text { Cabo San Lucas, Mexico; Monterey Bay, } \\
\text { CA, San Diego, CA }\end{array}$ \\
\hline Jack mackerel & Trachurus symmetricus & San Diego, CA \\
\hline Herring & & Monterey Bay, CA \\
\hline Pilchard & Sardinops sagax & Baja California peninsula \\
\hline Pilchard & Sardina pilchardus & Portuguese coast; Namibian coast \\
\hline Pacific sanddab & Citharichthys sordidus & Monterey Bay, CA, San Diego, CA \\
\hline Albacore & Thunnas alalunga & Monterey Bay, CA \\
\hline Jack smelt & Atherinopsis californiensis & Monterey Bay, CA \\
\hline Gulf Menhaden & Brevoortia patronus & Gulf of Mexico \\
\hline Longspine combfish & Zaniolepis latipinnus & San Diego, CA \\
\hline \multicolumn{3}{|l|}{ Birds } \\
\hline Brown pelican & Pelecanus occidentalis & Monterey Bay, CA; Cabo San Lucas, Mexico \\
\hline Brandt's cormorant & Phalacrocorax penicillatus & Monterey Bay, CA \\
\hline Double-crested cormorant & Phalacrocorax auritus & Monterey Bay, CA \\
\hline Pelagic cormorant & Phalacrocorax pelagicus & Monterey Bay, CA \\
\hline
\end{tabular}

Evidence $\quad$ Reference

Costa et al. (2003)

DA in viscera, tissue $\quad$ Goldberg (2003), and Kvitek et al. (2008)

DA in tissue

DA in tissue

DA in tissue

$\mathrm{DA}$ in tissue

DA in tissue

Grazed on Pseudo-nitzschia in the lab, DA in tissue

Grazed on Pseudo-nitzschia in the lab, DA in tissue

Grazed on Pseudo-nitzschia in the lab, DA in tissue

Grazed on Pseudo-nitzschia in the lab, DA in tissue

Grazed on Pseudo-nitzschia in the lab

Frustules in gut and DA in tissue

DA in tissue

DA in tissue, feces and gut; frustules in gut

Frustules and DA in gut, DA in tissues

DA in tissue

DA in gastrointestine

DA in viscera

DA in viscera

DA in viscera

DA in viscera

DA in viscera

DA in viscera

DA in viscera

DA in viscera

DA in viscera

DA in viscera

DA in viscera

DA in viscera

DA in viscera

frustules and DA in gut

DA in viscera

frustules and DA in gut

frustules and DA in gut

frustules and DA in gut, DA in tissues

DA in viscera and tissue

DA in viscera

DA in viscera

frustules and DA in gut

DA in viscera

Altwein et al. (1995)

Horner and Postel (1993), and Wekell et al. (1994)

Altwein et al. (1995)

Goldberg (2003), and Kvitek et al. (2008)

Lincoln et al. (2001)

Maneiro et al. (2005)
Leandro et al. (2010a)

Lincoln et al. (2001), and Windust (1992)

Windust (1992)

Bargu et al. (2002), and Bargu and Silver (2003)

Altwein et al. (1995)

Vale and Sampayo (2002)

López-Rivera et al. (2009)

Fritz et al. (1992), Work et al. (1993a),

Lefebvre et al. (1999, 2002), Scholin et al. (2000), and Wekell et al. (1994)

Vale and Sampayo (2002)

Negri et al. (2004)

Vigilant and Silver (2007)

Vigilant and Silver (2007)

Vigilant and Silver (2007)
Vigilant and Silver (2007)

Vigilant and Silver (2007)
Vigilant and Silver, 2007

Vigilant and Silver (2007)

Vigilant and Silver (2007)

Vigilant and Silver (2007)

Vigilant and Silver (2007)

Fire and Silver (2005)

Fire and Silver (2005)

Busse et al. (2006)

Sierra-Beltrán et al. (1997), Lefebvre et al. (2002),

and Busse et al. (2006)

Busse et al. (2006)

Naar et al. (2002)

Sierra-Beltrán et al. (1998), and Lefebvre et al. (2002)

Costa and Garrido (2004), Vale and Sampayo (2002),

D. Louw, B. Currie, G. Doucette (pers. comm.)

Lefebvre et al. (2002), Busse et al. (2006),

Goldberg (2003), Kvitek et al. (2008),

and Vigilant and Silver (2007)

Lefebvre et al. (2002)

Lefebvre et al. (2002)

Del Rio et al. (2010)

Busse et al. (2006)

Frustules and DA in gut, death, neurological disorder

Frustules and DA in gut, death, neurological disorder Frustules and DA in gut, death, neurological disorder Frustules and DA in gut, death, neurological disorder

Fritz et al. (1992), Work et al. (1993a,b)

and Sierra-Beltrán et al. (1997)

Fritz et al. (1992), and Work et al. (1993a,b)

Fritz et al. (1992), and Work et al. (1993a,b)

Fritz et al. (1992), and Work et al. (1993a,b) 


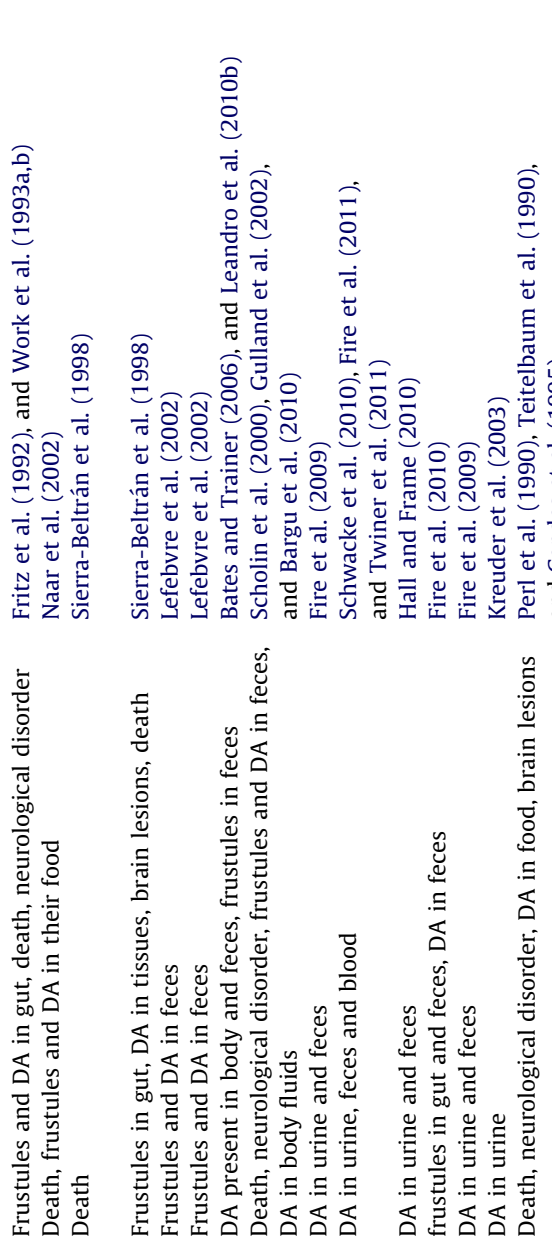

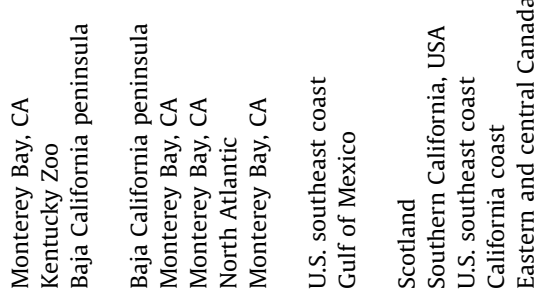
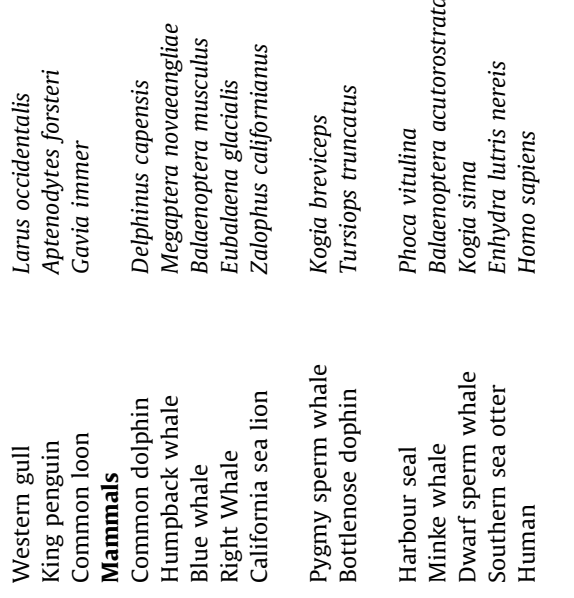

into areas further south, paralleling the expansion of paralytic shellfish toxicity into south Puget Sound in the 1990s (Trainer et al., 2003).

Further to the north, in the State of Alaska, shellfish are not routinely tested for DA; however, an intensive study in the 1990s found measurable levels of this toxin. In 1997, $11.5 \mu \mathrm{g} \mathrm{DA} \mathrm{g}^{-1}$ was measured in razor clams from Katchemak Bay and low levels were detected in Pacific anchovies from southeast Alaska (Alaska Dept. of Environmental Conservation database).

\subsubsection{Pseudo-nitzschia species}

Pseudo-nitzschia species are most often a minor component of the phytoplankton assemblage, contributing $<17 \%$ of the total carbon biomass, even in the most intense bloom observed off the Washington State coast (Trainer et al., 2009a). Pseudo-nitzschia spp. are common members of the coastal phytoplankton community and have been present in the California Current System at least since the 1930s (Gran and Thompson, 1930). The species associated with DA production are frequently present, albeit in low numbers, in most water samples (e.g. Walz et al., 1994). Of the 12 species of Pseudo-nitzschia known to produce DA around the world (Lundholm, 2011), 10 have been reported from the U.S. West Coast waters (Horner et al., 1997; Anderson et al., 2008). Pseudonitzschia spp. occur along the entire Alaskan coast (Bursa, 1963; Horner, pers. obs. as Nitzschia seriata), throughout the Bering Sea (Schandelmeier and Alexander, 1981 as Nitzschia spp., section Pseudo-nitzschia), and into the Gulf of Alaska (Cupp, 1943) and south-central Alaska (Horner et al., 1973; summarized in Lewitus et al., in press). Pseudo-nitzschia australis and P. multiseries are most commonly associated with toxic events throughout this region, with $P$. pseudodelicatissima and $P$. cuspidata also implicated in toxic events in Washington State waters (Adams et al., 2000; Trainer et al., 2009a). The most problematic species in California appear to be $P$. australis and P. multiseries (Trainer et al., 2000).

\subsubsection{Known "hot spots"}

Areas impacted by Pseudo-nitzschia span coastal Washington State, with a demonstrated "hot spot" in the Juan de Fuca eddy area, where Pseudo-nitzschia blooms occur relatively frequently, associated with high DA concentrations (Trainer et al., 2002). For DA to reach coastal beaches from the eddy region, toxic cells must first become concentrated enough to form a bloom, then must escape the eddy and travel southward toward the razor clamming beaches, move onto coastal beaches, and remain for a long enough period in the surf zone for a significant amount of the toxic cells to be ingested by the clams. The highest toxic cell concentrations, as well as onshore transport, occur during periods of downwelling winds (storms), whereas escape from the eddy and travel southward occur during periods of upwelling winds (MacFadyen and Hickey, 2010). Another initiation site, or "hot spot", for toxigenic Pseudo-nitzschia blooms is the Heceta Bank, off the Oregon coast (Trainer et al., 2000). The impact of DA toxicity on razor clam, mussel and Dungeness crab industries appears to be increasing in recent years, with exceptionally extensive and prolonged closures occurring from 2003 to 2005 (Tweddle et al., 2010). Additional hot spot areas in California include Monterey Bay, San Luis Obispo and Point Conception (Trainer et al., 2000).

An exceptional closure of DA-associated razor clam harvesting in Washington occurred in 2002-2003, for $\sim 1.5 \mathrm{y}$, resulting in an estimated \$10.4 million loss in revenue (HAB Report, 2009). A record high concentration of DA in razor clams $\left(295 \mu \mathrm{g} \mathrm{DA} \mathrm{g}^{-1}\right)$ was measured in 1998 (Adams et al., 2000). The total estimated impact of a hypothetical coast-wide seasonal closure of the recreational razor clam fishery for 2008 was estimated to be $\$ 21.9$ million and the income impact of the recreational razor clam fishery in Washington State for 2008 was estimated at $\$ 13.5$ 
million (Dyson and Huppert, 2010). Therefore, the economic impact of these toxic episodes on the U.S. west coast appears to have become more severe over the last decade.

While the impact of DA and occurrence of toxigenic Pseudonitzschia are greatest on the U.S. west coast where shellfish closures or animal mortalities occur frequently, other regions of the U.S. are also vulnerable to the same consequences. In the Gulf of Mexico, abundances of Pseudo-nitzschia have been increasing since the 1950s (Parsons et al., 2002) and time series of Pseudonitzschia spp. from sediment cores document increasing cell abundance in association with increased nutrient input from Mississippi River runoff (Parsons et al., 2002). Low levels of DA have been detected in menhaden (Table 1 ) and seawater samples off the Louisiana coast (Del Rio et al., 2010), where P. pseudodelicatissima, $P$. pungens, $P$. americana and $P$. calliantha are the dominant Pseudo-nitzschia species. High Pseudo-nitzschia abundance $\left(>10^{6}\right.$ cells $^{-1}$ ) has been associated with submarine ground discharge of nutrients off the coast of nearby Alabama (Liefer et al., 2009; MacIntyre et al., 2011). Toxic Pseudo-nitzschia spp. are present in the Chesapeake Bay, although their abundance and toxin production are highly variable. Six species of Pseudo-nitzschia have been identified in this area: P. pungens, $P$. calliantha, $P$. subpacifica, $P$. cuspidata, $P$. fraudulenta and $P$. multiseries. Compared to other diatom species, Pseudo-nitzschia abundances were low, rarely exceeding 1000 cells $\mathrm{ml}^{-1}$, and they did not occur as monospecific blooms. DA concentrations were generally low, ranging from 4 to $1037 \mathrm{pg} \mathrm{DA} \mathrm{ml}^{-1}$. Low Pseudo-nitzschia abundances and low, irregular DA concentrations may partially explain the lack of documented toxic events in the Chesapeake Bay (Thessen and Stoecker, 2008).

At least 9 Pseudo-nitzschia species are found in the Gulf of Maine, including $P$. delicatissima, $P$. fraudulenta, $P$. pungens, $P$. cf. subpacifica and $P$. delicatissima/pseudodelicatissima (Fernandes et al., 2009). In July, 2003, >20 whales, mostly humpbacks, were found dead near Georges Bank; DA was detected in most whales sampled, with several containing high concentrations (D.M. Anderson, pers. comm.). Later, DA was detected in fecal samples of the highly endangered North Atlantic right whale (Eubalaena glacialis) in the Gulf of Maine and Georges Bank, and in its food source (krill and copepods), from April to September of 2005 and 2006 (Leandro et al., 2010b).

\subsection{Canada}

\subsubsection{East coast}

DA, produced by $P$. multiseries, was identified as the source of the toxicity from Cardigan Bay (Prince Edward Island, eastern Canada), that resulted in the first ASP incident in the world, in 1987 (review by Bates et al., 1998). It is also the first time that a diatom produced a phycotoxin. The toxin reached among the highest levels recorded (790 $\mu \mathrm{g} \mathrm{DA} \mathrm{g}^{-1}$ ), in blue mussels (Mytilus edulis), and at lower levels (38 $\mathrm{g} \mathrm{DA} \mathrm{g}^{-1}$ ), in soft-shell clams (Mya arenaria) (Bates et al., 1989). An expanded shellfish monitoring program, implementing regulatory closures of harvesting sites when DA levels reach the regulatory limit $\left(20 \mu \mathrm{g} \mathrm{DA} \mathrm{g}^{-1}\right.$; now adopted internationally), has subsequently prevented any further cases of ASP in Canadian consumers. However, there have been subsequent harvesting closures along the eastern Canadian coastline (Table 2). The original 1987 event was followed by closures in Cardigan Bay in 1987, 1988 and 1999, but with decreasing concentrations of $P$. multiseries and of DA in mussels (summarized in Bates et al., 1998). Northern Prince Edward Island experienced short closures of harvesting in 1990, 1991, 1992, 1993 and 1999 (Bates, 2004). The presence of $P$. multiseries diminished after 1999, being replaced by nontoxic $P$. pungens and $P$. calliantha. The last harvesting closure was in 2002, covering most of the southern Gulf of St. Lawrence, but this time it was caused by a massive bloom of toxic $P$. seriata (Table 2) (Bates et al., 2002). Since then, there have been no shellfish harvesting closures due to toxic Pseudo-nitzschia blooms in the Gulf of St. Lawrence.

On the southwest shore of Nova Scotia, DA was found in June 1995 at levels near or exceeding the action level in some samples of soft-shell ( $M$. arenaria), propeller (Cyrtodaria siliqua) and surf (Spisula solidissima) clams, blue mussels (M. edulis), quahaugs (Mercenaria mercenaria), Stimpson's surf clam (Mactromeris polynyma), Jonah crabs (Cancer borealis), American lobster (Homarus americanus) hepatopancreas and sea scallop (Placopecten magellanicus) digestive glands collected along the southwest coast of Nova Scotia (unpublished data). The toxin source is unknown.

Just prior to the above incidence, high levels of DA were found in sea scallops ( $P$. magellanicus) from Georges, German, and Browns Banks. The sample with the highest toxin concentration analyzed showed the following tissue distribution: digestive gland $\left(3400 \mu \mathrm{g} \mathrm{DA} \mathrm{g}^{-1}\right)$, roe $\left(55 \mu \mathrm{g} \mathrm{DA} \mathrm{g}^{-1}\right)$, gills plus mantle $\left(19 \mu \mathrm{g} \mathrm{DA} \mathrm{g}^{-1}\right)$ and adductor muscle $\left(1 \mu \mathrm{g} \mathrm{DA} \mathrm{g}^{-1}\right.$ ) (unpublished data). Again, the DA source is not known, but it is possible that a bloom of toxic Pseudo-nitzschia growing in the upper, sunlit layers of the ocean settled to the benthos, where it was fed upon by the scallops.

The second location in the world where shellfish harvesting was closed due to DA was in the Bay of Fundy, eastern Canada, during September 1988 to December 1988 (Gilgan et al., 1990; Haya et al., 1991). Soft-shell clams (M. arenaria) were contaminated by DA from blooms of $P$. pseudodelicatissimacomplex species; it may have been $P$. calliantha (Lundholm et al., 2003) but its identity is still in dispute (Lundholm et al., in press). Also in the Bay of Fundy, elevated concentrations of DA $\left(\sim 100 \mu \mathrm{g} \mathrm{DA} \mathrm{g}^{-1}\right)$ were found in the digestive gland of cultured sea scallops (P. magellanicus) from Digby, Nova Scotia, in July 1996 (unpublished data). DA concentrations and toxic Pseudonitzschia species have not been detected at any significant levels since then.

\subsubsection{West coast}

In British Columbia, the first recorded incidence of DA was in 1992 (Forbes and Chiang, 1994). DA has been found in razor clams (Siliqua patula), native littleneck clams (Protothaca staminea), manila clams (Tapes philippinarum), horse clams (Tresus capax and/or T. nuttalli), Pacific oysters (Crassostrea gigas), California mussels (Mytilus californianus), blue mussels ( $M$. edulis), geoducks (Panope abrupta), Dungeness crabs (Cancer magister) and red rock crabs (Cancer productus). Between August 1992 and May 1993, the main areas affected were along the west coast of Vancouver Island, primarily in Quatsino, Clayoquot and Barkley Sounds, with additional isolated locations on Graham Island in the Queen Charlotte Islands, the Central Coast, and the Desolation Sound area of the inner South Coast. After September 1993, DA became even more widely distributed, occurring at additional locations, e.g. the Queen Charlotte Islands, on the North Coast and in inner South Coast waters. Recorded peak concentrations of DA are $277 \mu \mathrm{g} \mathrm{DAg}^{-1}$ (in crab viscera; September 1992, Quatsino Sound) and $112 \mu \mathrm{g} \mathrm{DA} \mathrm{g}^{-1}$ (in razor clams; September 1992, Cox Bay, near Tofino) (Department of Fisheries and Oceans, 1992). Since then, the highest DA level was $106 \mu \mathrm{g} \mathrm{DA} \mathrm{g}^{-1}$, on the north central west coast of Vancouver Island during March 2002 (Lewitus et al., in press). Quatsino Sound was closed to harvesting of crabs in August 1992, and again October 1993, due to excessive levels of DA. As well, portions of Barkley Sound were closed to harvesting of crabs and all molluscan shellfish in November 1993. Low levels of DA from the second event persisted in razor clams from the Queen Charlotte Islands and in molluscan shellfish from Barkley Sound 
Table 2

Closures of molluscan shellfish harvesting, caused by domoic acid. nr: not reported.

\begin{tabular}{|c|c|c|c|c|}
\hline Location & Dates & Organisms affected & $\begin{array}{l}\text { Dominant species } \\
\text { of Pseudo-nitzschia }\end{array}$ & Reference \\
\hline $\begin{array}{l}\text { Eastern Prince Edward } \\
\text { Island, Canada }\end{array}$ & December 1987-January 1988 & Blue mussel (Mytilus edulis) & P. multiseries & Bates et al. (1989) \\
\hline $\begin{array}{l}\text { Northern Prince Edward } \\
\text { Island, Canada }\end{array}$ & Autumn of 1991, 1992, 1994, 2000, 2001 & Blue mussel (Mytilus edulis) & P. multiseries & Bates (2004) \\
\hline Bay of Fundy, Canada & September 1988-December 1988 & Soft-shell clam (Mya arenaria) & P. pseudodelicatissima ${ }^{\mathrm{a}}$ & Gilgan et al. (1990), and Haya et al. (1991) \\
\hline Coastal Washington, USA & $\begin{array}{l}\text { 1991, 1993, 1995, 1998-1999, 2002, } \\
2003,2004,2005,2006\end{array}$ & Razor clam (Siliqua patula) & $\begin{array}{l}\text { P. cf. pseudodelicatissima, } \\
\text { P. australis }\end{array}$ & $\begin{array}{l}\text { Adams et al. (2000), Wekell et al. (2002), } \\
\text { Trainer and Suddleson (2005), } \\
\text { and Washington State Department of } \\
\text { Health database. }\end{array}$ \\
\hline $\begin{array}{l}\text { Quatsino Sound, British } \\
\text { Columbia, Canada }\end{array}$ & August 1992, October 1993 & Dungeness crab (Cancer magister) & $\mathrm{nr}$ & Department of Fisheries and Oceans (1992) \\
\hline $\begin{array}{l}\text { Barkley Sound, British } \\
\text { Columbia, Canada }\end{array}$ & November 1993 & $\begin{array}{l}\text { Razor clam (Siliqua patula); } \\
\text { Dungeness crab (Cancer magister) }\end{array}$ & $\mathrm{nr}$ & Department of Fisheries and Oceans (1992) \\
\hline New Zealand & $\begin{array}{l}\text { Various dates between } 1994 \\
\text { and 1999; review } \\
\text { pending for } 2000-2010\end{array}$ & $\begin{array}{l}\text { New Zealand scallop } \\
\text { (Pecten novaezealandia); } \\
\text { Greenshell }^{\mathrm{TM}} \text { mussel (Perna canaliculus) }\end{array}$ & P. australis & Hay et al. (2000), L. Rhodes (pers. comm.) \\
\hline Galicia, Spain & 1995,1996 & Scallop (P. maximus, P. jacobeus) & P. australis & Arévalo et al. (1998), and Fraga et al. (1998) \\
\hline West coast of Scotland & June 1999-April 2000 & King scallop (Pecten maximus) & P. australis & Gallacher et al. (2001) \\
\hline Southeast coast of Ireland & December 1999-May 2000 & King scallop (Pecten maximus) & P. australis & James et al. (2005), and Bogan et al. (2007a,b) \\
\hline Coastal Portugal & $\begin{array}{l}\text { Periodic closures lasting } 1 \text { week; } \\
\text { mostly in May of various years }\end{array}$ & $\begin{array}{l}\text { Common cockle (Cerastoderma edule); } \\
\text { Peppery furrow shell (Scrobicularia plana); } \\
\text { blue mussel (Mytilus edulis) }\end{array}$ & P. australis & Vale and Sampayo $(2001,2002)$ \\
\hline California, USA & 2000-2009 & $\begin{array}{l}\text { Blue mussel (Mytilus edulis), } \\
\text { lobster viscera }\end{array}$ & P. australis, P. multiseries & Trainer et al. (2000), and Langlois (2001-2009) \\
\hline $\begin{array}{l}\text { Southern Gulf of } \\
\text { St. Lawrence, Canada }\end{array}$ & April 2002-June 2002 & Blue mussel (Mytilus edulis) & P. seriata & Bates et al. (2002) \\
\hline Baie de Seine, France & November 2004-“several months” & King scallop (Pecten maximus) & P. australis or P. multiseries & Nézan et al. (2006) \\
\hline West coast of Ireland & April 2005 & Blue mussel (Mytilus edulis) & $\mathrm{nr}$ & Bogan et al. (2006) \\
\hline Puget Sound, Washington, USA & $\begin{array}{l}\text { September 2003; } \\
\text { October 2005-November } 2005\end{array}$ & Blue mussel (Mytilus edulis) & $\begin{array}{l}\text { P. australis, } \\
\text { P. pseudodelicatissima }\end{array}$ & Bill et al. (2006), and Trainer et al. (2007) \\
\hline Oregon, USA & 1991, 1998, 2003, 2004, 2005 & $\begin{array}{l}\text { Razor clam (Siliqua patula), } \\
\text { blue mussel (Mytilus edulis) }\end{array}$ & P. australis & Tweddle et al. (2010) \\
\hline Denmark, various locations & March-April 2005 & Blue mussel (Mytilus edulis) & P. seriata & Lundholm et al. (2005a) \\
\hline Santa Catarina State, Brazil & January 2009-February 2010 & Brown mussel (Perna perna) & $\mathrm{nr}$ & Reported in Fernandes and Brandini (2010) \\
\hline
\end{tabular}


until the autumn of 1994. In the fall of 1995, razor clam harvesting was again suspended in the northern Queen Charlotte Islands, due to high levels of DA. Incidences of DA contamination have since decreased.

The responsible organism(s) in coastal British Columbia waters has not yet been determined. However, the known DA producers $P$. multiseries, $P$. australis, $P$. pseudodelicatissima and $P$. seriata are present (Forbes and Denman, 1991; Taylor et al., 1994; Taylor and Haigh, 1996). Pseudo-nitzschia spp. are usually a minor component of the phytoplankton population off the southwest coast of Vancouver Island in late summer, but there is substantial variability and species may occur throughout the year. Species are also found in the Strait of Georgia and north of Vancouver Island. Pseudo-nitzschia spp. are present and often abundant in all coastal waters throughout the summer and fall, e.g. Sechelt Inlet (Taylor et al., 1994), but the most intense blooms have occurred over the outer continental shelf (Forbes and Denman, 1991). Taylor and Haigh (1996) observed that blooms enter Barkley Sound from the open coast and then appear to sink.

\subsection{Mexico}

Several countries in Latin America are surrounded by two oceans, so it is not surprising that they are vulnerable to HABs, including those caused by toxigenic species of Pseudo-nitzschia. Considering the wide-spread presence of these diatoms, there have been few negative impacts that can be linked specifically to DA.

Of the $\sim 21$ described Pseudo-nitzschia species in Mexican waters, at least 10 are toxic or potentially toxic. On the Pacific coast: $P$. australis, $P$. brasiliana, $P$. fraudulenta and $P$. pungens. On the Gulf of Mexico coast: P. australis, P. calliantha, P. cuspidata, $P$. galaxiae, $P$. australis, $P$. pseudodelicatissima (which may be any from the $P$. pseudodelicatissima complex) and $P$. pungens. Nontoxic species include: $P$. americana, $P$. inflatula, $P$. lineola, $P$. roundii (although not yet tested), $P$. subfraudulenta, $P$. arenysensis, $P$. caciantha, $P$. decipiens, $P$. subfraudulenta and $P$. subpacifica (Hernández-Becerril, 1998; Hasle, 2002; Hernández-Becerril and Díaz-Almeyda, 2006; Hernández-Becerril et al., 2007; QuijanoScheggia et al., 2011).

The first indication that DA was a problem was in 1996, when 150 brown pelicans (Pelecanus occidentalis) and cormorants (Phalacrocorax penicillatus) from the southern Baja California peninsula showed abnormal behaviors or died (Sierra-Beltrán et al., 1997). This bird mortality event was similar to the one described by Work et al. (1993a,b) in Monterey Bay, USA. Unidentified Pseudo-nitzschia spp. and DA were detected in the birds' stomachs; stomach extracts caused the characteristic abnormal behavior and death in mice injected intraperitoneally. DA was also found in the birds' food, mackerel (Scomber japonicus). Several other mortality events have since occurred, although it was not possible to make a definitive link to DA. For example, another massive mortality of sea birds and marine mammals occurred in the winter of 1997, on the east coast of the Baja California peninsula (Ernesto García-Mendoza, pers. comm.). In 2002, Pseudo-nitzschia spp. were associated with the sickness or death of 87 sea lions (Zalophus californianus) on the beaches in northern Baja California (Hernández-Becerril et al., 2007). Additional events consistent with DA toxicity have been identified. In 2002, 87 sea lions were found stranded on beaches from the border of the USA to Ensenada, on the Baja peninsula, and it was assumed that DA toxicity was the cause of this event (Hernández-Becerril et al., 2007). As well, there were mass mortalities of sea mammals and birds in 1995 and 2004, in the Gulf of California. However, there was no hard evidence to pinpoint DA as the cause of the mortalities (Ochoa et al., 2002; Sierra-Beltrán et al., 2005).
At times Pseudo-nitzschia spp. have bloomed, but without significant accumulation of DA or death of animals. DA was detected in net phytoplankton samples dominated by $P$. fraudulenta during upwelling in June-July 2006, at La Paz, southern Gulf of California (Gárate-Lizárraga et al., 2007). Strains of this species have been shown to produce low levels of DA only in New Zealand (Rhodes et al., 1998), Monterey Bay, California, USA (Wells et al., 2005) and Chesapeake Bay, Maryland, USA (Thessen et al., 2009), but nowhere else. No P. fraudulenta isolates from the Gulf of California were available for toxicity testing. Only low levels of DA $\left(0.55 \mu \mathrm{g} \mathrm{DA} \mathrm{g}^{-1}\right)$ were detected in chocolate clams (Megapitaria squalida). Another toxic bloom occurred in Todos Santos Bay, on the Pacific coast of the Baja California peninsula, during upwelling in April 2007 (García-Mendoza et al., 2009). A maximum DA concentration of $0.86 \mu \mathrm{g} \mathrm{DA}^{-1}$ in the plankton was associated with the presence of $P$. australis that reached a maximum abundance of $3 \times 10^{5}$ cells $^{-1}$, and a maximum calculated specific toxicity of $42 \mathrm{pg} \mathrm{DA} \mathrm{cell}^{-1}$. No adverse biological effects were detected. This is the southernmost report of the presence of DA in the California Current System. The above events suggest that the incidences and geographic extent of animal mortalities and toxic Pseudo-nitzschia blooms may be increasing in Mexican waters.

\subsection{South America}

In South America, Pseudo-nitzschia australis was one of the first known Pseudo-nitzschia species, recorded in 1939 by Joaquín Frenguelli, from the Golfo de San Matías, Argentina (Sar et al., 1998). Since then, it has been found not just in the southern hemisphere, but in most coastal areas, curiously with the exceptions of the eastern Atlantic and Asia. It is thus considered cosmopolitan (Hasle, 2002) and is the most common toxic Pseudonitzschia species in South America. What had been called $P$. seriata in Californian waters is actually P. australis; the two had been confused up until the $1960 \mathrm{~s}$, because they both have wide cells. $P$. australis, along with several others, continues to be problematic in waters of several South American countries. Although P. australis has been reported in Peruvian waters (Hasle, 1965), there have thus far been no reports of toxic blooms or DA in the food web.

\subsubsection{Chile}

DA was first discovered in South America near Puerto Montt, south-central Chile, in March 1997, in clams (Venus antiqua; $15.7 \mu \mathrm{g} \mathrm{DA} \mathrm{g}^{-1}$ ), at levels just below the regulatory limit (reported in Ferrario et al., 2002). Later, in 1999-2000, DA was found in scallops (Argopecten purpuratus; $62.4 \mu \mathrm{g} \mathrm{DA} \mathrm{g}^{-1}$ ) and clams (Protothaca taca; $330 \mu \mathrm{g} \mathrm{DA} \mathrm{g}^{-1}$ ) in central Chile (Suárez-Isla et al., 2002). Each event was associated with blooms of $P$. australis. Strains of this species, as well as of $P$. calliantha, from Northern Chile, were confirmed to produce DA in culture (Álvarez et al., 2009; Table 3). In the Magellan region of southern Chile, $P$. australis and $P$. pseudodelicatissima (which may actually be any of the $P$. pseudodelicatissima-complex species) have been registered during monitoring activities since 1994, along with trace levels of DA found in phytoplankton samples, although not associated with any ASP events (Suárez-Isla et al., 2002). Significant DA concentrations (up to $\sim 70 \mu \mathrm{g} \mathrm{DA} \mathrm{g}^{-1}$ whole animal; $15.5 \mu \mathrm{g} \mathrm{DA} \mathrm{g}^{-1}$ in edible tissues) were later found in the tunicate Pyura chilensis, in Bahía Inglesa, central Chile, during a bloom of $P$. australis (López-Rivera et al., 2009). This is the first report of DA in a tunicate, which is important because some of its tissues are consumed by humans. Other bivalve molluscs (Mytilus chilensis, Aulacomya ater, Protothaca thaca) at this aquaculture region contained sub-toxic levels of DA (Table 1). The presence of the above toxigenic Pseudonitzschia species, in addition to the potentially toxigenic 
Table 3

Species of Pseudo-nitzschia proven to produce domoic acid (DA) in laboratory culture. nr: not reported.

\begin{tabular}{|c|c|c|c|c|}
\hline Species & $\begin{array}{l}\text { Max DA concentration } \\
\left(\text { pg DA cell }^{-1}\right)\end{array}$ & $\begin{array}{l}\text { DA quantitation } \\
\text { method used }\end{array}$ & Origin of isolate & Reference \\
\hline \multirow[t]{14}{*}{ P. australis } & 37 & HPLC-UVD $^{\mathrm{d}}$ & Monterey Bay, CA, USA & Garrison et al. (1992) \\
\hline & 2.0 & HPLC-UVD & Bream Bay, New Zealand & Rhodes et al. (1996) \\
\hline & $\mathrm{nr}$ & HPLC-FMOC ${ }^{\mathrm{e}}$ & Ría de Vigo, Spain & Fraga et al. (1998) \\
\hline & $\mathrm{nr}$ & ELISA $^{\mathrm{f}}$ & Australia & Lapworth et al. (2001) \\
\hline & 3.5 & HPLC-UVD & Colonsay, Scotland & Campbell et al. (2001) \\
\hline & 27 & LC-MS & Waterford Harbour, Ireland & Cusack et al. (2002) \\
\hline & 1.1 & LC-MS/MS ${ }^{\mathrm{h}}$ & Bay of Plenty, New Zealand & Rhodes et al. (2004) \\
\hline & 1.68 & HPLC-FMOC & Lynn of Lorne, Scotland & Fehling et al. (2004b) \\
\hline & 3 & ELISA & Monterey Bay, CA, USA & Wells et al. (2005) \\
\hline & 0.026 & $\mathrm{RBA}^{\mathrm{i}}$ & Offshore Washington State, USA & Baugh et al. (2006) \\
\hline & 1.74 & LC-MS/MS & Bahía La Herradura, Chile & Álvarez et al. (2009) \\
\hline & 19.5 & cELISA $^{\mathrm{j}}$ & Point Reyes, California, USA & Bill (2011) \\
\hline & 21.85 & & Monterey Wharf, CA, USA & Guannel et al. (2011) \\
\hline & 3.3 & ELISA & Todos Santos Bay, Mexico & $\begin{array}{l}\text { Santiago-Morales and } \\
\text { García-Mendoza (2011) }\end{array}$ \\
\hline P. brasiliana & 0.0095 & HPLC-FMOC & Bizerte Lagoon, Tunisia & Sahraoui et al. (2011) \\
\hline \multirow[t]{5}{*}{ P. calliantha } & 0.098 & HPLC-UVD & Bay of Fundy, Canada & Martin et al. (1990) $)^{\mathrm{a}}$ \\
\hline & 0.221 & HPLC-FMOC & Limfjord, Denmark & Lundholm et al. (1997) \\
\hline & 0.01 & LC-MS/MS & Bahía Tongoy, Chile & Álvarez et al. (2009) \\
\hline & $\mathrm{nr}$ & HPLC-FMOC & Bizerte Lagoon, Tunisia & Sahraoui et al. (2009) \\
\hline & 0.0057 & cELISA & Chesapeake Bay, Maryland, USA & Thessen et al. (2009) \\
\hline \multirow[t]{3}{*}{ P. cuspidata } & 0.029 & cELISA & Offshore Washington State, USA & Auro (2007) \\
\hline & 0.019 & cELISA & Offshore Washington State, USA & Trainer et al. (2009a,b) \\
\hline & 0.031 & cELISA & Offshore Washington State, USA & Lundholm et al. (in press) \\
\hline \multirow[t]{3}{*}{ P. delicatissima } & 0.005 & HPLC-FMOC & Prince Edward Island, Canada & Smith et al. (1991) \\
\hline & 0.12 & ELISA & Blueskin Bay, New Zealand & Rhodes et al. (1998) \\
\hline & 0.0002 & $\mathrm{RBA}$ & Offshore Washington State, USA & Baugh et al. $(2006)^{b}$ \\
\hline \multirow[t]{3}{*}{ P. fraudulenta } & 0.03 & ELISA & Bay of Plenty, New Zealand & Rhodes et al. (1998) \\
\hline & $\mathrm{nr}$ & cELISA & Monterey Bay, California, USA & Wells et al. (2005) \\
\hline & 0.0008 & cELISA & Chesapeake Bay, Maryland, USA & Thessen et al. (2009) \\
\hline P. galaxiae & 0.00036 & LC-MS & Gulf of Naples & Cerino et al. (2005) \\
\hline P. granii & 0.000004 & cELISA & Ocean Station Papa, North Pacific & Trick et al. $(2010)^{c}$ \\
\hline \multirow[t]{27}{*}{ P. multiseries } & 21 & HPLC-FMOC & Prince Edward Island, Canada & Bates et al. (1989) \\
\hline & 9.6 & HPLC-FMOC & Prince Edward Island, Canada & Bates et al. (1991) \\
\hline & 5.0 & HPLC-FMOC & Prince Edward Island, Canada & Bates et al. (1993) \\
\hline & 12.5 & HPLC-FMOC & Prince Edward Island, Canada & Bates et al. (1996) \\
\hline & 18.99 & HPLC-UVD, FMOC & Wadden Sea, Holland & Vrieling et al. (1996) \\
\hline & 1.03 & HPLC-UVD & Jinhae Bay, South Korea & Lee and Baik (1997) \\
\hline & 67 & HPLC-FMOC & Prince Edward Island, Canada & Bates et al. (1999) \\
\hline & 46 & HPLC-FMOC & Prince Edward Island, Canada & Bates et al. (2001) \\
\hline & $\mathrm{nr}$ & HPLC-UVD & Les Glénan, Brittany, France & Amzil et al. (2001) \\
\hline & 2.4 & HPLC-FMOC & Chinhae Bay, South Korea & Cho et al. (2001) \\
\hline & 0.021 & HPLC-FMOC & Monterey Bay, California, USA & Maldonado et al. (2002) \\
\hline & 1.15 & HPLC-FMOC & Okkiray Bay, Japan & Lundholm et al. (2004) \\
\hline & 0.7 & HPLC-FMOC & Bay of Fundy, Canada & Lundholm et al. (2004) \\
\hline & 0.225 & ELISA & Offshore Washington State, USA & Wells et al. (2005) \\
\hline & 0.261 & RBA & Offshore Washington State, USA & Baugh et al. (2006) \\
\hline & $\mathrm{nr}$ & Mouse bioassay & Paranaguá State, Brazil & Mafra et al. (2006) \\
\hline & 0.006 & cELISA & Sequim Bay, WA & Radan (2008) \\
\hline & $140 ?$ & LC-MS/MS & Okkiray Bay, Japan & Trimborn et al. (2008) \\
\hline & 20.8 & HPLC-FMOC & Peter the Great Bay, Russia & Orlova et al. (2008) \\
\hline & 11.2 & RBA & Monterey Bay, California, USA & Doucette et al. (2008) \\
\hline & 0.80 & HPLC-UVD & Northland, New Zealand & Rhodes et al. (1998) \\
\hline & 5.0 & HPLC-UVD & Thames Estuary, UK & Calu et al. (2009) \\
\hline & 1.807 & cELISA & Chesapeake Bay, Maryland, USA & Thessen et al. (2009) \\
\hline & 23.6 & HPLC-UVD & Lisbon Bay, Portugal & Amorim et al. (2009) \\
\hline & 3.45 & LC-MS/MS & Coastal Brazil & Hagström et al. (2011) \\
\hline & 10 & cELISA & Eastern Canada & Sun et al. (2011) \\
\hline & 0.71 & cELISA & Eastern Canada & Guannel et al. (2011) \\
\hline \multirow[t]{4}{*}{ P. multistriata } & 0.645 & LC-MS & Gulf of Naples & Sarno and Dahlmann (2000) \\
\hline & 0.697 & LC-MS & Gulf of Naples & Orsini et al. (2002) \\
\hline & 0.28 & HPLC-FMOC & Gulf of Naples & Amato et al. (2010) \\
\hline & 0.04 & LC-MS & New Zealand & L. Rhodes (pers. comm.) \\
\hline \multirow[t]{2}{*}{ P. pseudodelicatissima } & $\mathrm{nr}$ & RBA & Northern Gulf of Mexico & Parsons et al. (1999) \\
\hline & 0.0078 & HPLC-UVD & Thermaikos Gulf, Greece & Moschandreou et al. (2010) \\
\hline \multirow[t]{4}{*}{ P. pungens } & 0.47 & HPLC-UVD & Marlborough Sounds, NZ & Rhodes et al. (1996) \\
\hline & 0.070 & HPLC-FMOC-RBA & Offshore Washington State, USA & Trainer et al. (1998) \\
\hline & 0.0018 & RBA & Coastal Washington State, USA & Baugh et al. (2006) \\
\hline & 0.2 & HPLC-UVD & Bay of Crozon, France & Calu et al. (2009) \\
\hline \multirow[t]{5}{*}{ P. seriata } & 33.6 & HPLC-FMOC & Nivå Bugt, Denmark & Lundholm et al. (1994) \\
\hline & 0.8 & HPLC-FMOC & St. Lawrence Estuary, Canada & Couture et al. (2001) \\
\hline & 7.0 & HPLC-FMOC & Gulf of St. Lawrence, Canada & Bates et al. (2002) \\
\hline & 14.7 & HPLC-FMOC & Lynn of Lorne, Scotland & Fehling et al. (2004b) \\
\hline & 1.93 & HPLC-FMOC & Nuuk (Godthåbsfjord), Greenland & Hansen et al. (2011) \\
\hline
\end{tabular}


Table 3 (Continued)

\begin{tabular}{|c|c|c|c|c|}
\hline Species & $\begin{array}{l}\text { Max DA concentration } \\
\left(\text { pg DA cell }{ }^{-1}\right)\end{array}$ & $\begin{array}{l}\text { DA quantitation } \\
\text { method used }\end{array}$ & Origin of isolate & Reference \\
\hline \multirow[t]{3}{*}{ P. turgidula } & 0.033 & HPLC-UVD & Tauranga Harbour, New Zealand & Rhodes et al. (1996) \\
\hline & 0.0000052 & cELISA & Ocean Station PAPA (NE Pacific) & Trick et al. (2010) \\
\hline & 0.09 & cELISA & Ocean Station PAPA (NE Pacific) & Bill (2011) \\
\hline P. sp. 233 & 13.48 & cELISA & Sequim Bay, WA, USA & Guannel et al. (2011) \\
\hline
\end{tabular}

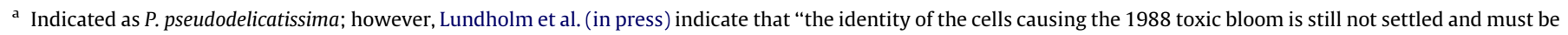
reconsidered".

b Belongs to the " $P$. delicatissima" complex.

c Shipboard batch culture of natural seawater containing P. granii as the only species of Pseudo-nitzschia.

d HPLC-ultra-violet detection.

e HPLC fluorenylmethoxycarbonyl derivative.

${ }^{f}$ Direct enzyme-linked immunosorbent assay.

g Liquid chromatograph-mass spectrometry.

h Tandem liquid chromatograph-mass spectrometry.

i Receptor binding assay.

j Competitive enzyme-linked immunosorbent assay.

$P$. delicatissima, $P$. fraudulenta and $P$. pungens, suggests the potential for harvesting closures.

\subsubsection{Argentina}

DA was recorded for the first time in the Argentine Sea in July 2000 , at Mar del Plata. The toxin was detected in plankton, mussels (M. edulis; $7.7 \mu \mathrm{g} \mathrm{DA} \mathrm{g}^{-1}$ ) and stomachs of anchovy (Engraulis anchoita; $76.6 \mu \mathrm{g} \mathrm{DA} \mathrm{g}^{-1}$ ), during a bloom of P. australis (Negri et al., 2004). There were no negative human health consequences during this, or any other subsequent events in Argentina (Ferrario et al., 2002). However, the presence of DA in the food web is cause for concern. As well, several other potentially toxic species are present along the Argentine coast and farther south, in the Drake Passage: $P$. multiseries, $P$. fraudulenta, $P$. pungens and $P$. turgidula (Negri and Inza, 1998; Ferrario et al., 2004; Almandoz et al., 2007).

The presence of $P$. pseudodelicatissima in Argentinean waters is not yet confirmed as species previously thought to be $P$. pseudodelicatissima are actually $P$. calliantha (Almandoz et al., 2007; Table 4). It should be noted that Almandoz et al. (2007) did not find $P$. seriata during their study, supporting Ferrario et al.
(2002), who considered the records of $P$. seriata in Argentinean waters to be a misidentification, and the identification should actually be $P$. australis. $P$. seriata has only been identified without doubt in cold to temperate waters of the Northern Hemisphere (Hasle, 1964; Hasle and Lundholm, 2005). However, P. seriata with only two rows of poroids was observed recently in samples from the Beagle Channel at the southernmost tip of South America (Almandoz et al., 2009; see also Hansen et al., 2011).

\subsubsection{Uruguay}

The only DA event reported for Uruguay was in mussels from Punta del Este, in December 2001, but toxicity ( $\left.9.9 \mu \mathrm{g} \mathrm{DA} \mathrm{g}^{-1}\right)$ was below the regulatory level; the toxin source was $P$. multiseries (Medina et al., 2003). The potentially toxic $P$. multistriata is also found in Uruguayan waters (Méndez and Ferrario, 2009).

\subsubsection{Brazil}

DA was not a human health problem in Brazil until January 2009, when toxin was reported in brown mussels (Perna perna; up to $20 \mu \mathrm{g} \mathrm{DA} \mathrm{g}^{-1}$ ) at two mussel farms in Santa Catarina State

Table 4

Amended identifications of Pseudo-nitzschia species. n.a.: not available.

\begin{tabular}{|c|c|c|c|}
\hline Original identification & Reference & Emended identification & Reference \\
\hline P. pseudodelicatissima & Martin et al. (1990) & $\begin{array}{l}\text { P. calliantha, } \\
\text { P. pseudodelicatissima or other }\end{array}$ & $\begin{array}{l}\text { Lundholm et al. (2003) } \\
\text { Kaczmarska et al. (2005), and } \\
\text { Lundholm et al. (in press) }\end{array}$ \\
\hline P. pseudodelicatissima & Hallegraeff (1994) & P. dolorosa & Jameson and Hallegraeff (2010) \\
\hline P. pseudodelicatissima & Lundholm et al. (1997) & P. calliantha & Lundholm et al. (2003) \\
\hline P. pseudodelicatissima & Davidovich and Bates (1998) & $\begin{array}{l}\text { P. calliantha and } \\
\text { P. pseudodelicatissima or } \\
\text { P. cuspidata }\end{array}$ & Lundholm et al. (2003) \\
\hline P. pseudodelicatissima & Rhodes et al. (1998) & n.a. & \\
\hline P. pseudodelicatissima & Parsons et al. (1999) & Unknown & Lundholm et al. (2003) \\
\hline P. pseudodelicatissima & Adams et al. (2000) & $\begin{array}{l}\text { P. pseudodelicatissima or } \\
\text { P. cuspidata }\end{array}$ & Bates and Trainer (2006) \\
\hline P. sp. cf. pseudodelicatissima & Pan et al. (2001) & $\begin{array}{l}\text { P. pseudodelicatissima or } \\
\text { P. cuspidata }\end{array}$ & Lundholm et al. (2003) \\
\hline P. pseudodelicatissima (NWFSC-047) & Stehr et al. (2002) & P. fryxelliana & Lundholm et al. (in press) \\
\hline P. cf. pseudodelicatissima & Baugh et al. (2006) & n.a. & \\
\hline P. pseudodelicatissima & Trainer et al. (2007) & P. pseudodelicatissima & Trainer et al. (2007) \\
\hline P. calliantha2 & Amato et al. (2007) & P. mannii & Amato and Montresor (2008) \\
\hline P. delicatissima del 1 & Amato et al. (2007) & P. arenysensis & Quijano-Scheggia et al. (2009b) \\
\hline P. turgidula & Hallegraeff (1994) & P. dolorosa & Lundholm et al. (2006) \\
\hline P. delicatissima & No known record & P. dolorosa and P. decipiens & Lundholm et al. (2006) \\
\hline P. pseudodelicatissima & Ferrario et al. (1999) & P. calliantha & Almandoz et al. (2007) \\
\hline P. calliantha2 & Amato et al. (2007) & P. mannii & Amato and Montresor (2008) \\
\hline P. delicatissima del1 & Amato et al. (2007) & P. arenysensis & Quijano-Scheggia et al. (2009b) \\
\hline P. pseudodelicatissima? & Leandro et al. (2010b) & P. hasleana & Lundholm et al. (in press) \\
\hline P. pseudodelicatissima-complex (Ner-D8) & Orive et al. (2010) & P. hasleana & Lundholm et al. (in press) \\
\hline P. calliantha (IEO-PS50V) & Penna et al. (2007) & P. hasleana & Lundholm et al. (in press) \\
\hline P. pseudodelicatissima (CAWB82) & Rhodes et al. (1998) & P. caciantha & L. Rhodes (pers. comm.) \\
\hline
\end{tabular}


(Fernandes and Brandini, 2010). This led to closure of the farms for 25 days (Table 2 ). The responsible organism was not given, but the following potentially toxic species are present in the region: $P$. australis, $P$. calliantha, $P$. linea, $P$. multiseries, $P$. fraudulenta, $P$. pungens var. pungens and $P$. pungens var. cingulata (Odebrecht et al., 2001; Fernandes and Brandini, 2010). Because P. australis was reported exclusively in May and July, and was also absent in Santa Catarina State during a later study (Fernandes and Brandini, 2010), it likely was not the source of DA. Rather, it may have been $P$. multiseries, $P$. calliantha (two morphotypes) or $P$. pungens, which were found in Santa Catarina only, and abundantly from November to February (Fernandes and Brandini, 2010). The potentially toxic $P$. brasiliana and toxic P. multistriata were also found farther north, in the state of Rio de Janeiro (Villac et al., 2004, 2005). The toxigenic $P$. seriata is also described in the state of Paraná, adjacent to the north of Santa Catarina State (Procopiak et al., 2006). However, because of the possible misidentification of this species in South America (see Ferrario et al., 2002 and Almandoz et al., 2007, above), it is possible that this was actually $P$. australis.

Earlier, in adjacent (to the north) Paranaguá State, during August 2002 to October 2003, no DA was detected in harvested mangrove mussels (Mytella guyanensis), despite the presence of $P$. multiseries, $P$. calliantha, and $P$. pungens, sometimes at elevated concentrations (Mafra et al., 2006). Furthermore, one isolate of $P$. multiseries produced DA in culture (Table 3). It was postulated that the cell toxicity was low, or that the cells accounted for only a small fraction of the mussels' food intake, therefore accounting for the low levels of toxin in the shellfish.

Because DA has already been demonstrated to toxify aquacultured mussels in Brazil, and several toxigenic and potentially toxic Pseudo-nitzschia spp. are present, the establishment of a monitoring program in the molluscan aquaculture sectors has been advocated (Mafra et al., 2006). Such a program is currently in effect only in the State of Santa Catarina, the main bivalve producer, where biweekly surveys of several potentially harmful microalgal species, including Pseudo-nitzschia spp., and their toxins are carried out in 40 bivalve culture locations (L. Mafra, pers. comm.).

\subsection{Australia}

Although there are toxigenic Pseudo-nitzschia species in Australian waters and traces of DA have been detected in molluscan shellfish, there have been no reported incidences of ASP in Australia (Lapworth et al., 2001; Takahashi et al., 2007). Toxic or potentially toxic species include: P. australis, P. calliantha, P. cuspidata, P. delicatissima (Lundholm et al., 2003; Jameson and Hallegraeff, 2010), P. galaxiae (Lundholm and Moestrup, 2002), P. multiseries (Lapworth et al., 2001; Jameson and Hallegraeff, 2010), P. pungens, $P$. fraudulenta (Takahashi et al., 2007) and P. multistriata (Jameson and Hallegraeff, 2010). Significant levels of DA (up to $500 \mathrm{ng} \mathrm{DA} \mathrm{ml}^{-1}$ ) were confirmed in $P$. australis cultures tested (Table 3), indicating a potential threat in Australian waters (Lapworth et al., 2001), although this has not yet been realized. $P$. multiseries is present less often, and only at low concentrations, and isolates have not yet been tested for toxicity, but isolates of $P$. pungens, and of the P. pseudodelicatissima-complex species, were nontoxic (Hallegraeff, 1994; Lapworth et al., 2001). Other nontoxic species include: $P$. americana, $P$. dolorosa, possibly $P$. heimii, $P$. lineola, $P$. subfraudulenta and possibly $P$. subpacifica (Hallegraeff, 1994; Lapworth et al., 2001; Jameson and Hallegraeff, 2010; G. Hallegraeff, pers. comm.).

\subsection{New Zealand}

Diatoms of the genus Pseudo-nitzschia have been observed in New Zealand's coastal waters for at least four decades, but no toxic species or DA contamination in bivalve shellfish were reported until 1993 (Rhodes et al., 1996), when phytoplankton and biotoxin monitoring programs were implemented. The first indication of toxicity was in November, 1993, in Whangaroa Harbour, when DA was found in the digestive gland of the New Zealand scallop (Pecten novaezealandiae; $270 \mu \mathrm{g} \mathrm{DA} \mathrm{g}^{-1}$ ) (Rhodes et al., 1996). That same year, toxins causing DSP, PSP and NSP, and their microalgal producers, were detected. There is no evidence that the considerable expansion in Greenshell ${ }^{\mathrm{TM}}$ mussel (Perna canaliculus) farming in the Marlborough Sounds (the major shellfish growing area) has resulted in any increased incidence of HABs (Rhodes et al., 2001). From then on, DA has been recorded in various shellfish species (Table 1).

The most detailed information on DA in aquacultured bivalves is given in Hay et al. (2000), but only for the years 1994-1999. Pseudo-nitzschia species and DA have been detected at all monitoring sites, on both the North and South Islands, although all closures of shellfish harvesting, except one (in the Marlborough Sounds aquaculture area), have occurred on the North Island. The highest level was $600 \mu \mathrm{g} \mathrm{DA} \mathrm{g}^{-1}$, in the digestive gland of Pecten novaezealandiae from Doubtless Bay, on November 1994. Only a low percentage of the commercially harvested bivalve samples had DA levels above the regulatory limit: $1.64 \%$ for scallops and $0.02 \%$ for Greenshell ${ }^{\mathrm{TM}}$ mussels. Two instances of DA above the limit for mussels were in Marlborough Sounds in December 1994 (187 $\mu \mathrm{g} \mathrm{DA} \mathrm{g}^{-1}$ ), and Houhora, in Northland (33 $\left.\mu \mathrm{g} \mathrm{DA} \mathrm{g}^{-1}\right)$.

In New Zealand, species of Pseudo-nitzschia that have been shown to produce DA in culture (Table 3 ) include: P. australis, $P$. multiseries, $P$. multistriata, $P$. pungens, $P$. fraudulenta, P. delicatissima, P. turgidula and P. pseudodelicatissima; $P$. cf. heimii was present at only low concentrations (Rhodes et al., 1996, 1998, $2000,2004)$. It should be noted that clarifications are still needed regarding the status of some species within the $P$. pseudodelicatissima and $P$. delicatissima complexes, and with $P$. cf. heimii; this is being accomplished with molecular data (L. Rhodes, pers. comm.).

\subsection{Africa}

\subsubsection{South Africa and Namibia}

Whereas several Pseudo-nitzschia spp. responsible for ASP are known to occur in the Benguela, for example $P$. australis (Marangoni et al., 2001), shellfish toxicity has yet to be recorded in this region (Pitcher and Calder, 2000). However, DA has recently been measured in seawater samples containing Pseudo-nitzschia cells, although the toxigenic species were not identified (Fawcett et al., 2007). This provided the first conclusive evidence for the presence of ASP toxins in the Benguela system. During this study, particulate DA concentrations derived from filtered plankton samples ranged from 0.1 to $3 \mu \mathrm{g} \mathrm{DA}{ }^{-1}$ and closely tracked the total cell concentrations of Pseudo-nitzschia species. In 2004, DA in phytoplankton (2-200 ng DA $^{-1}$ ) and the viscera of planktivorous pilchard (Sardina pilchardus; $120 \mathrm{ng} \mathrm{DA}^{-1}$ ) were found off the Namibian coast (D.C. Louw, B. Currie, G. Doucette, pers. comm.).

\subsubsection{Tunisia, Algeria and Morocco}

In northern Africa, bordering the Mediterranean Sea, several species of Pseudo-nitzschia have the risk of becoming problematic, although no instances of DA contamination have yet been reported. Bizerte Lagoon, northern Tunisia, is an important region for molluscan aquaculture that is particularly vulnerable. The bloom dynamics of several Pseudo-nitzschia species has been studied, and isolates of $P$. calliantha (Sahraoui et al., 2009) and $P$. brasiliana (Sahraoui et al., 2011) have been shown to produce DA (Table 3). Additional species reported include: $P$. pseudodelicatissima, P. multistriata, $P$. delicatissima-complex species and $P$. cf. seriata. 
In Algeria, there have been no reported incidences of DA contamination, although at least two toxigenic species are present: $P$. multiseries (Hasle, 2002) and P. calliantha (Illoul et al., 2008). On Morocco's Mediterranean coast, a bloom of Pseudo-nitzschia spp. coincided with the detection of low levels of DA in king scallops (Pecten maximus; $0.2 \mu \mathrm{g} \mathrm{DA} \mathrm{g}^{-1}$ ), but not in any other shellfish species (reported in Tahri-Joutei et al., 2003). Subsequent blooms of Pseudo-nitzschia spp. $\left(10^{4}\right.$ cells $\left.1^{-1}\right)$ occurred in February 1997 ,

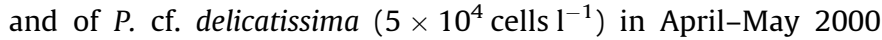
(Tahri-Joutei et al., 2003). On the Atlantic coast, potentially toxic Pseudo-nitzschia species include: $P$. australis, $P$. fraudulenta and $P$. pseudodelicatissima-complex species (Ennaffah, 2007).

\subsection{Asia}

Pseudo-nitzschia species have been documented in Vietnam, Japan, Korea and Russia, with P. pungens dominating in Korea, China and Russia. No human poisonings due to DA in shellfish have been reported in these countries (Skov et al., 2004; NOWPAP, 2005; Huang et al., 2009).

Significant levels of DA ( $145 \mu \mathrm{g}$ DA g ${ }^{-1}$ whole tissue) have been detected in the spiny oyster (Spondylus), collected from the Philippines and Vietnam (Dao et al., 2009). However, the responsible species of Pseudo-nitzschia have not yet been identified. The population dynamics of $P$. pungens was studied in Zhelin Bay, China in the early 2000s. In that study, an isolate of $P$. cf. pseudodelicatissima from Lampung Bay, China, showed no production of DA by HPLC-UV (Panggabean, 2007). Likewise, P. pungens, $P$. cuspidata, $P$. brasiliana, $P$. multistriata and $P$. multistriata isolated from the along Chinese coast did not show detectable DA by HPLCUV (R. Liu, pers. comm.).

In Russia, light and electron microscopical examination of 314 phytoplankton field samples, collected from 1995 to 2006, revealed the presence of eleven Pseudo-nitzschia species: P. americana, P. cf. caciantha, $P$. calliantha, $P$. delicatissima/arenysensis, $P$. fraudulenta, P. cf. heimii, P. multiseries, P. multistriata, P. obtusa, P. pungens and P. seriata (Stonik et al., 2011b). Blooms of $P$. calliantha, $P$. multiseries, $P$. multistriata and $P$. pungens have been observed in summer and autumn in Peter the Great Bay in the northwestern Sea of Japan, with abundances exceeding $10^{6}$ cells $1^{-1}$ and constituting $75-98 \%$ of the total density of the phytoplankton assemblage. The dominant species in the Sea of Okhotsk were $P$. pungens, $P$. calliantha and $P$. americana, with abundances exceeding $2 \times 10^{5}$ cells $^{-1}$ and constituting $30-75 \%$ of the total phytoplankton assemblage in summer and autumn (Stonik et al., 2011b).

DA was found for the first time in stationary-phase P. multiseries cells isolated from Peter the Great Bay, at concentrations varying between 180 and $5390 \mathrm{ng} \mathrm{DA} \mathrm{ml}^{-1}$ or $2-21 \mathrm{pg} \mathrm{DA} \mathrm{cell}^{-1}$ (Orlova et al., 2008; Table 3). No DA was detected $\left(<2 \mathrm{ng} \mathrm{ml}^{-1}\right)$ in cultures of $P$. calliantha and $P$. multistriata from the same locality. A gamma proteobacterium (tentatively identified as Alteromonas macleodii) was isolated from P. multiseries strain PM-02 (Orlova et al., 2008), and was earlier shown to significantly enhance the DA concentration of an axenic culture of P. multiseries (S.S. Bates, I. Kaczmarska, C. Léger, J. Ehrman and D.H. Green, unpubl. data). Concentrations of DA in tissues of the bivalves, Mytilus trossulus, Crenomytilus grayanus and Mizuhopecten yessoensis, from Peter the Great Bay, ranged from 0.01 to $0.5 \mu \mathrm{g} \mathrm{DA} \mathrm{g}^{-1}$, well below permissible regulatory limits (Stonik et al., 2011a).

\subsection{Europe}

During the last decade, it was realized that DA can also pose a problem in European shellfish. The toxin has now been detected in shellfish from many European countries, particularly UK, Ireland and France (EFSA, 2009). European strains of several Pseudo-nitzschia species have been found to be toxic: $P$. australis, $P$. calliantha, $P$. galaxiae, $P$. multiseries, $P$. multistriata, $P$. pseudodelicatissima, $P$. pungens and $P$. seriata (Table 3; Lundholm et al., 1994; Sarno and Dahlmann, 2000; Cusack et al., 2002; Orsini et al., 2002; Fehling et al., 2004a,b; Moschandreou et al., 2010; E. Keady, pers. comm.). DA has especially impacted scallop fisheries in European waters (EFSA, 2009), and accumulation and prolonged retention of DA has resulted in closures of harvesting in e.g. UK, Ireland (Bogan et al., 2007a,b), France (Nézan et al., 2006; Klein et al., 2010), Denmark (Lundholm et al., 2005a), Portugal (Vale and Sampayo, 2001) and Spain (Arévalo et al., 1998; Fraga et al., 1998) (Table 2; James et al., 2005). On average, $59 \%$ of scallops tested contained DA above the EU regulatory limit (EFSA, 2009). Particularly in Scotland, accumulation of DA resulted in long-term closures of scallop fisheries from the Scottish west coast (Gallacher et al., 2001; Smith et al., 2006). Since the EU directive for monitoring ASP in scallops changed in 2005, DA has not been a major problem in Scottish waters, as the processors now sell only the adductor muscle of the scallops (which is usually free of DA) and there are thus no closures of scallop harvesting areas (E. Bresnan, pers. comm.). DA in mussels, however, still results in short closures every year in Europe. There have not been any reported human illnesses associated with DA in Europe, but due to lack of a formal reporting system, mild cases could have gone un-noticed (EFSA, 2009).

Pseudo-nitzschia has been present in European waters for more than a century (e.g. Hasle et al., 1996; Churro et al., 2009; Lundholm et al., 2010) and is frequently reported as abundant or dominating in coastal areas in certain seasons (Fehling et al., 2004b, 2006; Zingone et al., 2006; Spatharis et al., 2007; Besiktepe et al., 2008; Quijano-Scheggia et al., 2008; Orive et al., 2010). There are few studies on long-term trends of occurrence of Pseudonitzschia. On the Atlantic coast of Spain, a weakening in the coastal upwelling was observed over the last two decades (Perez et al., 2010). In spite of a simultaneous increase in percentage of dinoflagellates, and a decrease in total diatoms, they found a highly significant increase in numbers of Pseudo-nitzschia spp. Sediment core studies are excellent for exploring long-term trends of occurrence and abundance of Pseudo-nitzschia. A sediment-core study in Mariager Fjord, Denmark, found no indication of an increase in the total relative abundance of Pseudo-nitzschia during the last hundred years (Lundholm et al., 2010). A similar study in the Gulf of Mexico revealed an increasing relative abundance of total Pseudo-nitzschia over time (Parsons et al., 2002).

Changes in species composition and distribution of Pseudonitzschia have been observed in Europe. In the Skagerrak, $P$. multiseries declined in abundance after the late 1960s and 1970s, when it was the predominant Pseudo-nitzschia species (Hasle et al., 1996). Since the early 1990s, it has been recorded less frequently in the Northern European coastal waters (Hasle et al., 1996; Hasle, 2002; Bresnan, 2003; Fehling et al., 2006; Lundholm et al., 2010). At the same time, $P$. pungens has changed from being observed mainly during autumn before 1986, to now occurring all year round (Hasle et al., 1996). In a study of sediment-cores spanning at least a 100 year period, a similar shift in relative species abundance of Pseudo-nitzschia was recorded, with $P$. multiseries being dominant before 1958 (making up $>90 \%$ of the Pseudo-nitzschia community), to $P$. pungens, especially, and recently also $P$. americana, dominating the Pseudo-nitzschia community (Lundholm et al., 2010).

Pseudo-nitzschia australis seems to have extended its distribution in Europe. Previously, P. australis was not recorded from Northern European waters (Hasle et al., 1996). Then, the sudden findings of $P$. australis in European waters in 1994-1995, in Galicia, northwest Spain (Miguez et al., 1996) and in 1999-2000, in Scottish waters (Gallacher et al., 2001), indicate a spreading of $P$. australis northward in Atlantic waters. Long-term studies are 
needed to confirm this. The distributional patterns of other Pseudonitzschia species are still not fully established.

\section{Molecular studies of Pseudo-nitzschia}

During the last decade, an increasing number of studies combining morphological and molecular characters for studying taxonomy and evolution of Pseudo-nitzschia have been published and species have been newly described or emended (e.g. Lundholm et al., 2003, 2006, in press; Amato et al., 2007; Amato and Montresor, 2008; Churro et al., 2009). This has revealed that cryptic and pseudo-cryptic species are a more commonly encountered phenomenon than previously considered (Orsini et al., 2004; Lundholm et al., 2003, 2006, in press; Amato et al., 2007; QuijanoScheggia et al., 2009b). Cryptic species are morphologically identical, but genetically different, whereas pseudo-cryptic species, apart from the genetic diversity, show minor morphological differences that are only detected by detailed examination (Mann and Evans, 2007). The description of cryptic and pseudo-cryptic species might appear to make species identification more cumbersome. However, correct species assignment provides a possibility for understanding complex patterns of physiological parameters, e.g. toxin production, biogeographical patterns and species succession in field studies. Species identification will become easier in the future with further developments of PCR tools, e.g. microarray or simpler methods like ARISA (Automated Ribosomal Intergenic Spacer Analysis) analyses (McDonald et al., 2007; Hubbard et al., 2008; Medlin and Kooistra, 2010; reviewed by Kudela et al., 2010). However, development of such molecular methods relies on a thorough understanding of the underlying taxonomy.

\subsection{Phylogeny}

Different regions of the genome have been targeted to assess the phylogeny of Pseudo-nitzschia: LSU, ITS1, 5.8S and ITS2 of the ribosomal DNA and rbcL, the large subunit of RuBisCo (Lundholm et al., 2002a,b, 2006; Orsini et al., 2004; Amato et al., 2007). The nuclear-encoded internal transcribed spacers (ITS), comprising ITS1, 5.8S and ITS2, have been the most widely used, as they give highly supported separation of species, and ITS2 is useful as a barcode sequence (Evans et al., 2007; Moniz and Kaczmarska, 2009). Furthermore, a correlation between mating compatibility and base changes in ITS2 makes the region a useful molecular tool. After sexual reproduction of Pseudo-nitzschia was first described (Davidovich and Bates, 1998), it then became possible to include mating compatibility in studies of taxonomic relatedness. Mating of strains has since been included in several phylogenetic studies (Amato et al., 2007; Casteleyn et al., 2008; Quijano-Scheggia et al., 2009b; Lundholm et al., in press). Another way of assessing mating compatibility is to explore the secondary structure of ITS2. The DNA strand of ITS2 folds to form a complex secondary structure with stems (pairings) and loops (no pairings), which play a role in the construction of ribosomes (Tschochner and Hurt, 2003). Base changes in both or one of the bases in the basepairs of the stems, known as CBCs (compensating base changes) and hemi-CBCs, respectively, have been found to correlate with mating compatibility of Pseudo-nitzschia strains. This finding supported Coleman's (2000, 2003, 2007, 2009) general observations of ITS2 and mating compatibility and makes ITS2 an excellent tool for studies of species delineation.

A number of species complexes have been identified in Pseudonitzschia, with the help of molecular tools. What were formerly regarded as $P$. pseudodelicatissima and $P$. cuspidata have now been shown to comprise the morphological, molecular and reproductively well-separated entities: P. calliantha, P. caciantha, P. mannii,
P. hasleana, P. fryxelliana and P. cuspidata/P. pseudodelicatissima (Table 4; Lundholm et al., 2003, in press; Amato et al., 2007; Amato and Montresor, 2008). However, there is still a taxonomic problem with P. cuspidata and P. pseudodelicatissima, as the only morphological difference between the two species is valve shape. Moreover, in all phylogenetic studies, P. pseudodelicatissima and $P$. cuspidata strains cluster within one highly supported clade (e.g. Lundholm et al., 2003, in press; Amato and Montresor, 2008; Moschandreou et al., 2010). Studies on the secondary structure of strains from the clade have revealed that $\mathrm{CBCs}$ and hemi-CBCs exist among the strains in the group (Amato et al., 2007; Moschandreou et al., 2010), but any subdivision of the clade is premature (Lundholm et al., 2003, in press; Amato and Montresor, 2008; Moschandreou et al., 2010). The type locality of P. cuspidata is Gran Canary (most closely represented by the strain "Tenerife8"), whereas the type locality of $P$. pseudodelicatissima is the subarctic Denmark Strait (Hasle, 1965), for which no strains are available. Future studies that include phylogenies on more genes, secondary structure analyses, mating studies comprising several strains, and inclusion of a strain of $P$. pseudodelicatissima from the type locality, are needed to finally settle the taxonomic problem.

Pseudo-nitzschia delicatissima has similarly been split into wellseparated pseudo-cryptic species: $P$. delicatissima, $P$. decipiens and $P$. dolorosa. However, it was recently recognized that $P$. delicatissima, as previously defined, actually consists of two separate clades, representing two cryptic species: $P$. delicatissima and $P$. arenysensis (Orsini et al., 2004; Lundholm et al., 2006; Amato et al., 2007; Quijano-Scheggia et al., 2009b). The two cryptic species are morphologically indistinct, but comparisons of the secondary structure of ITS2 support that the species are separate entities. Furthermore, the species differ with respect to physiological parameters, e.g. temperature required to sexualize the genotypes and differences in growth rates (Kaczmarska et al., 2008; QuijanoScheggia et al., 2009b).

Pseudo-nitzschia americana and the pseudo-cryptic P. brasiliana and $P$. linea also represent a morphological species complex (Lundholm et al., 2002b). P. americana had previously been observed only as epiphytic single cells, in contrast to other Pseudo-nitzschia species, but has now also been found forming the chains typical of Pseudo-nitzschia (Kaczmarska et al., 2005). Another unusual Pseudo-nitzschia species is P. galaxiae, which has a completely different stria structure than the other species. Therefore molecular data were important for assessing its phylogenetic relationship (Lundholm and Moestrup, 2002). It has been found with three different morphotypes in the Gulf of Naples, having the same ultrastructure, but differing in size (Cerino et al., 2005). The three morphotypes bloom at different times of the year (Cerino et al., 2005). Parallel analyses on ITS, rbcL and LSU showed a seasonal segregation among these distinct genotypes, which matched the succession of different size classes (McDonald et al., 2007).

The cosmopolitan $P$. pungens has been split into three variants, based on morphological, molecular and reproductive data: var. pungens, var. cingulata and var. aveirensis (Casteleyn et al., 2008; Churro et al., 2009). These represent two reproductively isolated groups. Although two of the variants ( $P$. pungens var. pungens and $P$. pungens var. aveirensis) are well-differentiated, occasional hybrids between the variants have been found in the field (Casteleyn et al., 2008; Holtermann et al., 2010), suggesting that they are not reproductively separated. This is supported by the analyses of the secondary structure of ITS2. Based on similar analyses of ITS2, it is hypothesized that the third variant ( $P$. pungens var. aveirensis) is reproductively isolated from the other two (Churro et al., 2009). Within the one variant ( $P$. pungens var. pungens), significant geographical population differentiation has been revealed on a global scale, with very restricted gene flow between the different 
geographical populations (Casteleyn et al., 2010). This finding demonstrates that geographic distances play a role in speciation, even in highly dispersal phytoplankton organisms in the ocean. It is thus an excellent example of how detailed knowledge of harmful species like Pseudo-nitzschia can be of general importance for our understanding.

The genus Pseudo-nitzschia harbors even more diversity than presently described, as morphological variation that does not agree with any present species description continues to be detected (e.g. Lundholm et al., 2003; Kaczmarska et al., 2005; Sahraoui et al., 2009; Lundholm et al., in press). Similarly, the intrageneric and intraspecific diversity has been found to be greater than presently recorded (Stehr et al., 2002; McDonald et al., 2007); sequencing of LSU rDNA of strains from coastal waters of Washington State showed the presence of new ribotypes in the P. pseudodelicatissima group (Stehr et al., 2002). Likewise, application of genus-specific primers for LSU rDNA to field samples from the Gulf of Naples revealed three new genotypes not corresponding to any described species (McDonald et al., 2007).

\subsection{Molecular tools}

Within the last decade, there have been advances in the development of molecular tools for identifying Pseudo-nitzschia species within mixed assemblages and for determining population structure for species of Pseudo-nitzschia. An automated ribosomal intergenic spacer analysis (ARISA) was developed by Hubbard et al. (2008) for the rapid identification of Pseudo-nitzschia species in environmental samples. Microsatellite markers have been developed for P. pungens (Evans and Hayes, 2004), P. multiseries (Evans et al., 2004), P. multistriata (Tesson et al., 2011), and $P$. australis (N.G. Adams, unpubl. data).

\subsubsection{ARISA}

The ARISA assay allows for rapid identification of Pseudonitzschia species in environmental samples, using PCR primers predicted to amplify ITS1 fragment lengths for 11 known and one unknown species of Pseudo-nitzschia based on sequences in GenBank. Hubbard et al. (2008) used the ARISA to analyze environmental samples from Vancouver Island, Canada and Puget Sound, WA, USA. They detected nine distinct fragment lengths in clone libraries derived from the environmental samples in which eight of the fragment lengths corresponded to nine known or putative Pseudo-nitzschia species. In addition to analyzing fragment size, the fragments from the clone libraries can also be sequenced in order to differentiate species or individuals within a species. Hubbard et al. (2008) defined different genotypes of a single species as those that had identical ITS1 fragment lengths but $<3 \%$ sequence diversity. Additionally, isolates with different ITS1 fragment lengths as well as sequence identity $<3 \%$ (excluding insertions/deletions) were defined as different species types. For example, while $P$. australis and $P$. seriata shared the same fragment length, the sequences of the ITS1 fragments for these two species are different (7.8\%), allowing for differentiation of the two species. The most frequently detected species within the clone library was $P$. pungens, which also had the greatest number of distinct genotypes (12).

Marchetti et al. (2008) used the ARISA to identify Pseudonitzschia species during an iron enrichment experiment in the northeast subarctic Pacific Ocean, near Ocean Station Papa. They compared the results from the ARISA (performed on bulk seawater samples) to clone libraries developed from the same samples. Their analysis detected seven different ITS1 variants. Two of the fragments detected corresponded to $P$. granii and $P$. heimii, while another fragment corresponded to an unidentified Pseudo-nitzschia species that was also present in clone libraries. The remaining four observed fragments were likely putative, unidentified Pseudonitzschia ITS1 variants that were not detected in the clone libraries.

The ARISA can be an effective and more rapid method for detecting and identifying Pseudo-nitzschia species in environmental samples than traditional microscopic approaches. However, the accuracy of ARISA depends upon a complete understanding of the underlying taxonomy and the acquisition of correct sequence information with confirmatory culture validation. The development of clone libraries is also necessary in order to differentiate between species and to determine genotypes within a species. The assay is limited in that it may identify fragments that correspond to sequences for Pseudo-nitzschia species or species types that have not been previously identified. Additionally, the PCR primers may amplify fragments for organisms other than Pseudo-nitzschia that have not previously been tested for cross reactivity.

\subsubsection{Microsatellite markers}

Microsatellite markers can be used to identify distinct populations of Pseudo-nitzschia species and to help determine if those populations are made up of cryptic species, different varieties of the same species, or contain hybrid forms of species varieties. Although microsatellite markers are powerful tools for analyzing populations of Pseudo-nitzschia species, they rely on isolates and culturing techniques that may introduce some bias, as analysis is performed only on those isolates that survive the culturing process.

Six polymorphic microsatellite markers were characterized by Evans and Hayes (2004) for P. pungens. A subsequent study by Evans et al. (2005) in the German North Sea, showed very high levels of genetic and clonal diversity along with weak temporal and spatial genetic structuring among 464 isolates genotyped from two locations $\sim 100 \mathrm{~km}$ apart. Evans et al. (2005) suggested that, given the low levels of genetic differentiation and the high level of genetic diversity in their samples, there were no major barriers to gene flow in the German North Sea and that the 464 isolates originated from a single large, well-mixed population.

A study by Casteleyn et al. (2009b) used the microsatellite markers developed by Evans and Hayes (2004) to examine the population structure of $310 \mathrm{P}$. pungens isolates from water bodies with varying environmental conditions in the Southern Bight of the North Sea. The results of Casteleyn et al. (2009b) were similar to those of Evans et al. (2005) in that their data revealed no significant population structuring. When Casteleyn et al. (2009b) expanded their analysis to include isolates from the German, French and Dutch parts of the North Sea, they still did not observe any significant spatial differentiation over an area of $\sim 650 \mathrm{~km}$. However, the analysis included relatively few isolates from the areas outside of the Belgian North Sea.

Adams et al. (2009) used microsatellite markers designed by Evans and Hayes (2004) to analyze the population structure of $P$. pungens from the Pacific Northwest (PNW) coast of the USA and to compare that to the North Sea $P$. pungens using a subset of the isolates from the Evans et al. (2005) and Casteleyn et al. (2009b) studies. Analysis of the PNW samples revealed an admixture of two distinct populations of $P$. pungens. When compared to the North Sea population, the two PNW populations were more different from each other than either PNW population was from the North Sea population. The two PNW populations likely were representative of $P$. pungens clades I (var. pungens) and II (var. cingulata) that were described by Casteleyn et al. (2008); further analyses on a subset of isolates from these populations supported this hypothesis (Casteleyn et al., 2009a).

Casteleyn et al. (2010) examined P. pungens var. pungens from various locations worldwide using the microsatellite markers characterized by Evans and Hayes (2004) and found significant geographical genetic structuring. Population structure analysis 
revealed six genetic clusters where some isolates showed a more admixed background (northeastern Atlantic) and some isolates clustered mainly according to geographic location (northwestern Atlantic and Pacific). Casteleyn et al. (2010) suggested that gene flow among populations of planktonic diatoms like $P$. pungens var. pungens can be restricted by oceanographic features such as fronts and oceanic gyres, as well as continental land masses, resulting in genetic divergence of populations.

Nine polymorphic microsatellite markers were developed by Evans et al. (2005) for P. multiseries. These markers were used to genotype 25 field isolates of $P$. multiseries as well as six of their descendants that were the products of mating experiments. Twenty-two of the field isolates were from eastern Canada, two from Europe and one from Russia. They found that 23 of the 25 field isolates were distinct and the Russian isolate was the most genetically distinct. Significant genetic differences were observed among isolates from eastern Canada; however, some of those isolates were capable of interbreeding. Evans et al. (2005) suggest that the significant differentiation between the Russian isolate and many of the Canadian isolates indicates that discrete populations of $P$. multiseries exist; however, more extensive sampling is necessary.

Recently, microsatellite markers have been characterized for $P$. multistriata (Tesson et al., 2011). The authors described PCR primers for seven polymorphic loci and used the primers to amplify the microsatellite loci in 66 isolates of $P$. multistriata collected in the Gulf of Naples, Italy, from three different time period ( 22 isolates each) in 2008 . Based on their results, all of the loci deviated from Hardy-Weinberg equilibrium and two loci showed a small excess of homozygosity. The authors propose to use these markers in future studies to identify natural populations, infer their dynamics over seasonal blooms, analyze genetic structure over spatial scales and track changes in genetic diversity across sexual reproduction events.

\section{Life stages - implications in bloom ecology}

Pseudo-nitzschia, like many pennate diatoms, can reproduce sexually (Geitler, 1935). Cells in clonal cultures of Pseudo-nitzschia gradually decrease in cell size over time and eventually die if they do not undergo sexual reproduction (also called auxosporulation) to regenerate their large cell size. This is due to vegetative cell division and splitting of the silicon frustule between two daughter cells. The halves of the frustule (thecae) fit together like a glass Petri dish, with the hypotheca slightly smaller than the epitheca. The daughter cell that receives the smaller of the two thecae produces a new hypotheca inside the first, larger epitheca. This cell is thus smaller than the initial parent cell. In this way, the average length (but not usually the width) of the cells gradually decreases until they become so small that the culture, and presumably natural populations, can no longer survive. However, if cells undergo sexual reproduction, the large cell size is restored.

A Pseudo-nitzschia cell becomes sexualized when cell length decreases below a threshold size, known as the first cardinal point (Geitler, 1935). In P. multiseries, this is $23 \%$ of the length of largest cells (Bates and Davidovich, 2002) and in P. multistriata it is 39-71\% (D'Alelio et al., 2009). Sexual reproduction must occur before the cells reach a minimum length, which is $\sim 30 \mu \mathrm{m}$ in $P$. multiseries (Bates and Davidovich, 2002), 19-80 $\mu \mathrm{m}$ in P. delicatissima (Amato et al., 2005) and 39-55 $\mu \mathrm{m}$ in P. multistriata (D'Alelio et al., 2009). During this size window, cultures of Pseudo-nitzschia can be mixed together to stimulate sexual reproduction. Pseudo-nitzschia is generally dioecious (heterothallic), meaning that male and female gametes are produced by separate clones. These "sexes" are referred to as mating types "+" and "-" in Pseudo-nitzschia (Chepurnov et al., 2005). However, monoecious (homothallic) reproduction has been reported in P. brasiliana (Quijano-Scheggia et al., 2009a).

Mating in Pseudo-nitzschia can be achieved simply by mixing clones of the same species, but of opposite sex. Clones must be in good physiological condition to undergo sexual reproduction. Thus, clones must be mixed during the exponential growth phase, which can be from 3 to $6 \mathrm{~d}$ after inoculation of a batch culture. Temperature is an important factor as different species mate at different temperatures (Kaczmarska et al., 2008; Quijano-Scheggia et al., 2009b). Clones must receive a sufficient amount of light during a $24 \mathrm{~h}$ period. A photoperiod length up to $16: 8 \mathrm{~L}: \mathrm{D}$, the maximum studied, increased gamete and auxospore production (Davidovich and Bates, 1998; Hiltz et al., 2000). These results suggest that parent cells must be healthy and photosynthesizing to produce energy for sexual reproduction.

Sexual reproduction has been described with photographic evidence and/or mating compatibility experiments in 14 species and one variety: P. subcurvata (Fryxell et al., 1991), P. multiseries (Davidovich and Bates, 1998; Kaczmarska et al., 2000), P. pseudodelicatissima (which may be $P$. calliantha; Lundholm et al., 2003; Davidovich and Bates, 1998), P. fraudulenta (Chepurnov et al., 2004), P. pungens (Chepurnov et al., 2005; Casteleyn et al., 2008), P. delicatissima (Amato et al., 2005, 2007; Kaczmarska et al., 2008; Quijano-Scheggia et al., 2009b), P. pseudodelicatissima sensu stricto (Amato et al., 2007), P. calliantha (Amato et al., 2007; Lundholm et al., in press), P. dolorosa (Amato et al., 2007), P. mannii (Amato and Montresor, 2008), P. brasiliana (Quijano-Scheggia et al., 2009a), P. multistriata (D'Alelio et al., 2009), P. arenysensis (QuijanoScheggia et al., 2009b), P. pungens var. aveirensis (Churro et al., 2009), P. australis (Holtermann et al., 2010) and P. cuspidata (Lundholm et al., in press).

Despite some differences in the time necessary to complete sexual reproduction, the mating process is similar in all Pseudonitzschia species tested. The first step in sexual reproduction is the pairing between parent cells of opposite sex (gametangiogamy). Two cells generally pair valve to valve, lying parallel with close alignment of the cells. The next stage is gametogenesis. The paired cells divide meiotically and the content of each cell is partitioned along the transapical plane to form spherical gametes, two per cell. These gametes are identical in appearance (isogamous) and nonflagellated, but the behavior of the gametes differs between sexes (physiological anisogamy). One cell produces two active gametes ("+", "male") and the other two passive gametes ("-", "female"). The frustules of both cells open, permitting the active gametes to enter and fuse with the passive gametes (plasmogamy). This is not always successful in both pairs of gametes or in all pairings of parent cells. When it is successful, fusion takes only 1-2 min. After gamete fusion, the resulting zygote expands to form a long auxospore (Fig. 2), inside of which the large initial cell is formed that then divides vegetatively and exits the auxospore. The entire process, from gamete production to formation of initial cells takes 2-4 d.

Preliminary work has shown an interesting relationship between epibiont bacteria and Pseudo-nitzschia sexual reproduction. Some axenic clones of $P$. multiseries would not undergo sexual reproduction until bacteria were reintroduced (Thompson, 2000). Other mixtures of axenic clones did undergo sexual reproduction, but it is possible that these were contaminated by bacteria. Further work is required to determine the role of bacteria in sexual reproduction in this species.

There is also evidence that a type of "pheromone" or other chemical is being produced by sexually active Pseudo-nitzschia. Filtrates of sexually reproducing clones induced higher gamete production in other clones, even in the absence of cells of the opposite mating type (Haché, 2000). These results suggest that a chemical signal may stimulate gamete production and perhaps 

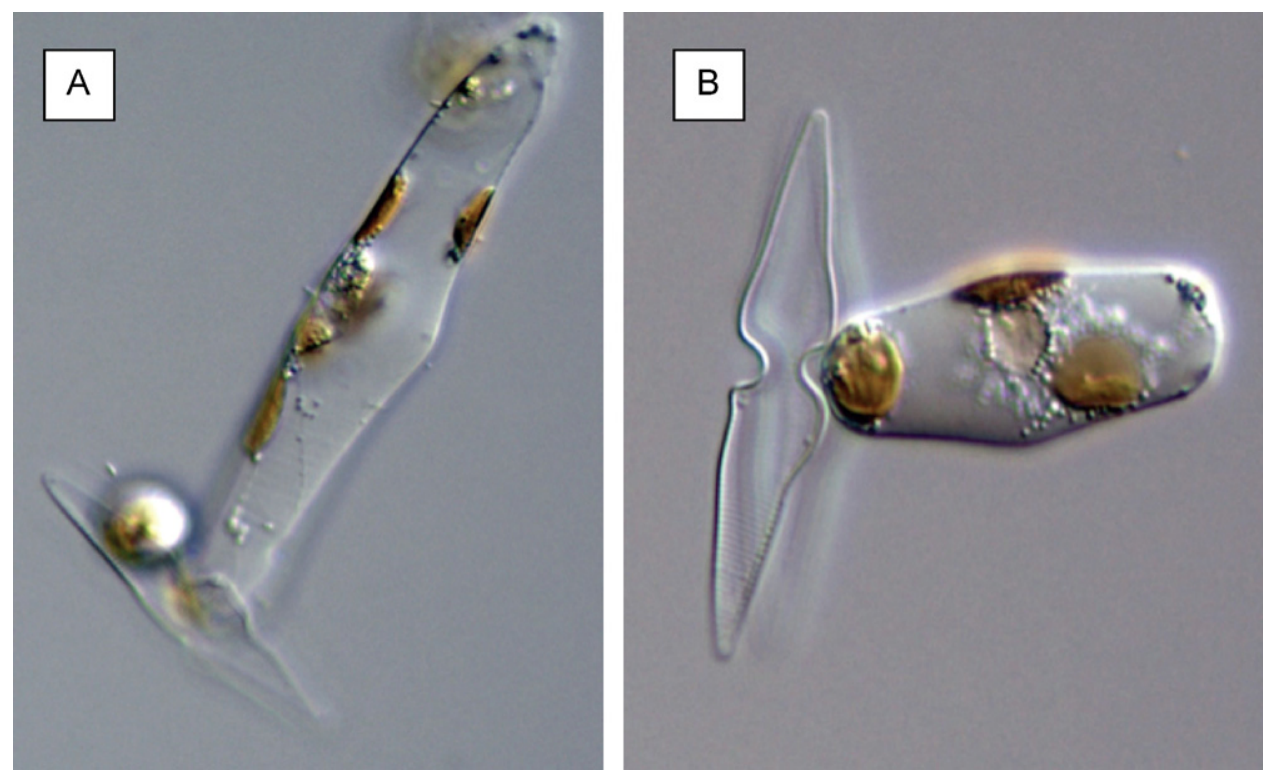

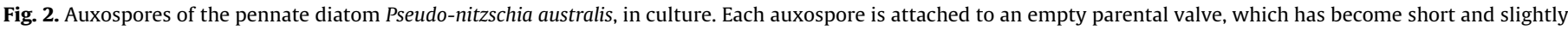

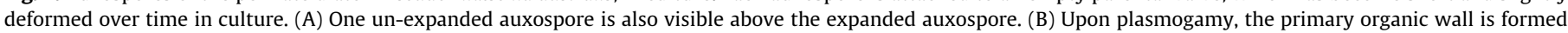

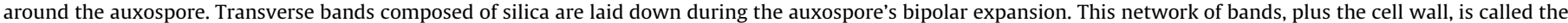
perizonium. A large initial cell is formed within the perizonium, restoring the large cell size of the diatom.

Reprinted with permission from J. Phycology (cover image, volume 46 (1), 2010, print version); photo credit: Karie Holtermann and E. Virginia Armbrust.

also synchronize gamete production in already sexualized cells. It is not known if such a signal would also assist cells of opposite sex to locate each other.

Sexual reproduction in Pseudo-nitzschia may be important for DA production. Clonal cultures of Pseudo-nitzschia decrease in size over time (see above), and also lose their ability to produce DA (Bates, 1998). However, when parental cells of $P$. multiseries that have lost their ability to produce DA are mated, their offspring can be toxic, sometimes even more so than their parents were initially (Bates et al., 1999; Lundholm et al., in press). Sibling clones can have significant variability in DA production, which could be accounted for by genetic differences or by the presence of different types and numbers of free-living or epibiont bacteria.

Information on environmental cues that induce sexual reproduction in diatoms in situ is almost nonexistent (Chepurnov et al., 2004). However, recent reports have documented the sexual reproduction in natural populations of $P$. cf. delicatissima and $P$. cf. calliantha in the Gulf of Naples, Italy (Sarno et al., 2010), and $P$. australis and $P$. pungens in coastal Washington State, USA (Fig. 1; Holtermann et al., 2010). Sex is likely not a rare event but may be constrained in time and may involve a very limited fraction of the population (Sarno et al., 2010), which may account for the scarcity of observation of sexual stages in nature. In the Gulf of Naples, during a bloom of both $P$. cf. delicatissima $\left(9.1 \times 10^{6}\right.$ cells $\left.\mathrm{I}^{-1}\right)$ and $P$. cf. calliantha $\left(7.0 \times 10^{6}\right.$ cells $\left.^{-1}\right)$ in September 2006 , only $9.2 \%$ and $14.3 \%$ of each species, respectively, were observed to undergo auxosporulation. Observations during the coastal Washington State Pseudo-nitzschia bloom (up to $9.3 \times 10^{5}$ cells l $^{-1}$ ) in June 2006, showed that auxosporulation began when the lowest size classes of both $P$. pungens and $P$. australis reached their maximum cell concentrations. In contrast to the bloom in Italy, the number of auxosporulating cells of $P$. australis exceeded the number of vegetative cells at the decline of the bloom. The highest rate of increase in auxosporulation and production of large new cells for both species occurred within a relatively narrow window of time and coincided with the decline in nutrients after the bloom had peaked (Holtermann et al., 2010). The significant relationship between the presence of large new cells resulting from auxosporulation and DA concentrations in razor clams at the coastal beach calls for further investigation.

\section{Nutritional physiology}

Despite the widespread interest in Pseudo-nitzschia and the potential environmental triggers of DA production, much of our understanding of the nutritional physiology of these toxigenic diatoms remains relatively unaltered from the seminal studies conducted by early investigators; their results have strongly influenced the interpretation of many field studies conducted in the past decade. Early studies reported on the relationship between growth rate and DA production, examined primarily with laboratory cultures of $P$. multiseries (reviewed by Bates, 1998; Bates and Trainer, 2006) and often extrapolated to other species. These demonstrated that DA production is usually minimal or nondetectable during exponential growth in batch cultures, and increases during the stationary phase as cell division slows as a result of either Si or P limitation. Similarly, studies have shown a reciprocal relationship between growth rate and DA production in Si- (Bates et al., 1996; Pan et al., 1996b; Kudela et al., 2004a) or Plimited continuous cultures of this species (Pan et al., 1996c; Hagström et al., 2011). An exception to the pattern of minimal or non-detectable DA during fast growth is $P$. cf. pseudodelicatissima (which may be P. cuspidata; Lundholm et al., 2003) from the Gulf of Mexico (Pan et al., 2001). Here, DA production and cellular DA concentrations were greatest when the growth rate was high and cell density was low during the early exponential phase, and no net DA production was determined during stationary phase. Other studies also have observed measurable levels of DA prior to the onset of stationary growth, e.g. in P. australis (Garrison et al., 1992), P. multiseries (Pan et al., 1996a; Radan, 2008; Thessen et al., 2009) and $P$. fraudulenta (Thessen et al., 2009). P. cuspidata even exhibited greater cellular DA in the exponential phase relative to stationary phase when $\mathrm{N}$, not $\mathrm{Si}$ or $\mathrm{P}$, was the macronutrient inducing the onset of stationary growth (Auro, 2007). These studies suggest that macronutrient stress (or limitation) and the resultant slowing of division rate, rather than cessation of cell growth, is the factor 
responsible for increased DA production (see also discussion in Section 6.4).

Field studies have also suggested that macronutrient limitation, most notably Si, as a possible trigger for DA production by Pseudonitzschia assemblages. During blooms of $P$. australis in coastal waters of the Southern California Bight, significant negative correlations were reported between cell abundance and particulate DA, and the ambient concentrations of silicic acid $\left(\mathrm{Si}[\mathrm{OH}]_{4}\right)$, nitrate $\left(\mathrm{NO}_{3}{ }^{-}\right)$and orthophosphate $\left(\mathrm{PO}_{4}{ }^{3-}\right.$ ) (Anderson et al., 2006; Schnetzer et al., 2007). In Los Angeles coastal waters, these, together with significant correlations between high cellular DA and both low $\mathrm{Si}[\mathrm{OH}]_{4}: \mathrm{PO}_{4}{ }^{3-}$ and $\mathrm{NO}_{3}{ }^{-}: \mathrm{PO}_{4}{ }^{3-}$ ratios (but not $\left.\mathrm{NO}_{3}{ }^{-}: \mathrm{Si}[\mathrm{OH}]_{4}\right)$, were interpreted as possible enhancement of DA production by P- or Si-limitation (Schnetzer et al., 2007). However, in the Santa Barbara Channel region, no significant relationships were observed for cellular DA and the absolute concentrations or ratios of nutrients. Nevertheless, the significant negative correlations between particulate DA and both the ratio of $\mathrm{Si}[\mathrm{OH}]_{4}: \mathrm{PO}_{4}{ }^{3-}$ and $\mathrm{Si}[\mathrm{OH}]_{4}: \mathrm{NO}_{3}{ }^{-}$, together with the observation of the highest cellular DA coincident with the lowest ambient $\mathrm{Si}[\mathrm{OH}]_{4}$ concentrations, led the authors to suggest that $\mathrm{Si}$ stress plays a role, albeit a complex one, in DA production by natural assemblages (Anderson et al., 2006). Such apparent enhancement of DA production, however, is not uniformly seen for all west coast North American Pseudo-nitzschia assemblages. Indeed, macronutrient-replete (including $\mathrm{Si}$ ) waters of the Pacific Northwest, including the well-known Juan de Fuca Eddy "hot spot", support healthy-growing Pseudo-nitzschia cells producing DA in the absence of measurable Si stress or limitation (e.g. Cochlan et al., 2006a,b; Marchetti et al., 2004; Trainer et al., 2009a).

Nitrogen, unlike $\mathrm{Si}$ or $\mathrm{P}$, is required for DA production (cf. review by Bates, 1998), and growth limitation by $\mathrm{N}$ is directly unfavorable for DA production in batch cultures of $P$. multiseries (Bates et al., 1991). However, measurable DA production has been observed under $\mathrm{N}$-limiting conditions in both continuous cultures of $P$. australis and $P$. multiseries (Kudela et al., 2004a; Radan, 2008; Hagström et al., 2011) and field assemblages of $P$. australis (Kudela et al., 2004b). There is increasing evidence that the $\mathrm{N}$ substrate fueling growth may influence both the exponential growth rate and the DA production rate achieved by various species of Pseudo-nitzschia, prior to either Si- or Pinduction of the stationary phase. Initial studies conducted by Bates et al. (1993) first demonstrated differential growth and toxin response to $\mathrm{N}$ substrates, where ammonium $\left(\mathrm{NH}_{4}{ }^{+}\right)$ concentrations of 220 and $440 \mu \mathrm{mol} \mathrm{N}$ promoted greater DA production than the same concentrations of $\mathrm{NO}_{3}{ }^{-}$during the stationary phase for two strains of $P$. multiseries, whereas at lower concentrations (110 and $55 \mu \mathrm{MN}$ ) the cell yield and DA production rates were equivalent for both $\mathrm{N}$ substrates. Recent studies have confirmed differential exponential growth rates as a function of $\mathrm{N}$ substrate for P. multiseries (Hillebrand and Sommer, 1996), P. australis isolates and field assemblages from Monterey Bay, CA (Cochlan et al., 2006a; Howard et al., 2007), and P. cuspidata from coastal Washington State (Auro, 2007). These studies also report that toxicity during the exponential phase was inversely related to growth rate; in other words the N substrate supporting the slowest growth (i.e. the least preferred $\mathrm{N}$ substrate; Dortch, 1990) will likely produce the most toxic (cellular DA) cells during exponential phase. However this trend is not uniform, as cultures of $P$. multiseries isolated from coastal Washington State (Sequim Bay) showed no such N preference for growth. Instead, they are consistently more toxic when grown on urea during $\mathrm{N}$-replete batch cultures and also in N-limited continuous cultures where their growth rate does not vary as a function of $\mathrm{N}$ source but rather is controlled by the dilution rate of the limiting N source (Radan, 2008).
Light, besides being required for the production of DA (Bates et al., 1991; Whyte et al., 1995), can also alter the $\mathrm{N}$ preference for growth, as initially reported for $P$. multiseries (Hillebrand and Sommer, 1996) and confirmed recently for P. cuspidata (Auro, 2007). Auro (2007) demonstrated that, for P. cuspidata grown at high light, neither cellular toxicity nor exponential growth rates showed a strong $\mathrm{N}$ preference for one $\mathrm{N}$ substrate over another, whereas at low light the slower $\mathrm{NO}_{3}{ }^{-}$-grown cells were significantly more toxic than $\mathrm{NH}_{4}^{+}$- or urea-grown cells, although urea supported the fastest growth. These more recent studies employed ecologically relevant $\mathrm{N}$ concentrations $(50-88 \mu \mathrm{M} \mathrm{N})$ and have confirmed differential growth as a function of $\mathrm{N}$ substrate, with the slower growing cells generally being the most toxic. However, interspecies differences and variability preclude any generalization attributable to the $\mathrm{N}$ substrate fueling growth rate or cellular toxicity.

Intrastrain variability has only recently been examined with respect to $\mathrm{N}$ use and the resulting toxicity, in studies using two strains of $P$. multiseries, five of $P$. fraudulenta and two of $P$. calliantha, isolated from the mid-Atlantic coastal region of the U.S. (Thessen et al., 2009). Here, the only observable trends were higher growth rates achieved on ammonium and lower growth rates on urea, for 8 of 9 strains tested. However, toxicity (measured as total DA, particulate DA and dissolved DA), examined during Si-induced stationary phase, showed no consistent pattern with respect to $\mathrm{N}$ source or relationship to the prior exponential growth. An exception was for two strains of $P$. multiseries that reached the highest toxin content at the highest growth rate. Based on results to date, it is clear that the $\mathrm{N}$ substrate affects DA production in addition to its direct effect on growth. Still, neither specific growth rate nor toxin content (in either exponential or stationary phase) can be consistently predicted as a function of $\mathrm{N}$ substrate due to species and strain variability in this genus.

The significance of dissolved organic N (DON) sources, other than urea, for the growth of Pseudo-nitzschia species is still unclear. Studies have demonstrated that $P$. multiseries is able to grow equally well using glutamine or nitrate (Hillebrand and Sommer, 1996). The same species was suggested to use glutamine and glutamate as a dark survival strategy (Mengelt, 2005), and glutamine was used at a rate equivalent to that of $\mathrm{NH}_{4}{ }^{+}$by $P$. australis, based on short-term uptake kinetic experiments (Cochlan et al., 2008). See Table 5 for a summary of species-specificity for growth under different nitrogenous nutrients. Enrichment experiments conducted with natural assemblages from the Mediterranean Sea (Loureiro et al., 2009a) and cultures of $P$. delicatissima (Loureiro et al., 2009b), isolated from coastal Spain, showed that in low inorganic $\mathrm{N}$ environments, high molecular-weight dissolved organic matter enrichment can contribute positively to the growth of $P$. delicatissima and Pseudo-nitzschia assemblages; this has been suggested as the "missing" nitrogenous source for sustenance of Pseudo-nitzschia during periods of depleted reserves of inorganic N. The effects of DON on DA production have not been studied to date.

\section{Ecology and nature of Pseudo-nitzschia harmfulness}

\subsection{Food web aspects and potential ecological disruptions}

As a diatom, Pseudo-nitzschia is an important primary producer at the base of the food web. It is consumed directly by a wide variety of organisms, from heterotrophic dinoflagellates to planktivorous fish (Table 1). As a hydrophilic molecule, DA does not bioaccumulate. Instead, DA is concentrated in the digestive system by filter feeding, with little transfer to surrounding tissues and in most cases quickly eliminated from the body. The toxin is moved through the food chain during blooms when primary consumers with guts full of Pseudo-nitzschia are eaten by 
Table 5

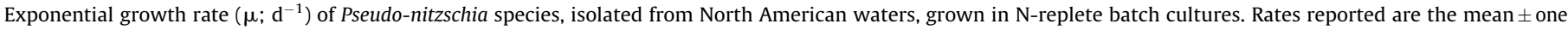
standard deviation (SD).

\begin{tabular}{|c|c|c|c|c|c|c|c|}
\hline Species & $\mathrm{N}$ conc. $(\mu \mathrm{M} \mathrm{N})$ & $\mathrm{PPFD}^{\mathrm{a}} / \mathrm{L}$ :D cycle & $\mathrm{NO}_{3}{ }^{-}$ & $\mathrm{NH}_{4}^{+}$ & Urea & Origin of isolate & Reference \\
\hline \multirow[t]{2}{*}{ P. calliantha } & 88 & $150-200 / 14: 10$ & $0.55 \pm 0.047$ & $0.87 \pm 0.154$ & $0.42 \pm 0.056$ & Choptank R., MD & Thessen et al. (2009) \\
\hline & & & $0.72 \pm 0.071$ & $0.71 \pm 0.064$ & $0.44 \pm 0.028$ & Asilomar, CA & \\
\hline \multirow[t]{5}{*}{ P. fraudulenta } & 88 & $150-200 / 14: 10$ & $0.75 \pm 0.051$ & $0.62 \pm 0.038$ & $1.02 \pm 0.137$ & Assateague I., MD & Thessen et al. (2009) \\
\hline & & & $0.84 \pm 0.035$ & $0.85 \pm 0.058$ & $0.58 \pm 0.067$ & Assateague I., MD & \\
\hline & & & $0.73 \pm 0.036$ & $1.22 \pm 0.177$ & $0.55 \pm 0.103$ & Assateague I., MD & \\
\hline & & & $0.75 \pm 0.039$ & $0.88 \pm 0.048$ & $0.58 \pm 0.181$ & Assateague I., MD & \\
\hline & & & $1.05 \pm 0.033$ & $1.16 \pm 0.020$ & $1.05 \pm 0.030$ & Asilomar, CA & \\
\hline \multirow[t]{5}{*}{ P. multiseries } & 88 & $150-200 / 14: 10$ & $0.65 \pm 0.018$ & $0.61 \pm 0.054$ & $0.68 \pm 0.070$ & Eastern Canada & Thessen et al. (2009) \\
\hline & 88 & $150-200 / 14: 10$ & $0.76 \pm 0.104$ & $0.76 \pm 0.175$ & $0.30 \pm 0.100$ & Choptank R., MD & Thessen et al. (2009) \\
\hline & $42-51$ & $120 / 24: 0$ & $0.85 \pm 0.028$ & $0.83 \pm 0.028$ & $0.81 \pm 0.071$ & Sequim Bay, WA & Radan (2008) \\
\hline & 200 & $230 / 14: 10$ & $0.49 \pm 0.063$ & No growth & - & Canada & Hillebrand and \\
\hline & 200 & $25 / 14: 10$ & $0.54 \pm 0.170$ & $0.35 \pm 0.021$ & $0.56 \pm 0.057^{c}$ & $\mathrm{PEI}^{\mathrm{b}}$, Canada & Sommer (1996) \\
\hline P. australis & 50 & $100 / 12: 12$ & $0.89 \pm 0.077$ & $0.93 \pm 0.001$ & $0.52 \pm 0.099^{d}$ & Monterey Bay, CA & Howard et al. (2007) \\
\hline \multirow[t]{2}{*}{ P. cuspidata } & 40 & $120 / 24: 0$ & $0.88 \pm 0.01$ & $0.91 \pm 0.02$ & $0.84 \pm 0.03$ & Offshore Washington State & Auro $(2007)^{\mathrm{e}}$ \\
\hline & 40 & $40 / 24: 0$ & $0.55 \pm 0.01$ & $0.51 \pm 0.02$ & $0.65 \pm 0.003$ & & \\
\hline
\end{tabular}

a Photosynthetic photon flux density (PPFD) measured in $\mu \mathrm{mol}$ photons $\mathrm{m}^{-2} \mathrm{~s}^{-1}$

b Prince Edward Island

c Growth on glutamine $=0.74 \pm 0.127 \mathrm{~d}^{-1}$.

d Incorrect SD provided in Howard et al. (2007).

e Standard error reported for rates determined from replicate cultures $(n=4)$.

secondary consumers. DA is eventually depurated, but depuration rates can vary, from hours in the blue mussel (M. edulis), Mediterranean cockle (Acanthocardia tuberculatum) and Greenshell ${ }^{\mathrm{TM}}$ mussel (Perna canaliculus), to several days in the Mediterranean mussel (M. galloprovincialis) and eastern oyster (Crassostrea virginica) (Novaczek et al., 1992; Wohlgeschaffen et al., 1992; Mackenzie et al., 1993; Vale and Sampayo, 2002; Mafra et al., 2010a). Three bivalves that are very slow to depurate are the razor clam Siliqua patula ( $>86$ days), the scallop P. magellanicus $(>14$ days) and the scallop Pecten maximus ( $\sim 416$ days) (Wohlgeschaffen et al., 1992, 1993; Douglas et al., 1997; Blanco et al., 2002).

DA may accumulate in organisms other than by filter feeding. Scavengers and deposit feeders have also been found to contain DA (Powell et al., 2002; Goldberg, 2003). Scavengers could become contaminated by eating DA-contaminated remains. Deposit feeders could become contaminated by consuming flocs of Pseudo-nitzschia that sink to the benthos at the end of a bloom (Goldberg, 2003). Some carnivores, like the swimming crab (Polybius henslowii), can contain high levels of DA but there have been no recorded incidents of poisoning in their predator, the yellow-legged gull (Larus cachinnans) that feeds on them almost exclusively (Álvarez, 1968; Munilla, 1997; Costa et al., 2003). Vertical flux of DA to the sediment appears to be a substantial source of toxin to the benthic food chain (Sekula-Wood et al., 2009, 2011) as DA is stable when adsorbed onto sediments (Burns and Ferry, 2007), long after Pseudo-nitzschia blooms have dissipated in the upper water column. There may be a limit in the number of trophic transfers over which DA can still be present at high enough concentrations to cause a toxic event. To date, all recorded ASP events have involved only three trophic levels: the diatom Pseudonitzschia, a bivalve or a planktivorous fish, and a human, marine mammal or marine bird. Interestingly, most cases of three-tiered trophic transfer have been recorded on the west coast of North America and Europe, and none were reported in the massive events in the southern Gulf of St. Lawrence in 1987 and 2002.

\subsection{Ecological profile of Pseudo-nitzschia species}

Blooms of Pseudo-nitzschia happen relatively frequently, in some regions seasonally, and in a wide variety of locations. In culture, Pseudo-nitzschia spp. can grow at salinities as low as 6 and as high as 48 , and at temperatures as low as $5^{\circ} \mathrm{C}$ and as high as $30^{\circ} \mathrm{C}$, with a broad range for optimum growth (Miller and
Kamykowski, 1986; Jackson et al., 1992; Lundholm et al., 1997; Cho et al., 2001; Thessen et al., 2005). However, different species in natural populations can demonstrate distinct correlations with environmental characteristics, which suggests seasonal succession of species or regional specificity (Fryxell et al., 1997). In the South China Sea, $P$. pungens peaks in April, May and June, $P$. multistriata is present only in spring and $P$. sinica and $P$. subpacifica are found in late fall and early winter (Qi et al., 1994). In addition, P. pungens in the colder $\left(1-10^{\circ} \mathrm{C}\right)$ waters of the North China Sea is present only in winter and spring, whereas $P$. pungens in the warmer $\left(21-29^{\circ} \mathrm{C}\right)$ East and South China Seas is present year round, revealing two ecotypes (Zou et al., 1993). Many species may coexist, but different growth and loss rates can lead to complex bloom dynamics and seasonal succession.

Pseudo-nitzschia blooms can be stimulated by nutrients from several sources, including upwelling or mixing events and riverine inputs. Both sources stimulate Pseudo-nitzschia blooms at concentrations of 8-22 $\mu \mathrm{M} \mathrm{NO}_{3}{ }^{-}, 2.4-35 \mu \mathrm{M}$ Si and 0.2-2 $\mu \mathrm{M} \mathrm{PO}_{4}{ }^{3-}$ (Dortch et al., 1997; Scholin et al., 2000; Trainer et al., 2000; Loureiro et al., 2005), but in different temperature and salinity regimes. Pseudo-nitzschia abundances and DA concentrations on the west coast of the U.S. are associated with low temperature, high salinity and high nutrient conditions typical of upwelling (Villac, 1996; Trainer et al., 2000, 2002). Similarly, upwelling regions off the coast of Portugal contain high numbers of Pseudonitzschia cells, which are used as upwelling indicators during spring and summer (Moita, 2001; Loureiro et al., 2005).

Riverine inputs have stimulated toxic Pseudo-nitzschia blooms in many regions and are characterized by lower salinities and higher temperatures than upwelling zones (Smith et al., 1990; Horner and Postel, 1993; Dortch et al., 1997; Trainer et al., 1998; Scholin et al., 2000; Spatharis et al., 2007; Kudela et al., 2008). A distinction between nutrients in upwelling and river plumes is that riverine inputs are likely the result of anthropogenic nutrient loading, including agricultural runoff and sewage. Sedimentological data show an increase in Pseudo-nitzschia abundance in the Mississippi River plume since 1950, suggesting a response to eutrophication (Parsons et al., 2002). However, in addition to an increase in nitrogen and phosphorus, nutrient ratios in Mississippi River water have also changed, i.e. the Si:N ratio has decreased (Turner and Rabalais, 1991), which favors Pseudo-nitzschia growth in culture (Sommer, 1994). Other river systems have also affected Pseudo-nitzschia abundances. When the mouth of the Yellow River 
A $\mathrm{B}$

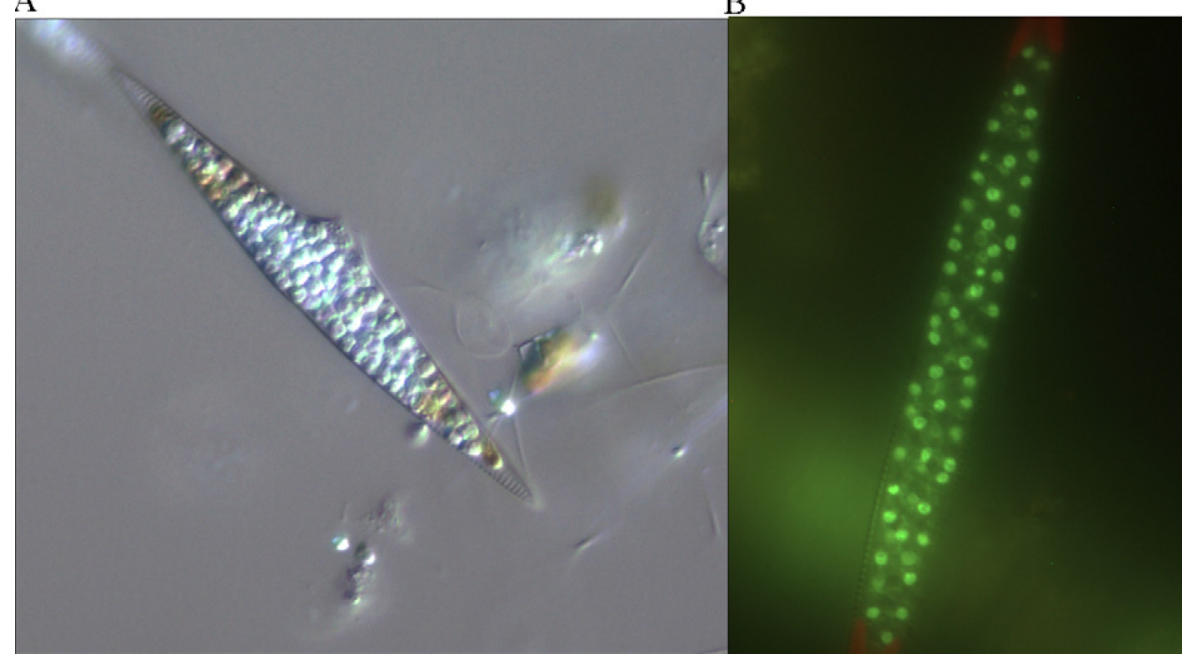

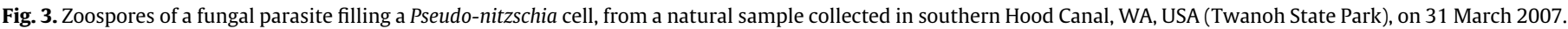

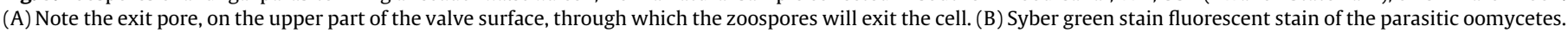
Photomicrographs courtesy of Karie Holtermann and E. Virginia Armbrust.

in China was artificially redirected in 1976, the location of the Pseudo-nitzschia bloom abruptly changed to follow the river plume (Zou et al., 1993). Pseudo-nitzschia abundance in the plume of the Yangtze River was positively correlated to $\mathrm{NO}_{3}{ }^{-}$and $\mathrm{PO}_{4}{ }^{3-}$ concentrations (Zou et al., 1993). In the South China Sea, Pseudo-nitzschia abundances responded to increased land runoff after rainfall (Qi et al., 1994) and in the Aegean Sea, Greece, a winter bloom of $P$. calliantha appeared to be induced by agricultural runoff shortly after a strong rainfall event (Spatharis et al., 2007). An analysis of $P$. delicatissima and $P$. pseudodelicatissima dynamics and environmental parameters in the Bay of Fundy, Canada, showed a strong relationship between $\mathrm{NO}_{3}{ }^{-}$and $\mathrm{NO}_{2}{ }^{-}$concentrations and the abundance of these species (Kaczmarska et al., 2007). These coastal studies show a response to riverine nutrients, changing nutrient ratios and eutrophication.

Much of the seasonal variability in Pseudo-nitzschia abundance can be explained by regular shifts in wind, irradiance, temperature and river flow. In the northern Gulf of Mexico, Pseudo-nitzschia abundance peaked in spring, corresponding to the average maximum in river flow, with another small peak in fall during wind events that mixed the stratified water column (Dortch et al., 1997). Many Pseudo-nitzschia blooms occur in the spring and fall, when irradiance is relatively low (Parsons et al., 1998; Mercado et al., 2005). In culture, P. multiseries can outcompete other phytoplankton species at low irradiance with a short photoperiod (Sommer, 1994). However, low light may contribute to the demise of autumn blooms (Bates et al., 1998). Day length can affect sexual reproduction (Hiltz et al., 2000), growth rates, cell yield, toxin production and influence which species of Pseudo-nitzschia becomes dominant (Fehling et al., 2005).

Local meteorological phenomenon, such as winds and heavy rainfall events, can stimulate Pseudo-nitzschia blooms. Wind events can be especially important for transporting toxic blooms inland from upwelling sites offshore (Trainer et al., 2000, 2002) or providing mixing necessary to bring nutrients into the photic zone (Lund-Hansen and Vang, 2004). Heavy rainfall after a drought can cause a dramatic increase in toxic Pseudo-nitzschia abundances in the river outflow, such as in eastern Canada in 1987 (Bates et al., 1998).

Larger scale changes in weather, such as the El Niño Southern Oscillation (ENSO), can affect Pseudo-nitzschia abundances by controlling upwelling near the west coast of the U.S. During weak ENSO years, upwelling is high and therefore so are Pseudo-nitzschia abundances (Fryxell et al., 1997). However, Pseudo-nitzschia can still bloom by taking advantage of other favorable events, such as increased runoff after rainfall, during strong ENSO years. Both 1991 and 1998, years with large toxic events on the west coast of the U.S., were strong ENSO years.

The decline of Pseudo-nitzschia blooms is less studied than its initiation. Parasitic fungi may play an important role in the demise of Pseudo-nitzschia blooms (Bates et al., 1998). Parasitic oomycetes and chytrids have infected $P$. pungens in eastern Prince Edward Island, Canada (Hanic et al., 2009). Additionally, fungal parasites have been observed in cells during bloom decline in coastal Washington, USA (Fig. 3; Horner et al., 1996) and an unexpected decrease in $P$. multiseries abundance in the Skagerrak between 1991 and 1993 was suspected to be caused by parasitic fungi (Hasle et al., 1996). Viruses are known to infect marine diatoms (e.g. Nagasaki et al., 2005), but studies on viral infections in Pseudonitzschia are just beginning (Carlson et al., 2009). High pH, resulting from dense blooms, could also lead to bloom decline. Laboratory cultures of several Pseudo-nitzschia species could not continue exponential growth at pH from 8.7 to 9.3 (Lundholm et al., 2004). The exact mechanisms of Pseudo-nitzschia bloom decline are uncertain and could be caused by multiple factors.

\subsection{Allelopathy}

Allelopathic effects, i.e. inhibitory effects on the growth of competitors caused by production of certain allelopathic substances, are known from prymnesiophytes and dinoflagellates and this may contribute to their ability to form monospecific blooms (Arzul et al., 1993; Granéli and Johansson, 2003). Pseudo-nitzschia species are also known to form dense blooms $\left(10^{6}\right.$ to $10^{8}$ cells $\left.1^{-1}\right)$, which are often more or less monospecific, accounting for up to $99 \%$ of the total phytoplankton and sometimes lasting for a long time, up to two months (e.g. Bates et al., 1989; Martin et al., 1990; Fryxell et al., 1997; Gallacher et al., 2001). It is known that DA leaks, or is actively transported, out of the cells, resulting in high levels of the toxin in the surrounding medium (reviewed by Bates, 1998; Wells et al., 2005). It is therefore reasonable to speculate that this toxin could have an allelopathic effect. Mixed culture experiments, however, showed no allelopathic effects of toxic P. multiseries on Chrysochromulina ericina, Heterocapsa triquetra, Eutreptiella gymnastica or Rhodomonas marina (Lundholm et al., 2005b). Similarly, additions of DA alone to the water had no allelopathic effects on 11 
different phytoplankton organisms (Windust, 1992; Lundholm et al., 2005b). Thus, there is still no evidence that allelopathic effects are likely to contribute to the formation of long-lasting Pseudo-nitzschia blooms, or serve as an explanation for the evolution of DA production.

\subsection{The ecological role of DA production}

The ecological position of Pseudo-nitzschia is in part related to its ability to produce DA. While most studies on DA production are focused on the harmful effects and gross levels of DA produced, the possible role of DA in the intracellular regulation of Pseudonitzschia physiology has also been considered. The molecular structure of DA evokes the possibility that this ecological toxin could serve as an iron or copper chelator for Pseudo-nitzschia. Significant findings by Rue and Bruland (2001) documented that the high stability constants of copper and iron to DA may provide an important ecological role as an iron-siderophore, keeping iron soluble and bioavailable in the environment for retrieval by Pseudo-nitzschia, or as a means of copper detoxification. Thus, they opened the idea that certain trace metals are critical to the ecological success of DA-producing species.

The physiological role of DA was further documented in Maldonado et al. (2002) and Wells et al. (2005). Maldonado et al. (2002) reported that DA production was inversely related to cellular growth rates when cells were limited by low iron or copper availabilities. While the cellular levels of DA increased, there was an additional increase in the levels of dissolved DA under metal stressed conditions; with up to $95 \%$ of the DA actively released into the environment. The presence of DA in the medium enhanced iron transport into low-iron grown cells. Further to this study, Wells et al. (2005) confirmed that DA is a functional component of the unusual high-affinity copper-regulated, iron acquisition system in Pseudo-nitzschia spp. They proposed that in the absence of an adequate copper supply, iron-limited natural populations of Pseudo-nitzschia will become increasingly toxic, and conversely, the production of DA will provide the Pseudo-nitzschia cells with a distinct ecological advantage. The cellular model of DA production, retention and release (Fig. 4; Wells et al., 2005) provides the backdrop for understanding the ecological dynamics of DA, where specific conditions are required to evoke the production of DA, the storage as particulate $\mathrm{DA}(\mathrm{pDA})$ and the release as dissolved DA (dDA).

It should be noted that the degree of iron stress experienced by the cells may be important in determining the response of Pseudonitzschia cells to iron. This may explain the contrary findings of the above studies and those of Bates et al. (2002), who reported that DA production decreased, rather than increased, as a result of depriving them of iron. The cells used by Maldonado et al. (2002) and Wells et al. (2005) were growing exponentially in semicontinuous cultures, and it could be argued that they were therefore less stressed by iron (="iron depleted"), whereas those used by Bates et al. (2002) were in stationary phase and therefore more highly stressed by iron (="iron limited"). With "iron limitation", less iron is available for chlorophyll synthesis and nitrogen metabolism, two processes that are necessary for maintaining elevated levels of DA production (Bates et al., 2002). This would not be the case with "iron-depleted" cells, which might then have a greater ability to produce DA.

The relationship between DA production and the ecological mosaic of coastal waters has been considered (Trainer et al., 2002, 2009a,b, 2010; Marchetti et al., 2004; MacFadyen et al., 2008). Trainer et al. (2009a) summarized the findings from a 6-cruise, 4year study at the Juan de Fuca eddy - a region off Washington State (USA) and British Columbia (Canada) that has a long history of DA production. They concluded that while Pseudo-nitzschia spp. at

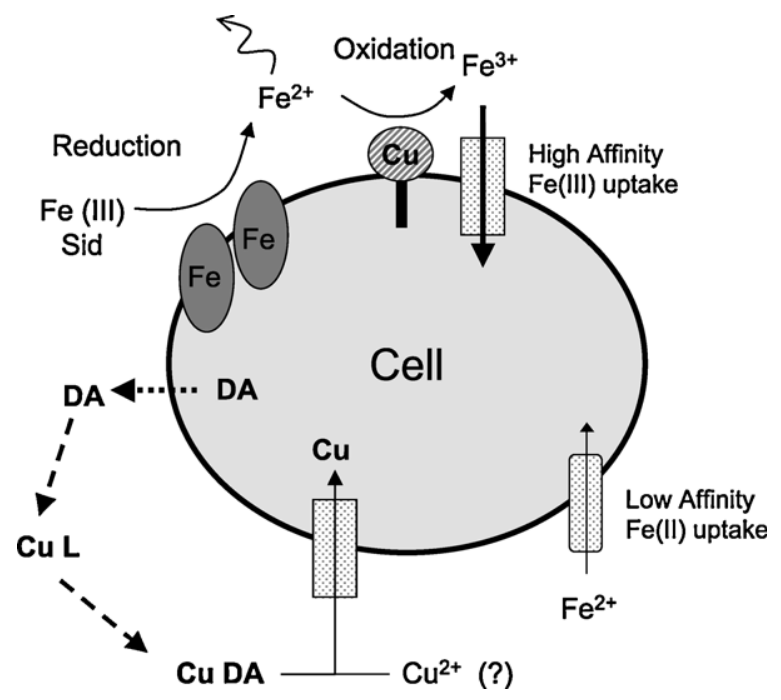

Fig. 4. Conceptual model of the high affinity iron uptake system found in yeast, $S$. cerevisiae, comprising a membrane bound, iron-containing iron reductase, a multicopper iron oxidase and high affinity $\mathrm{Fe}(\mathrm{III})$ transporter. In this sequence, organically bound $\mathrm{Fe}(\mathrm{III})$ is reduced, releasing $\mathrm{Fe}(\mathrm{II})$ from the complex. This $\mathrm{Fe}(\mathrm{II})$ may have a lifetime of minutes to hours depending on temperature, so before diffusion transports $\mathrm{Fe}(\mathrm{II})$ away for the cell it is oxidized enzymatically with the resulting $\mathrm{Fe}(\mathrm{III})$ being bound and transported into the cell. Copper uptake in this case is shown modulated by the release of DA.

From Wells et al. (2005; Fig. 8 on p. 1915).

times exceeded $1.3 \times 10^{7}$ cells $\mathrm{l}^{-1}$, and pDA reached $80 \mathrm{nmol}^{-1}$, there was no single unifying relationship between environmental conditions and either the presence of Pseudo-nitzschia or the level of DA. A similar conclusion was reached earlier by Marchetti et al. (2004). However, within one well-studied P. cuspidata bloom (September 2004), where cell concentrations reached $6.1 \times 10^{6}$ cells $^{-1}$, with pDA, dDA and cellular DA concentrations of $43 \mathrm{nmol} \mathrm{l}^{-1}, 4 \mathrm{nmol} \mathrm{l}^{-1}$ and $63 \mathrm{pg} \mathrm{cell}^{-1}$, respectively, DA levels did not correlate with macronutrient levels. Instead, stations where dissolved Fe concentrations were limiting $\left(<0.5 \mathrm{nmol} \mathrm{l}^{-1}\right)$ had the highest Pseudo-nitzschia abundances and pDA and cellular DA values (Trainer et al., 2009b). These results provide evidence that an iron-regulated physiological model is present in natural communities. A study by Ribalet et al. (2010) verified the iron mosaic of some coastal waters and suggests a Pseudo-nitzschia "hotspot", where iron-rich coastal waters meet the low-iron oceanic waters, creating a natural iron enrichment area. Presently, levels of DA in this region have not been documented.

While the physiological model linking DA production with the iron requirements of Pseudo-nitzschia cells has been proposed (Wells et al., 2005), numerous studies indicate that other environmental factors are also critical in establishing the level of DA in Pseudo-nitzschia. Key early studies (e.g. Pan et al., 1996a,b,c; reviewed by Bates et al., 2008), with a follow-up study by Fehling et al. (2004a), document a link between DA levels per Pseudo-nitzschia cell to both phosphorus- and silicate-limitation. Under these limitations, but particularly under silicate-limitation, levels of DA per Pseudo-nitzschia cell increased at early senescence stage, with little production during exponential and earlysenescence stages of growth. Similarly, in two studies considering the relationship between $\mathrm{pH} /$ dissolved inorganic carbon and DA production, the highest levels of DA per cell were achieved at high $\mathrm{pH}$, when the cell growth rate was negatively influenced (Lundholm et al., 2004; Trimborn et al., 2008). It is, however, not revealed whether it is the reduced cell growth, or the higher external $\mathrm{pH}$ resulting in potentially higher internal (intracellular) $\mathrm{pH}$ that is responsible for the higher production of DA. The effect of 
high $\mathrm{pH}$ could be part of an explanation for why dense bloom are shown to produce high levels of DA.

The common link between these sets of studies is that DA production, per se, is not connected to the growth rate of the Pseudo-nitzschia cells, only the accumulation of DA in the cells. Under any of the limiting conditions mentioned above, the cells continue to produce DA just as the rate of division decreases. This metabolic mismatch elevates the level of DA per cell simply because the DA is not being "diluted" by partitioning the new DA into new cells. Thus, it is becoming clearer that DA levels do not correspond specifically to a set environmental condition but rather to the growth characteristics of DA-accumulating cells.

Doucette et al. (2008) examined the influence of salinity on both the growth rate and DA levels per cell in $P$. multiseries. Under conditions of poor growth (10 psu), the isolate neither grew nor produced DA. At a salinity of $20 \mathrm{psu}$, cell growth rate was maximal (at $\sim 0.9 \mathrm{~d}^{-1}$ ) but DA levels were $3-7$-fold lower than cells grown at either 30 or 40 psu. The authors reject the simple relationship between cell growth rate and DA production, concluding that the extra carbon that is needed to form osmolytes at 20 psu limits that carbon pool available to produce DA.

Ecological studies provide some corroborative evidence linking nutrient status and DA production. Macintyre et al. (2011), using environmental correlations from phytoplankton communities in the Gulf of Mexico, found a strong correlation between cellular DA levels and low silicate, high salinity, high dissolved inorganic carbon and high light flux. They concluded, consistent with laboratory experiments, that DA accumulated in the cells when conditions for macronutrient uptake and growth were out of balance with photosynthetically driven carbon uptake ("photon pressure").

\subsection{Iron-fertilization studies and $D A$}

The ecological role of DA and the role of iron have been considered concurrently in several of the mesoscale ironfertilization studies. While it is generally considered that natural oceanic Pseudo-nitzschia populations do not produce DA, or only at very low levels (in the range of $\mathrm{fg} \mathrm{DAcell}^{-1}$ or $\mathrm{pg} \mathrm{DA}^{-1}$ ) (Marchetti et al., 2004, 2006, 2008), the mesoscale iron-fertilization experiments (cf. reviews by de Baar et al., 2005; Boyd et al., 2007), starting in the 1990s, have provided some opportunist information on both Pseudo-nitzschia competition and DA production. Trick et al. (2010) summarized that many of the ironfertilization experiments, where low levels of iron are added to macronutrient-rich regions of the ocean (high-nitrate, low chlorophyll; HNLC) to assess the carbon-sequestering capacity of the ocean (de Baar et al., 2008), results in a stimulation of specific species of Pseudo-nitzschia. After fertilization of open-ocean HNLC waters with iron, its nutrient composition approaches that of coastal waters and results in a Pseudo-nitzschia bloom dynamics similar to that observed in coastal or upwelling regions. Silver et al. (2010), looking at Pseudo-nitzschia abundance, estimated that DA levels in the equatorial fertilization (IronEx II) and the Southern Ocean (SOFeX) studies reached 45 and $220 \mathrm{ng} \mathrm{DA}^{-1}$, respectively.

Trick et al. (2010) presented results from in situ measurements and shipboard culture experiments demonstrating that the sparse oceanic Pseudo-nitzschia community at the HNLC Ocean Station PAPA (OSP, $50^{\circ} \mathrm{N}, 145^{\circ} \mathrm{W}$ ) could produce on the order of $\sim 200 \mathrm{pg} \mathrm{DA}^{-1}$ and retain that capacity upon iron and copper amendment. Their findings demonstrated that toxin production occurs with iron fertilization of HNLC waters, that the specific composition of commercial iron substrates is a critical parameter in the degree of toxin production, and that increasing the copper availability further enhances the cellular DA level (from 0.1 to 0.3 fg DA cell ${ }^{-1}$ ).
The experiments and oceanic observations presented in Silver et al. (2010) and Trick et al. (2010) strongly support the link between the physiological model for iron acquisition, the selective importance of DA and the recognition that total DA production potentially could reach ecologically harmful levels during largescale iron-fertilization programs.

\section{Monitoring and public health}

In most coastal regions of the world, closures of shellfish harvesting based on monitoring for DA are reactionary. Shellfish are routinely tested for toxins and harvest closures are instated only when the regulatory threshold is exceeded. This system has succeeded in protecting human health, but has often led to conservative, coastwide closures of shellfish harvesting areas, which negatively impacts the shellfish industry and the economy. Sentinel shellfish, typically mussels in cages, may not always provide the best warning of DA events. Alternatives to mussels, including crustaceans that retain toxins (Powell et al., 2002), or solid phase adsorption toxin tracking (SPATT) technology (Lane et al., 2010) can provide a more effective "history" of DA in the phytoplankton assemblage or in shellfish.

A combination of more proactive approaches to monitoring that allow targeted closures have been demonstrated. In the case of eastern oysters (Crassostrea virginica) from Atlantic Canada, it has been demonstrated that blanket closures that prohibit the harvesting of all shellfish species may not be necessary, because these oysters accumulate little, or no, DA at the same location where other shellfish species are over the regulatory limit (Mafra et al., 2009a,b, 2010b). In another example, from the coast of Washington State, the Olympic Region Harmful Algal Bloom (ORHAB) monitoring partnership uses a simple combination of analytical techniques, which includes weekly determination of total Pseudo-nitzschia cells using light microscopy and levels of particulate DA in seawater, using antibody-based methods (B.-T. L. Eberhart, pers. comm.), to give an effective early warning of shellfish toxification events.

In order to sustain a monitoring program such as ORHAB, progressive integration of newer methods into the state management plans for HABs must occur. By rapidly assisting managers during toxic bloom events, ORHAB partners have effectively demonstrated to state legislators how integral the monitoring program is to effective and timely management of shellfish resources. Resulting legislation has instated a surcharge on shellfish license fees that will provide enough funding to sustain a state-run program, when the federally funded program ended in 2005.

Beach monitoring programs such as ORHAB are now being integrated with fine-scale sampling, using automated devices on moorings, to allow detailed determination of fluctuations in biological, physical and chemical parameters that influence $\mathrm{HAB}$ intensity. An example of a remote sensing technology is the automated molecular detection and quantification of Pseudonitzschia cells and DA, using the environmental sample processor (ESP; Scholin et al., 1999; Greenfield et al., 2006, 2008; Doucette et al., 2009).

Developing forecasting capability for the transport and impact of toxic Pseudo-nitzschia blooms will require sustained monitoring as well as additional efforts in the critical areas of basic research and model development. This early warning network for the detection and transport of toxic Pseudo-nitzschia blooms will ultimately use an integrated suite of sensors on satellites and stationary sensor platforms that measure ocean water properties, currents, Pseudo-nitzschia cell numbers and DA; using telemetry, these data will add real-time elements to shore-based lab testing. The suite of real-time data from moorings will also be used to 
initialize, calibrate and validate physical and biological models and associated forecasts. Such models will allow monitoring programs and health departments to take preventive actions (e.g. increase monitoring efforts, close targeted shellfish beds, warn at-risk communities) to safeguard public health, local economies and fisheries. In addition, an integrated forecasting system will allow the proactive management of resources, e.g. by making possible the early opening of the recreational and subsistence clamming seasons or early warning to commercial crab and clam fishers who are impacted by DA-related closures. Together, these technologies will result in the most accurate forecasting bulletins possible, for the early warning of $\mathrm{HAB}$ events. One such bulletin for the Washington State coast is currently in its pilot stage (see http:// pnwhabs.org/pnwhabbulletin/index.html).

\section{Future needs}

In the over two decades since the first deaths associated with the DA outbreak in Prince Edward Island, Canada, considerable progress has been achieved in all areas of the science of Pseudonitzschia. The rapid initial characterization of the toxin, and the clear establishment of the causative genus, have opened the door to extensive, hypothesis-driven research on factors that lead to toxic bloom development and ways to avoid future incidence of ASP. Researchers have challenged our scientific understanding at all levels - from the global ecology to the genome similarities among DA-producing strains. With all the progress achieved so far, the unique nature of Pseudo-nitzschia offers considerable potential for continued, intensive study. Uncertainty still abounds, however, and opportunity exists at all levels of research.

The complex nature of Pseudo-nitzschia taxonomy, based on physical size, shape and frustule ornamentation, phylogenetics and the breakthroughs made on elucidating the sexual reproduction of this diatom, provide a foundation for future studies on functional genome analysis, evolutionary genetic associations and molecular probe development. The advancement of the complex taxonomy is critical to the development of ecophysiological and toxicological studies.

The geographical mosaic of Pseudo-nitzschia presence and distribution has been considered in detail at some specific locations - primarily regions of upwelling - and coastal-open ocean interfaces. However, we now recognize the broader potential of toxigenic Pseudo-nitzschia, even in open-ocean environments and in non-traditional ocean zones susceptible to the influences of human activities. Are these areas where Pseudonitzschia can outcompete other species or are these transition zones where Pseudo-nitzschia thrives due to the lower competitive ability of other species to the dynamically changing environmental conditions? To achieve this understanding, more routine monitoring that allows characterization of the initiation and development of blooms, with the careful notation of conditions that correlate to a bloom or its toxicity, is essential. Accumulated knowledge often describes conditions present during a bloom, implying that these factors may also be instrumental in promoting the bloom. This is not necessarily the case, as it is likely that Pseudo-nitzschia may modify or condition the waters, allowing it establish an ecological advantage for growth. Challenging, persistent work is required, using a combination of modern molecular tools, to determine population structure. Careful microscopic observation of both live and preserved material is nevertheless essential to witness unique morphologies, including sexual stages (Fig. 2) and declining cell sizes.

The conditioning of seawater by established, growing populations of Pseudo-nitzschia has not received adequate attention, even with our increasing appreciation that DA or other metabolites could be involved in allelopathic, anti-grazing or sexual reproduction activities. These processes may be fundamental in establishing the ecological complexity of Pseudo-nitzschia abundance or bloom establishment.

A better understanding of the currently uncertain role of DA production is fundamental to our understanding of the ecology of toxic and nontoxic species of Pseudo-nitzschia. While recognized as a compound transferred though the food web, resulting in mammal, bird and human health damage, alternative roles for DA may assist Pseudo-nitzschia in establishing itself in a unique or modified ecological space. Its documented chelation of iron and copper may enhance species-specific iron acquisition or may reduce free copper or exchange copper from established weakcopper ligands, e.g. produced by cyanobacteria. If DA does play a role in the acquisition of trace metals by Pseudo-nitzschia, then why are new DA closure events occurring in nearshore waters where trace metals should be in abundance? The answer may lie in the study of the bioavailability of these trace metals and their complexation by organic material in the coastal ocean. Alternatively, the ecological competitiveness of Pseudo-nitzschia may be enhanced if DA functions as dynamic anti-grazing infochemical - a biologically active metabolite, stored intracellularly then released extracellularly, when grazing levels increase. Uncertainties remain regarding DA production, storage and release, but this opens new options for studying its potential role as a cell "communication" molecule that could help to explain the ecological success of toxigenic Pseudo-nitzschia species. Interactions between bacteria (epibiotic and extracellular) and Pseudo-nitzschia, in relation to DA production (reviewed by Bates, 1998; Kaczmarska et al., 2005; Guannel et al., 2011) may also provide an advantage to this diatom. In contrast to the success of DA-producing species, one must also ask what comparable strategies may be used by those Pseudonitzschia species that do not produce this toxin, yet are still successful.

Does the key to understanding the nature of Pseudo-nitzschia harmfulness lie in an understanding of its versatility relative to other phytoplankton? Pseudo-nitzschia blooms occur in the most pristine (Juan de Fuca eddy region; Trainer et al., 2009a) waters, as well as in some of the most nutrient-impacted (Gulf of Mexico; Parsons et al., 2002), nutrient-variable (Monterey Bay, CA), or nutrient-poor oceanic (Trick et al., 2010; Silver et al., 2010) waters. Is Pseudo-nitzschia more versatile at adapting to variable environmental regimes, e.g. by effective use of macronutrients, scavenging potentially limiting trace elements, or by maintaining sustenance nutrients during bloom senescence, when its competitors are not? Evidence points to this possibility. Pseudo-nitzschia thrives under a variety of macronutrient conditions by effectively using nitrate, ammonium and urea as a sole nitrogen source. The link between nitrogen source and toxin production, where maximum toxin production is expressed by cells grown on the more complex source (urea) (Radan, 2008), illustrates the need to better understand the relationship between primary cell metabolism and secondary metabolism.

Confining regular sampling to the bloom formation phase, without a serious consideration of either bloom maintenance or demise, may restrict our ability to describe the overall ecology and significance of Pseudo-nitzschia. Careful microscopic observation of Pseudo-nitzschia cells during prolonged events will help determine the possible importance of parasites (Fig. 3) and/or viruses in bloom decline, and the significance of the momentary halt in vegetative cell proliferation while the cells undergo sexual reproduction. This, plus the use of molecular probes, may help to determine if toxigenicity may help protect the cells from microbial, fungal or viral attack. Perhaps the long, sustained bloom conditions provide both ecological and evolutionary histories, aiding in the redistribution of seed populations. Biochemical and molecular tools should continue to be developed to allow us to 
monitor cell health and signaling pathways that may regulate toxicity.

The negative impacts of this species on human, marine mammal and bird health, highlight the intense social need for timely and critical Pseudo-nitzschia research. The complexity of the taxonomy, toxin production, toxin storage/release, bloom initiation/retention, and nutrient requirements places Pseudo-nitzschia as an ideal genus for intense scientific inquiry. Our accumulated knowledge of this genus opens further research opportunities, provides a means to critically evaluate the macro- and microphysiology of phytoplankton, and offers a model system to assess the importance of an established toxin in ecotoxicological studies and as a possible info-chemical for affecting cellular, population and community dynamics.

\section{Acknowledgments}

We thank the following researchers for information on toxic Pseudo-nitzschia blooms and/or DA in their respective countries: Tatiana Orlova and Inna Stonik (Russia), R. Liu (China), Ernesto García-Mendoza and, Yuri Okolodkov (Mexico), Caroline Cusack and Joe Silke (Ireland), Eileen Bresnan (Scotland), Yolanda Pazos (Spain), Luiz Mafra (Brazil), Leonardo Guzmán (Chile), Gustaaf Hallegraeff (Australia), Gregory Doucette (Namibia), Paulo Vale (Portugal).

\section{References}

Adams, N.G., Lesoing, M., Trainer, V.L., 2000. Environmental conditions associated with domoic acid in razor clams on the Washington coast. J. Shellfish Res. 19, 1007-1015.

Adams, N.G., Trainer, V.L., Rocap, G., Herwig R.P., Hauser, L., 2009. Genetic popula tion structure of Pseudo-nitzschia pungens (Bacillariophyceae) from the Pacific Northwest and the North Sea. J. Phycol. 45, 1037-1045.

Almandoz, G.O., Ferrario, M.E., Ferreyra, G.A., Schloss, I.R., Esteves, J.L., Paparazzo, F.E., 2007. The genus Pseudo-nitzschia (Bacillariophyceae) in continental shelf waters of Argentina (Southwestern Atlantic Ocean, 38-55 ${ }^{\circ}$ ). Harmful Algae 6, 93-103.

Almandoz, G.O., Hernando, M., Ferrario, M.E., 2009. SEM observations of Pseudonitzschia from Beagle channel: P. seriata in the southern hemisphere? Harmful Algae News 39, 6-7.

Altwein, D.M., Foster, K., Doose, G., Newton, R.T., 1995. The detection and distribution of the marine neurotoxin domoic acid on the Pacific Coast of the United States 1991-1993. J. Shellfish Res. 14, 217-222.

Álvarez, G., Uribe, E., Quijano-Scheggia, S., López-Rivera, A., Mariño, C., Blanco, J., 2009. Domoic acid production by Pseudo-nitzschia australis and Pseudo-nitzschia calliantha isolated from North Chile. Harmful Algae 8, 938-945.

Álvarez, R.Z., 1968. Iberian decapod crustaceans. Investigación Pesquera 32, 1-510.

Amato, A., Orsini, L., D’Alelio, D., Montresor, M., 2005. Life cycle, size reduction patterns, and ultrastructure of the pennate planktonic diatom Pseudo-nitzschia delicatissima (Bacillariophyceae). J. Phycol. 41, 542-556.

Amato, A., Kooistra, W.H.C.F., Ghiron, J.H.L., Mann, D.G., Proschold, T., Montresor, M. 2007. Reproductive isolation among sympatric cryptic species in marine diatoms. Protist 158, 193-207.

Amato, A., Montresor, M., 2008. Morphology, phylogeny, and sexual cycle of Pseudonitzschia mannii sp. nov. (Bacillariophyceae): a pseudo-cryptic species within the $P$. pseudodelicatissima complex. Phycologia 47, 487-497.

Amato, A., Lüdeking, A., Kooistra, W.H.C.F., 2010. Intracellular domoic acid production in Pseudo-nitzschia multistriata isolated from the Gulf of Naples (Tyrrhenian Sea Italy). Toxicon 55, 157-161.

Amorim, A., Moniz, M., Rodrigues, S.M., Veloso, V., Frazão, B., Matos, A.P.A., Ehrman, J., Kaczmarska, I., 12-15 May 2009. Espécies de Pseudo-nitzschia da baía de Lisboa. In: X Reunião Ibérica de Fitoplâncton Tóxico e Biotoxinas LISBOA. Instituto Nacional dos Recursos Biológicos IP, IPIMAR, (Abstract), p. 14

Amzil, Z., Fresnel, J., Le Gal, D., Billard, C., 2001. Domoic acid accumulation in French shellfish in relation to toxic species of Pseudo-nitzschia multiseries and $P$. pseudodelicatissima. Toxicon 39, 1245-1251.

Anderson, C.R., Brzezinski, M.A., Washburn, L., Kudela, R., 2006. Circulation and environmental conditions during a toxigenic Pseudo-nitzschia australis bloom in the Santa Barbara Channel, California. Mar. Ecol. Prog. Ser. 327, 119-133.

Anderson, C.R., Siegel, D.A., Brzezinski, M.A., Guillocheau, N., 2008. Controls on temporal patterns in phytoplankton community structure in the Santa Barbara Channel, California. J. Geophys. Res. 113, C04038, doi:10.1029/2007jc004321.

Arévalo, F. Bermúdez de la Puente, M., Salgado, C., 1998. ASP toxicity in scallops: individual variability and tissue distribution. In: Reguera, B., Blanco, J., Fernández, M.L., Wyatt, T. (Eds.), Harmful Algae. Xunta de Galicia and the IOC of UNESCO, Paris, pp. 499-502.
Arzul, G., Erard-LeDenn, E., Videau, C., Jegou, A.M., Gentien, P., 1993. Diatom growth repressing factors during an offshore bloom of Gyrodinium cf. aureolum. In: Smayda, T.J., Shimizu, Y. (Eds.), Toxic Phytoplankton Blooms in the Sea. Elsevier Sci. Publ. BV, Amsterdam, pp. 719-724.

Auro, M.E., 2007. Nitrogen dynamics and toxicity of the pennate diatom Pseudonitzschia cuspidata: a field and laboratory study. Masters Thesis. San Francisco State University, San Francisco, CA. 91 pp.

Bargu, S., Powell, C.L., Coale, S.L., Busman, M., Doucette, G.J., Silver, M.W., 2002. Krill: a potential vector for domoic acid in marine food webs. Mar. Ecol. Prog. Ser. 237, 209-216.

Bargu, S., Silver, M.W., 2003. Field evidence of krill grazing on the toxic diatom genus Pseudo-nitzschia in Monterey Bay, California. Bull. Mar. Sci. 72, 629-638.

Bargu, S., Powell, C.L., Wang, Z.H., Doucette, G.J., Silver, M.W., 2008. Note on the occurrence of Pseudo-nitzschia australis and domoic acid in squid from Monterey Bay, CA (USA). Harmful Algae 7, 45-51.

Bargu, S., Silver, M., Goldstein, T., Roberts, K., Gulland, F., 2010. Complexity of domoic acid-related sea lion strandings in Monterey Bay, California: foraging patterns, climate events, and toxic blooms. Mar. Ecol. Prog. Ser. 418, 213-222.

Bargu, S., Goldstein, T., Roberts, K., Li, C., Gulland, F., Pseudo-nitzschia blooms, domoic acid, and related California sea lion strandings in Monterey Bay, California. Mar. Mamm. Sci. published online, in press.

Bates, S.S., Bird, C.J., de Freitas, A.S.W., Foxall, R., Gilgan, M., Hanic, L.A., Johnson, G.R., McCulloch, A.W., Odense, P., Pocklington, R., Quilliam, M.A., Sim, P.G., Smith, J.C., Subba Rao, D.V., Todd, E.C.D., Walter, J.A., Wright, J.L.C., 1989. Pennate diatom Nitzschia pungens as the primary source of domoic acid, a toxin in shellfish from eastern Prince Edward Island, Canada. Can. J. Fish. Aquat. Sci. 46, 12031215.

Bates, S.S., de Freitas, A.S.W., Milley, J.E., Pocklington, R., Quilliam, M.A., Smith, J.C., Worms, J., 1991. Controls on domoic acid production by the diatom Nitzschia pungens f. multiseries in culture: nutrients and irradiance. Can. J. Fish. Aquat. Sci. $48,1136-1144$

Bates, S.S., Worms, J., Smith, J.C., 1993. Effects of ammonium and nitrate on growth and domoic acid production by Nitzschia pungens in batch culture. Can. J. Fish. Aquat. Sci. 50, 1248-1254.

Bates, S.S., Léger, C., Smith, K.M., 1996. Domoic acid production by the diatom Pseudo-nitzschia multiseries as a function of division rate in silicate-limited chemostat culture. In: Yasumoto, T., Oshima, Y., Fukuyo, Y. (Eds.), Harmful and Toxic Algal Blooms. Seventh International Conference on Toxic Phytoplankton, UNESCO. Sendai, Japan, pp. 163-166.

Bates, S.S., 1998. Ecophysiology and metabolism of ASP toxin production. In: Anderson, D.M., Cembella, A.D., Hallegraeff, G.M. (Eds.), Physiological Ecology of Harmful Algal Blooms. Springer-Verlag, Berlin, pp. 405-426.

Bates, S.S., Garrison, D.L., Horner, R.A., 1998. Bloom dynamics and physiology of domoic-acid-producing Pseudo-nitzschia species. In: Anderson, D.M., Cembella, A.D., Hallegraef, G.M. (Eds.), Physiological Ecology of Harmful Algal Blooms. Springer-Verlag, Berlin, pp. 267-292.

Bates, S.S., Hiltz, M.F., Léger, C., 1999. Domoic acid toxicity of large new cells of Pseudo-nitzschia multiseries resulting from sexual reproduction. In: Martin, J.L., Haya, K. (Eds.), Proceedings of the Sixth Canadian Workshop on Harmful Marine Algae, Can. Tech. Rep. Fish. Aquat. Sci. 2261, pp. 21-26.

Bates, S.S., Léger, C., Satchwell, M.F., Boyer, G.L., 2001. The effects of iron on domoic acid production by Pseudo-nitzschia multiseries. In: Hallegraeff, G.M., Blackburn, S.I., Bolch, C.J., Lewis, R.J. (Eds.), Harmful Algal Blooms 2000. Intergovernmental Oceanographic Commission of UNESCO, Paris, pp. 320-323.

Bates, S.S., Davidovich, N.A., 2002. Factors affecting the sexual reproduction of diatoms, with emphasis on Pseudo-nitzschia spp. In: Garcés, E., Zingone, A., Dale, B., Montresor, M., Reguera, B. (Eds.), Proceedings of the LIFEHAB Workshop: Life history of microalgal species causing harmful algal blooms. European Commission Report No. EUR 20361, pp. 31-36.

Bates, S.S., Léger, C., White, J.M., MacNair, N., Ehrman, J.M., Levasseur, M., Couture, J.Y., Gagnon, R., Bonneau, E., Michaud, S., Sauvé, G., Chassé, J., 2002. Domoic acid production by the diatom Pseudo-nitzschia seriata causes spring closures of shellfish harvesting for the first time in the Gulf of St. Lawrence, eastern Canada. In: 10th International Conference on Harmful Algae. St. Pete Beach, Florida, October 21-25, 2002, (Abstract), p. 23.

Bates, S.S., 2004. Amnesic shellfish poisoning: domoic acid production by Pseudonitzschia diatoms. Aqua Info Aquacu. Notes 16, 4., In: http://www.gov.pe.ca/ photos/original/af_domoic_acid.pdf.

Bates, S.S., Trainer, V.L., 2006. The ecology of harmful diatoms. In: Granéli, E.,Turner J.T. (Eds.), Ecology of Harmful Algae. Springer-Verlag, Berlin, pp. 81-88.

Baugh, K.A., Bush, J.M., Bill, B.D., Lefebvre, K.A., Trainer, V.L., 2006. Estimates of specific toxicity in several Pseudo-nitzschia species from the Washington coast, based on culture and field studies. Afr. J. Mar. Sci. 28, 403-407.

Bejarano, A.C., Van Dola, F.M., Gulland, F.M., Rowles, T.K., Schwacke, L.H., 2008. Production and toxicity of the marine biotoxin domoic acid and its effects on wildlife: a review. Hum. Ecol. Risk Assess. 14, 544-567.

Besiktepe, S., Ryabushko, L., Ediger, D., Yimaz, D., Zenginer, A., Ryabushko, V., Lee, R., 2008. Domoic acid production by Pseudo-nitzschia calliantha Lundholm, Moestrup et Hasle (Bacillariophyta) isolated from the Black Sea. Harmful Algae 7, 438-442.

Bill, B.D., Cox, F.H., Horner, R.A., Borchert, J.A., Trainer, V.L., 2006. The first closure of shellfish harvesting due to domoic acid in Puget Sound, Washington, USA. Afr. J. Mar. Sci. 28, 435-440.

Bill, B.D., 2011. Carbon and nitrogen uptake of toxigenic diatoms: Pseudo-nitzschia australis and Pseudo-nitzschia turgidula. Masters Thesis. San Francisco State University, San Francisco, CA, 118 pp. 
Blanco, J., Acosta, C.P., Bermúdez de la Puente, M., Salgado, C., 2002. Depuration and anatomical distribution of the amnesic shellfish poisoning (ASP) toxin domoic acid in the king scallop Pecten maximus. Aquat. Toxicol. 60, 111-121.

Bogan, Y.M., Kennedy, D., Harkin, A.L., Gillespie, J., Hess, P., Slater, J.W., 2006 Comparison of domoic acid concentration in king scallops, Pecten maximus from seabed and suspended culture systems. J. Shellfish Res. 25, 129-135.

Bogan, Y.M., Bender, K., Hervas, A., Kennedy, D.J., Slater, J.W., Hess, P., 2007a. Spatial variability of domoic acid concentration in king scallops Pecten maximus off the southeast coast of Ireland. Harmful Algae 6, 1-14.

Bogan, Y.M., Harkin, A.L., Gillespie, J., Kennedy, D.J., Hess, P., Slater, J.W., 2007b. The influence of size on domoic acid concentration in king scallop, Pecten maximus (L.). Harmful Algae 6, 15-28.

Boyd, P.W., Jickells, T., Law, C.S., Blain, S., Boyle, E.A., Buesseler, K.O., Coale, K.H., Cullen, J.J., de Baar, H.J.W., Follows, M., Harvey, M., Lancelot, C., Levasseur, M., Owens, N.P.J., Pollard, R., Rivkin, R.B., Sarmiento, J., Schoemann, V., Smetacek, V., Takeda, S., Tsuda, A., Turner, S., Watson, A.J., 2007. Mesoscale iron enrichment experiments 1993-2005: synthesis and future directions. Science 315, 612617.

Bresnan, E., 2003. Monitoring programme for toxic phytoplankton in Scottish coastal waters. 1 April 2002-31 March 2003, Fisheries Research Services Contract Report 14/03, 53 pp. Available at http://www.scotland.gov.uk/ Uploads/Documents/1403.pdf.

Buck, K.R., Uttalcooke, L., Pilskaln, C.H., Roelke, D.L., Villac, M.C., Fryxell, G.A Cifuentes, L., Chavez, F.P., 1992. Autecology of the diatom Pseudo-nitzschia australis, a domoic acid producer, from Monterey Bay, California. Mar. Ecol. Prog. Ser. 84, 293-302.

Buck, K.R., Marin III, R., Chavez, F.P., 2005. Heterotrophic dinoflagellate fecal pellet production: grazing of large, chain-forming diatoms during upwelling events in Monterey Bay, California. Aquat. Microb. Ecol. 40, 293-298.

Burns, J.M., Ferry, J.L., 2007. Adsorption of domoic acid to marine sediments and clays. J. Environ. Monit. 9, 1373-1377.

Bursa, A., 1963. Phytoplankton in coastal waters of the Arctic Ocean at Point Barrow, Alaska. Arctic 16, 239-262.

Busse, L.B., Venrick, E.L., Antrobus, R., Miller, P.E., Vigilant, V., Silver, M.W., Mengelt C., Mydlarz, L., Prezélin, B.B., 2006. Domoic acid in phytoplankton and fish in San Diego, CA, USA. Harmful Algae 5, 91-101.

Calu, G., Martin-Jezequel, V., Lefau, E., Sechet, V., Lassus, P., Weigel, P., Amzil, Z. 2009. The influence of nitrogen speciation on growth and toxicity of Pseudonitzschia multiseries and $P$. pungens in batch and continuous cultures. In: Lassus, P. (Ed.), 7th International Conference on Molluscan Shellfish Safety. Nantes, France, p. 7.

Campbell, D.A., Kelly, M.S., Busman, M., Bolch, C.J., Wiggins, E., Moeller, P.D.R., Morton, S.L., Hess, P., Shumway, S.E., 2001. Amnesic shellfish poisoning in the king scallop, Pecten maximus, from the west coast of Scotland. J. Shellfish Res. 20, 75-84.

Campbell, D.A., Kelly, M.S., Busman, M., Wiggins, E., Fernandes, T.F., 2003. Impact of preparation method on gonad domoic acid levels in the scallop, Pecten maximus (L.). Harmful Algae 2, 215-222.

Carlson, M., Johnson, B., Rocap, G., 2009. Viral-phytoplankton interactions: characterization and ecology of viruses infecting the diatom Pseudo-nitzschia. In: 5th Symposium on Harmful Algae in the U.S. Ocean Shores, WA, (Abstract), p. 101.

Casteleyn, G., Chepurnov, V.A., Leliaert, F., Mann, D.G., Bates, S.S., Lundholm, N., Rhodes, L., Sabbe, K., Vyverman, W., 2008. Pseudo-nitzschia pungens (Bacillariophyceae): a cosmopolitan diatom species? Harmful Algae 7, 241-257.

Casteleyn, G., Adams, N.G., Vanormelingen, P., Debeer, A.E., Sabbe, K., Vyverman, W. 2009a. Natural hybrids in the marine diatom Pseudo-nitzschia pungens (Bacillariophyceae): genetic and morphological evidence. Protist 160, 343-354.

Casteleyn, G., Evans, K.M., Backeljau, T., D'Hondt, S., Chepurnov, V., Sabbe, K., Vyverman, W., 2009b. Lack of population genetic structuring in the marine planktonic diatom Pseudo-nitzschia pungens (Bacillariophyceae) in a heterogeneous area in the Southern Bight of the North Sea. Mar. Biol. 156, 1149-1158.

Casteleyn, G., Leliaert, F., Backeljau, T., Debeer, A.E., Kotaki, Y., Rhodes, L., Lundholm, N., Sabbe, K., Vyverman, W., 2010. Limits to gene flow in a cosmopolitan marine planktonic diatom. Proc. Natl. Acad. Sci. U.S.A. 107, 12952-12957.

Cendes, F., Andermann, F., Carpenter, S., Zatorre, R.J., Cashman, N.R., 1995. Temporal lobe epilepsy caused by domoic acid intoxication: evidence for glutamate receptor-mediated excitotoxicity in humans. Ann. Neurol. 37, 123-126.

Cerino, F., Orsini, L., Sarno, D., Dell'Aversano, C., Tartaglione, L., Zingone, A., 2005. The alternation of different morphotypes in the seasonal cycle of the toxic diatom Pseudo-nitzschia galaxiae. Harmful Algae 4, 33-48.

Chepurnov, V.A., Mann, D.G., Sabbe, K., Vyverman, W., 2004. Experimental studies on sexual reproduction in diatoms. Int. Rev. Cytol. Sur. Cell Biol. 237, 91-154.

Chepurnov, V.A., Mann, D.G., Sabbe, K., Vannerum, K., Casteleyn, G., Verleyen, E. Peperzak, L., Vyverman, W., 2005. Sexual reproduction, mating system, chloroplast dynamics and abrupt cell size reduction in Pseudo-nitzschia pungens from the North Sea (Bacillariophyta). Eur. J. Phycol. 40, 379-395.

Cho, E.S., Kotaki, Y., Park, J.G., 2001. The comparison between toxic Pseudo-nitzschia multiseries (Hasle) Hasle and non-toxic $P$. pungens (Grunow) Hasle isolated from Jinhae Bay, Korea. Algae 16, 275-285.

Churro, C.I., Carreira, C.C., Rodrigues, F.J., Craveiro, S.C., Calado, A.J., Casteleyn, G., Lundholm, N., 2009. Diversity and abundance of potentially toxic PseudoNitzschia Peragallo in Aveiro Coastal Lagoon, Portugal and description of a new variety. P-pungens var. aveirensis Var. nov. Diatom Res. 24, 35-62.

Cochlan, W.P., Herndon, J., Ladizinsky, N.C., Kudela, R.M., 2006a. Nitrogen uptake by the toxigenic diatom Pseudo-nitzschia australis. EOS Trans. Am. Geophys. Union 87 (suppl. (36))
Cochlan, W.P., Wells, M.L., Trainer, V.L., Trick, C.G., Lessard, E.J., Hickey, B., 2006b. Domoic acid production is not linked to silicate limitation in natural populations of Pseudo-nitzschia. In: Twelfth International Conference on Harmful Algae. Copenhagen, DK, September 2006 (Abstract).

Cochlan, W.P., Herndon, J., Kudela, R.M., 2008. Inorganic and organic nitrogen uptake by the toxigenic diatom Pseudo-nitzschia australis (Bacillariophyceae). Harmful Algae 8, 111-118

Coleman, A.W., 2000. The significance of a coincidence between evolutionary landmarks found in mating affinity and a DNA sequence. Protist 151, 1-9.

Coleman, A.W., 2003. ITS2 is a double-edged tool for eukaryote evolutionary comparisons. Trends Genet. 19, 370-375.

Coleman, A.W., 2007. Pan-eukaryote ITS2 homologies revealed by RNA secondary structure. Nucleic Acids Res. 35, 3322-3329.

Coleman, A.W., 2009. Is there a molecular key to the level of "biological species" in eukaryotes? A DNA guide. Mol. Phylogen. Evol. 50, 197-203.

Costa, P.R., Rodrigues, S.M., Botelho, M.J., Sampayo, M.A.U., 2003. A potential vector of domoic acid: the swimming crab Polybius henslowii Leach (Decapoda-Brachyura). Toxicon 42, 135-141.

Costa, P.R., Garrido, S., 2004. Domoic acid accumulation in the sardine Sardina pilchardus and its relationship to Pseudo-nitzschia diatom ingestion. Mar. Ecol. Prog. Ser. 284, 261-268.

Costa, P.R., Rosa, R., Sampayo, M.A.M., 2004. Tissue distribution of the amnesic shellfish toxin, domoic acid, in Octopus vulgaris from the Portuguese coast. Mar. Biol. 144, 971-976

Costa, P.R., Rosab, R., Duarte-Silva, A., Brotas, V., Sampayo, M.A.M., 2005. Accumulation, transformation and tissue distribution of domoic acid, the amnesic shellfish poisoning toxin, in the common cuttlefish, Sepia officinalis. Aquat. Toxicol. 74, 82-91.

Couture, J.Y., Levasseur, M., Bonneau, E., Desjardins, C., Sauve, G., Bates, S.S., Léger, C., Gagnon, J., Michaud, S., 2001. Spatial and temporal variation of domoic acid in molluscs and of Pseudo-nitzschia spp. blooms in the St. Lawrence from 1998 to 2000. Can. Tech. Rep. Fish. Aquat. Sci. 2375, vii +24 p.

Cupp, E.E., 1943. Marine Plankton Diatoms of the West Coast of North America, Technical Series Bulletin. Scripps Institution of Oceanography, $238 \mathrm{pp}$.

Cusack, C.K., Bates, S.S., Quilliam, M.A., Patching, J.W., Raine, R., 2002. Confirmation of domoic acid production by Pseudo-nitzschia australis (Bacillariophyceae) isolated from Irish waters. J. Phycol. 38, 1106-1112.

D'Alelio, D., Amato, A., Luedeking, A., Montresor, M., 2009. Sexual and vegetative phases in the planktonic diatom Pseudo-nitzschia multistriata. Harmful Algae 8 225-232.

Dao, H.V., Takata, Y., Omura, T., Sato, S., Fukuyo, Y., Kodama, M., 2009. Seasonal variation of domoic acid in a bivalve Spondylus versicolor in association with that in plankton samples in Nha Phu Bay, Khanh Hoa, Vietnam. Fish. Sci. 75, 507512.

Davidovich, N.A., Bates, S.S., 1998. Sexual reproduction in the pennate diatoms Pseudo-nitzschia multiseries and P. pseudodelicatissima (Bacillariophyceae). J. Phycol. 34, 126-137.

de Baar, H.J.W., Boyd, P.W., Coale, K.H., Landry, M.R., Tsuda, A., Assmy, P., Bakker, D.C.E., Bozec, Y., Barber, R.T., Brzezinski, M.A., Buesseler, K.O., Boyé, M., Croot P.L., Gervais, F., Gorbunov, M.Y., Harrison, P.J., Hiscock, W.T., Laan, P., Lancelot, C., Law, C.S., Levasseur, M., Marchetti, A., Millero, F.J., Nishioka, J., Nojiri, Y., van Oijen, T., Riebesell, U., Rijkenberg, M.J.A., Saito, H., Takeda, S., Timmermans, K.R. Veldhuis, M.J.W., Waite, A.M., Wong, C.-S., 2005. Synthesis of iron fertilization experiments: from the iron age in the age of enlightenment. J. Geophys. Res. 110, C09S16, doi:10.1029/2004JC002601.

de Baar, H.J.W., Gerringa, L.J.A., Laan, P., Timmermans, K.R., 2008. Efficiency of carbon removal per added iron in ocean iron fertilization. Mar. Ecol. Prog. Ser 364, 269-282.

Del Rio, R., Bargu, S., Baltz, D., Fire, S., Peterson, G., Wang, Z.H., 2010. Gulf menhaden (Brevoortia patronus): a potential vector of domoic acid in coastal Louisiana food webs. Harmful Algae 10, 19-29.

Department of Fisheries and Oceans, 1992. 1992 summary of marine toxin records in the Pacific Region. Department of Fisheries and Oceans, Inspection and Special Services Branch, Burnaby, British Columbia. Unpaginated.

Dortch, Q., 1990. The interaction between ammonium and nitrate uptake in phytoplankton. Mar. Ecol. Prog. Ser. 61, 183-201.

Dortch, Q., Robichaux, R., Pool, S., Milsted, D., Mire, G., Rabalais, N.N., Soniat, T.M. Fryxell, G.A., Turner, R.E., Parsons, M.L., 1997. Abundance and vertical flux of Pseudo-nitzschia in the northern Gulf of Mexico. Mar. Ecol. Prog. Ser. 146, 249264.

Doucette, G.J., King, K.L., Thessen, A.E., Dortch, Q., 2008. The effect of salinity on domoic acid production by the diatom Pseudo-nitzschia multiseries. Nova Hedwigia, Beiheft 133, 31-46.

Doucette, G.J., Mikulski, C.M., Jones, K.L., King, K.L., Greenfield, D.I., Marin III, R., Jensen, S., Roman, B., Elliott, C.T., Scholin, C.A., 2009. Remote, subsurface detection of the algal toxin domoic acid onboard the Environmental Sample Processor: assay development and field trials. Harmful Algae 8, 880-888.

Douglas, D.J., Kenchington, E.R., Bird, C.J., Pocklington, R., Bradford, B., Silvert, W., 1997. Accumulation of domoic acid by the sea scallop (Placopecten magellanicus) fed cultured cells of toxic Pseudo-nitzschia multiseries. Can. J. Fish. Aquat. Sci. 54 907-913.

Dyson, K., Huppert, D.D., 2010. Regional economic impacts of razor clam beach closures due to harmful algal blooms (HABs) on the Pacific coast of Washington. Harmful Algae 9, 264-271.

EFSA, 2009. Scientific opinion of the panel on contaminants in the food chain on a request from the European Commission on marine biotoxins in shellfish- 
domoic acid. Eur. Food Safety Authority J. 1181, 1-61 Available at http:// www.efsa.europa.eu/en/efsajournal/doc/1181.pdf.

Ennaffah, B., 2007. The first records of potentially toxic species of Pseudo-nitzschia in Moroccan Atlantic waters. Harmful Algae in North Africa. Available at http:// www.ioc-unesco.org/hab/index.php?option=com_oe\&task=viewDoclistRecord\& doclistID=63 (Abstract)

Escalera, L., Pazos, Y., Morono, A., Reguera, B., 2007. Noctiluca scintillans may act as a vector of toxigenic microalgae. Harmful Algae 6, 317-320.

Evans, K.M., Bates, S.S., Medlin, L.K., Hayes, P.K., 2004. Microsatellite marke development and genetic variation in the toxic marine diatom Pseudo-nitzschia multiseries (Bacillariophyceae). J. Phycol. 40, 911-920.

Evans, K.M., Hayes, P.K., 2004. Microsatellite markers for the cosmopolitan marine diatom Pseudo-nitzschia pungens. Mol. Ecol. Notes 4, 125-126.

Evans, K.M., Kuhn, S.F., Hayes, P.K., 2005. High levels of genetic diversity and low levels of genetic differentiation in North Sea Pseudo-nitzschia pungens (Bacillariophyceae) populations. J. Phycol. 41, 506-514.

Evans, K.M., Wortley, A.H., Mann, D.G., 2007. An assessment of potential diatom "barcode" genes (cox1, rbcL, 18S and ITS rDNA) and their effectiveness in determining relationships in Sellaphora (Bacillariophyta). Protist 158, 349364.

Fawcett, A., Pitcher, G.C., Bernard, S., Cembella, A.D., Kudela, R.M., 2007. Contrasting wind patterns and toxigenic phytoplankton in the southern Benguela upwelling system. Mar. Ecol. Prog. Ser. 348, 19-31.

Fehling, J., Davidson, K., Bolch, C.J., Bates, S.S., 2004a. Growth and domoic acid production by Pseudo-nitzschia seriata (Bacillariophyceae) under phosphate and silicate limitation. J. Phycol. 40, 674-683.

Fehling, J., Green, D.H., Davidson, K., Bolch, C.J., Bates, S.S., 2004b. Domoic acid production by Pseudo-nitzschia seriata (Bacillariophyceae) in Scottish waters. J. Phycol. 40, 622-630.

Fehling, J., Davidson, K., Bates, S.S., 2005. Growth dynamics of non-toxic Pseudonitzschia delicatissima and toxic $P$. seriata (Bacillariophyceae) under simulated spring and summer photoperiods. Harmful Algae 4, 763-769.

Fehling, J., Davidson, K., Bolch, C., Tett, P., 2006. Seasonality of Pseudo-nitzschia spp. (Bacillariophyceae) in western Scottish waters. Mar. Ecol. Prog. Ser. 323, 91105.

Fernandes, L.F., Richlen, M.L., Kulis, D., Erdner, D.L., Bates, S.S., Ehrman, J., McCauley, L.A.R., Libera, K., Liang, J., Anderson, D.M., 2009. The taxonomy and biodiversity of the diatom Pseudo-nitzschia H. Peragallo in the Gulf of Maine: characterizing an emerging threat in the region. In: Fifth Symposium on Harmful Algae in the U.S., Ocean Shores, WA, November 15-19, 2009, p. 40

Fernandes, L.F., Brandini, F.P., 2010. The potentially toxic diatom Pseudo-nitzschia H. Peragallo in the Paraná and Santa Catarina States, Southern Brazil. Iheringia. Ser. Bot. 65, 47-62.

Ferrario, M. Licea, S., Balestrini, C.F. Ferreyra, G. 2004. Species of Pseudo-nitzschia in the Drake Passage $\left(54^{\circ}-61^{\circ} \mathrm{S}\right.$ to $\left.46^{\circ}-64^{\circ} \mathrm{W}\right)$. In: Steidinger, K.A., Landsberg, J.H., Tomas, C.R., Vargo, G.A. (Eds.), Harmful Algae 2002. Florida Fish and Wildlife Conservation Commission. Florida Institute of Oceanography, and Intergovernmental Oceanographic Commission of UNESCO, St. Petersburg, FL, USA, pp. 434-436.

Ferrario, M.E., Sar, E.A., Castanos, C., Hinz, F., 1999. Potentially toxic species of the diatom genus Pseudo-nitzschia in Argentinian coastal waters. Nova Hedwigia $68,131-147$

Ferrario, M.E., Sar, E.A., Sala, S.E., 2002. Diotomeas potencialmente toxigenas de Cono Sur Americano. In: Sar, E.A., Ferrario, M.E., Reguera, B. (Eds.), Floraciones Algales Nocivas en el Cono Sur Americano. Instituto Español de Oceanografía, Madrid, pp. 167-194.

Fire, S.E., Silver, M.W., 2005. Domoic acid in the Santa Cruz wharf fishery. Calif. Fish Game 91, 179-192.

Fire, S.E., Wang, Z.H., Leighfield, T.A., Morton, S.L., Mcfee, W.E., McLellan, W.A., Litaker, R.W., Tester, P.A., Hohn, A.A., Lovewell, G., Harms, C., Rotstein, D.S. Barco, S.G., Costidis, A., Sheppard, B., Bossart, G.D., Stolen, M., Durden, W.N., Van Dolah, F.M., 2009. Domoic acid exposure in pygmy and dwarf sperm whales (Kogia spp.) from southeastern and mid-Atlantic US waters. Harmful Algae 8, 658-664.

Fire, S.E., Wang Z.H. Berman, M., Langlois, G.W., Morton, S.L, Sekula-Wood, E., Benitez-Nelson, C.R., 2010. Trophic transfer of the harmful algal toxin domoic acid as a cause of death in a minke whale (Balaenoptera acutorostrata) stranding in southern California. Aquat. Mamm. 36, 342-350.

Fire, S.E., Wang, Z.H., Byrd, M., Whitehead, H.R., Paternoster, J., Morton, S.L., 2011. Co-occurrence of multiple classes of harmful algal toxins in bottlenose dolphins (Tursiops truncatus) stranding during an unusual mortality event in Texas, USA Harmful Algae 10, 330-336.

Forbes, J.R., Denman, K.L., 1991. Distribution of Nitzschia pungens in coastal waters of British Columbia. Can. J. Fish. Aquat. Sci. 48, 960-967.

Forbes, J.R., Chiang, R., 1994. Geographic and temporal variability of domoic acid in samples collected for seafood inspection in British Columbia, 1992-1994. In: Forbes, J.R. (Ed.), Fourth Canadian Workshop on Harmful Marine Algae, Sidney, British Columbia, Can. Tech. Rep. Fish. Aquat. Sci. 2016, pp. 11-12.

Fraga, S., Alvarez, M.J., Míguez, Á., Fernández, M.L., Costas, E., López-Rodas, V., 1998. Pseudo-nitzschia species isolated from Galician waters: toxicity, DNA content and lectin binding assay. In: Reguera, B., Blanco, J., Fernández, M.L., Wyatt, T. (Eds.), Harmful Algae. Xunta de Galicia and the IOC of UNESCO, Paris, pp. 270 273.

Fritz, L., Quilliam, M.A., Wright, J.L.C., Beale, A.M., Work, T.M., 1992. An outbreak of domoic acid poisoning attributed to the pennate diatom Pseudo-nitzschia australis. J. Phycol. 28, 439-442.
Fryxell, G.A., Garza, S.A., Roelke, D., 1991. Auxospore formation in an Antarctic clone of Nitzschia subcurvata Hasle. Diatom Res. 6, 235-245.

Fryxell, G.A., Villac, M.C., Shapiro, L.P., 1997. The occurrence of the toxic diatom genus Pseudo-nitzschia (Bacillariophyceae) on the West Coast of the USA, 19201996: a review. Phycologia 36, 419-437.

Gallacher, S., Howard, G., Hess, P., MacDonald, E., Kelly, M.C., Bates, L.A., Brown, N., MacKenzie, M., Gillibrand, P., Turrell, W.R., 2001. The occurrence of amnesic shellfish poisons in shellfish from Scottish waters. In: Hallegraeff, G.M., Blackburn, S.I., Bolch, C.J., Lewis, D. (Eds.), Harmful Algal Blooms 2000: Proceedings of the Ninth International Conference on Harmful Algal Blooms., UNESCO, Hobart, Australia, pp. 30-33.

Gárate-Lizárraga, I., Band-Schmidt, C.J., López-Cortés, D.J., Bustillos-Guzmán, J.J., Erler, K., 2007. Bloom of Pseudo-nitzschia fraudulenta in Bahía de La Paz, Gulf of California (June-July 2006). Harmful Algae News 33, 6-7.

García-Mendoza, E., Rivas, D., Olivos-Ortiz, A., Almázan-Becerril, A., CastañedaVega, C., Peña-Manjarrez, J.L., 2009. A toxic Pseudo-nitzschia bloom in Todos Santos Bay, northwestern Baja California, Mexico. Harmful Algae 8, 493-503.

Garrison, D.L., Conrad, S.M., Eilers, P.P., Waldron, E.M., 1992. Confirmation of domoic acid production by Pseudo-nitzschia australis (Bacillariophyceae) cultures. J. Phycol. 28, 604-607.

Geitler, L., 1935. Reproduction and life history in diatoms. Botanical Rev. 1, 149161.

Gilgan, M.W., Burns, B.G., Landry, G.J., 1990. Distribution and magnitude of domoic acid contamination of shellfish in Atlantic Canada during 1988. In: Granéli, E., Sundström, B., Edler, L., Anderson, D.M. (Eds.), Toxic Marine Phytoplankton. Elsevier, New York, pp. 469-474.

Goldberg, J.D., 2003. Domoic acid in the benthic food web. Masters Thesis. California State University, Monterey Bay, CA. 33 pp.

Gran, H.H., Thompson, T.G., 1930. The Diatoms and the Physical and Chemical Conditions of the Sea Water of the San Juan Archipelago, vol. 7, Puget Sound Biological Station of the University of Washington, pp. 169-204.

Granéli, E., Johansson, N., 2003. Effects of the toxic haptophyte Prymnesium parvum on the survival and feeding of a ciliate: the influence of different nutrient conditions. Mar. Ecol. Prog. Ser. 254, 49-56.

Greenfield, D.I., Marin III, R., Jensen, S., Massion, E., Roman, B., Feldman, J., Scholin, C.A., 2006. Application of environmental sample processor (ESP) methodology for quantifying Pseudo-nitzschia australis using ribosomal RNA-targeted probes in sandwich and fluorescent in situ hybridization formats. Limnol. Oceanogr. Meth. 4, 426-435.

Greenfield, D.I., Marin III, R., Doucette, G.J., Mikulski, C.M., Jones, K., Jensen, S. Roman, B., Alvarado, N., Feldman, J., Scholin, C., 2008. Field applications of the second-generation Environmental Sample Processor (ESP) for remote detection of harmful algae: 2006-2007. Limnol. Oceanogr. Meth. 6, 667-679.

Guannel, M.L., Horner-Devine, M.C., Rocap, G., 2011. Bacterial community composition differs with species and toxigenicity of the diatom Pseudo-nitzschia. Aquat. Microb. Ecol. 64, 117-133.

Gulland, F.M.D., Haulena, M., Fauquier, D., Langlois, G., Lander, M.E., Zabka, T., Duerr, R., 2002. Domoic acid toxicity in Californian sea lions (Zalophus californianus): clinical signs, treatment and survival. Vet. Rec. 150, 475-480.

HAB Report, 2009. Northwest Fisheries Science Center and Washington State Sea Grant, Issue 1. Spring.

Haché, S., 2000. Détermination d'un signal (phéromone) produit par la diatomée toxique Pseudo-nitzschia multiseries ayant un rôle dans la communication sexuelle. Honours Thesis. Université de Moncton, Moncton, NB. 29 pp.

Hagström, J.A., Granéli, E., Moreira, M.O.P., Odebrecht, C., 2011. Domoic acid production and elemental composition of two Pseudo-nitzschia multiseries strains, from the NW and SW Atlantic Ocean, growing in phosphorus- or nitrogen-limited chemostat cultures. J. Plankton Res. 33, 297-308.

Hall, A.J., Frame, E., 2010. Evidence of domoic acid exposure in harbour seals from Scotland: a potential factor in the decline in abundance? Harmful Algae 9, 489493.

Hallegraeff, G.M., 1994. Species of the diatom genus Pseudo-nitzschia in Australian Waters. Bot. Mar. 37, 397-411.

Hanic, L.A., Sekimoto, S., Bates, S.S., 2009. Oomycete and chytrid infections of the marine diatom Pseudo-nitzschia pungens (Bacillariophyceae) from Prince Edward Island, Canada. Botany 87, 1096-1105.

Hansen, L.R., Soylu, S.í, Kotaki, Y., Moestrup, Ø., Lundholm, N., 2011. Toxin production and temperature-induced morphological variation of the diatom Pseudonitzschia seriata from the Arctic. Harmful Algae 10, 689-696.

Hasle, G.R., 1964. Nitzschia and Fragilariopsis species studied in the light and electron microscopes I. Some marine species of the groups Nitzschia and Lanceolateae. Skr. Norske Vidensk-Akad. I. Mat.-Nat. Kl. Ny Serie 16, 1-48.

Hasle, G.R., 1965. Nitzschia and Fragilariopsis species studied in the light and electron microscopes II. The group Pseudonitzschia. Skr. Norske Vidensk-Akad. I. Mat.-Nat. Kl. Ny Series 18, 1-45.

Hasle, G.R., Lange, C.B., Syvertsen, E.E., 1996. A review of Pseudo-nitzschia, with special reference to the Skagerrak, North Atlantic, and adjacent waters. Helgoländer Meeresunters 50, 131-175.

Hasle, G.R., 2002. Are most of the domoic acid-producing species of the diatom genus Pseudo-nitzschia cosmopolites? Harmful Algae 1, 137-146.

Hasle, G.R., Lundholm, N., 2005. Pseudo-nitzschia seriata f. obtusa (Bacillariophyceae) raised in rank based on morphological, phylogenetic and distributional data. Phycologia 44, 608-619.

Hay, B.E., Grant, C.M., McCoubrey, D.-J., 2000. A review of the marine biotoxin monitoring programme for non-commercially harvested shellfish. Part 1: Technical report. A report prepared for the NZ Ministry of Health by AquaBio 
Consultants Ltd. NZ Ministry of Health. Available at http://www.moh.govt.nz/ moh.nsf/0/5486048e2cc88b67cc256a50000ca20a/\$FILE/MarineBiotoxinReport Dec2000.pdf.

Haya, K., Martin, J.L., Burridge, L.E., Waiwood, B.A., Wildish, D.J., 1991. Domoic acid in shellfish and plankton from the Bay of Fundy, New Brunswick, Canada. J. Shellfish Res. 10, 113-118.

Hernández-Becerril, D.U., 1998. Species of the planktonic diatom genus Pseudonitzschia of the Pacific coasts of Mexico. Hydrobiologia 379, 77-84.

Hernández-Becerril, D.U., Díaz-Almeyda, E.M., 2006. The Nitzschia bicapitata group, new records of the genus Nitzschia, and further studies on species of Pseudonitzschia (Bacillariophyta) from Mexican Pacific coasts. Nova Hedwigia 293306.

Hernández-Becerril, D.U., Bravo-Sierra, E., Aké-Castillo, J.A., 2007. Phytoplankton on the western coasts of Baja California in two different seasons in 1998. Sci. Mar. 71, 735-743.

Hillebrand, H., Sommer, U., 1996. Nitrogenous nutrition of the potentially toxic diatom Pseudo-nitzchia pungens f. multiseries Hasle. J. Plankton Res. 18, 295-301.

Hiltz, M., Bates, S.S., Kaczmarska, I., 2000. Effect of light: dark cycles and cell apical length on the sexual reproduction of the pennate diatom Pseudo-nitzschia multiseries (Bacillariophyceae) in culture. Phycologia 39, 59-66.

Holtermann, K.E., Bates, S.S., Trainer, V.L., Odell, A., Armbrust, E.V., 2010. Mass sexual reproduction in the toxigenic diatoms Pseudo-nitzschia australis and $P$. pungens (Bacillariophyceae) on the Washington Coast, USA. J. Phycol. 46, 41-52.

Horner, R., Dick, L.S., Shiels, W.E., 1973. Phytoplankton studies. In: Hood, D.W., Shiels, W.E., Kelly, E.J. (Eds.), Environmental Studies of Port Valdez. Institute of Marine Science, University of Alaska, Fairbanks, pp. 281-294.

Horner, R.A., Kusske, M.B., Moynihan, B.P., Skinner, R.N., Wekell, J.C., 1993. Retention of domoic acid by Pacific razor clams, Siliqua patula (Dixon, 1789): preliminary study. J. Shellfish Res. 12, 451-456.

Horner, R.A., Postel, J.R., 1993. Toxic diatoms in western Washington waters (US west coast). Hydrobiologia 269, 197-205.

Horner, R.A., Hanson, L., Hatfield, C.L., Newton, J.A., 1996. Domoic acid in Hood Canal, Washington, USA. In: Yasumoto, T., Oshima, Y., Fukuyo, Y. (Eds.), Harmful and Toxic Algal Blooms. Intergov. Oceanogr. Comm., UNESCO, Paris. pp. $127-129$.

Horner, R.A., Garrison, D.L., Plumley, F.G., 1997. Harmful algal blooms and red tide problems on the U.S. west coast. Limnol. Oceanogr. 42, 1076-1088.

Howard, M.D.A., Cochlan, W.P., Ladizinsky, N., Kudela, R.M., 2007. Nitrogenous preference of toxigenic Pseudo-nitzschia australis (Bacillariophyceae) from field and laboratory experiments. Harmful Algae 6, 206-217.

Huang, C., Lin, X., Lin, J., Du, H., Dong, Q., 2009. Population dynamics of Pseudonitzschia pungens in Zhelin Bay, China. J. Mar. Biol. Assoc. U. K. 89, 663-668.

Hubbard, K.A., Rocap, G., Armbrust, E.V., 2008. Inter- and intraspecific community structure within the diatom genus Pseudo-nitzschia (Bacillariophyceae). J. Phycol. 44, 637-649.

Illoul, H., Maso, M., Fortuno, J.M., Cros, L., Morales-Blake, A., Seridji, R., 2008. Potentially harmful microalgae in coastal waters of the Algiers area (Southern Mediterranean Sea). Cryptogamie Algol. 29, 261-278.

Jackson, A.E., Ayer, S.W., Laycock, M.V., 1992. The effect of salinity on growth and amino acid composition in the marine diatom Nitzschia pungens. Can. J. Bot. 70, 2198-2201.

James, K.J., Gillman, M., Amandi, M.F., López-Rivera, A., Puente, P.F., Lehane, M., Mitrovic, S., Furey, A., 2005. Amnesic shellfish poisoning toxins in bivalve molluscs in Ireland. Toxicon 46, 852-858.

Jameson, I., Hallegraeff, G.M., 2010. Planktonic diatoms. In: Hallegraeff, G.M., Bolch, C.J.S., Hill, D.R.A., Jameson, I., LeRoi, J.-M., McMinn, A., Murray, S., de Salas, M.F., Saunders, K. (Eds.), Algae of Australia. Phytoplankton of temperate waters. ABRS; CSIRO Publishing, Canberra and Melbourne, pp. 16-82.

Kaczmarska, I., Bates, S.S., Ehrman, J.M., Léger, C., 2000. Fine structure of the gamete, auxospore and initial cell in the pennate diatom Pseudo-nitzschia multiseries (Bacillariophyta). Nova Hedwigia 71, 337-357.

Kaczmarska, I., LeGresley, M.M., Martin, J.L., Ehrman, J., 2005. Diversity of the diatom genus Pseudo-nitzschia Peragallo in the Quoddy Region of the Bay of Fundy, Canada. Harmful Algae 4, 1-19.

Kaczmarska, I., Martin, J.L., Ehrman, J.M., LeGresley, M.M., 2007. Pseudo-nitzschia species population dynamics in the Quoddy Region, Bay of Fundy. Harmful Algae, doi:10.1016/j.hal.2007.05.001.

Kaczmarska, I., Reid, C., Martin, J.L., Moniz, M.B.J., 2008. Morphological, biological and molecular characteristics of Pseudo-nitzschia delicatissima from the Canadian Maritimes. Botany 86, 763-772.

Kawatsu, K., Hamano, Y., 2000. Determination of domoic acid in Japanese mussels by enzyme immunoassay. J. AOAC Int. 83, 1384-1386.

Kjæret, A.H., Naustvoll, L.J., Paasche, E., 2000. Ecology of the heterotrophic dinoflagellate genus Protoperidinium in the inner Oslofjord (Norway). Sarsia 85, 453460.

Klein, C., Claquin, P., Bouchart, V., Le Roy, B., Veron, B., 2010. Dynamics of Pseudonitzschia spp. and domoic acid production in a macrotidal ecosystem of the Eastern English Channel (Normandy, France). Harmful Algae 9, 218-226.

Kreuder, C., Miller, M.A., Jessup, D.A., Lowenstine, L.J., Harris, M.D., Ames, J.A Carpenter, T.E., Conrad, P.A., Mazet, J.A.K., 2003. Patterns of mortality in Southern Sea Otters (Enhydra lutris nereis) from 1998-2001. J. Wildlife Dis. 39, 495-509.

Kudela, R., Cochlan, W., Roberts, A., 2004a. Spatial and temporal patterns of Pseudonitzschia spp. in central California related to regional oceanography. In: Steidinger, K.A., Landsberg, J.H., Tomas, C.R., Vargo, G.A. (Eds.), Harmful Algae 2002. Florida Fish and Wildlife Conservation Commission. Florida Institute of
Oceanography, and Intergovernmental Oceanographic Commission of UNESCO, St. Petersburg, FL, USA, pp. 347-349.

Kudela, R., Roberts, A., Armstrong, M., 2004b. Laboratory analysis of nutrient stress and toxin accumulation in Pseudo-nitzschia species from Monterey Bay, California. In: Steidinger, K., Landsberg, J.H., Tomas, C., Vargo, G. (Eds.), Harmful Algae 2002. Florida Fish and Wildlife Conservation Commission. Florida Institute of Oceanography, and Intergovernmental Oceanographic Commission of UNESCO, St. Petersburg, FL, USA, pp. 136-138.

Kudela, R.M., Lane, J.Q., Cochlan, W.P., 2008. The potential role of anthropogenically derived nitrogen in the growth of harmful algae in California, USA. Harmful Algae 8, 103-110.

Kudela, R.M., Howard, M.D.A., Jenkins, B.D., Miller, P.E., Smith, G.J., 2010. Using the molecular toolbox to compare harmful algal blooms in upwelling systems. Prog. Oceanogr. 85, 108-121.

Kvitek, R.G., Goldberg, J.D., Smith, G.J., Doucette, G.J., Silver, M.W., 2008. Domoic acid contamination within eight representative species from the benthic food web of Monterey Bay, California, USA. Mar. Ecol. Prog. Ser. 367, 35-47.

Lane, J.Q., Roddam, C.M., Langlois, G.W., Kudela, R.M., 2010. Application of Solid Phase Adsorption Toxin Tracking (SPATT) for field detection of the hydrophilic phycotoxins domoic acid and saxitoxin in coastal California. Limnol. Oceanogr. Meth. 8, 645-660.

Langlois, G., 2001-2009. Marine Biotoxin Monitoring Program, Annual Report 2001-2009, California Department of Public Health.

Langlois, G., 2007. Marine Biotoxin Monitoring Program, Annual Report, 2007. California Department of Public Health.

Lapworth, C., Hallegraeff, G.M., Ajani, P.A., 2001. Identification of domoic-acidproducing Pseudo-nitzschia species in Australian waters. In: Hallegraef, G.M., Blackburn, S.I., Bolch, C.J., Lewis, D. (Eds.), Harmful Algal Blooms 2000: Proceedings of the Ninth International Conference on Harmful Algal Blooms, Hobart, Australia, pp. 38-41.

Leandro, L.F., Teegarden, G.J., Roth, P.B., Wang, Z.H., Doucette, G.J., 2010a. The copepod Calanus finmarchicus: a potential vector for trophic transfer of the marine algal biotoxin, domoic acid. J. Exp. Mar. Biol. Ecol. 382, 88-95.

Leandro, L.F., Rolland, R.M., Roth, P.B., Lundholm, N., Wang, Z.H., Doucette, G.J. 2010b. Exposure of the North Atlantic right whale Eubalaena glacialis to the marine algal biotoxin, domoic acid. Mar. Ecol. Prog. Ser. 398, 287-303.

Lee, J.H., Baik, J.H., 1997. Neurotoxin-producing Pseudonitzschia multiseries (Hasle) Hasle, in the coastal waters of Southern Korea. II. Production of domoic acid. Korean J. Phycol. 12, 31-38.

Lefebvre, K.A., Powell, C.L., Busman, M., Doucette, G.J., Moeller, P.D.R., Sliver, J.B. Miller, P.E., Hughes, M.P., Singaram, S., Silver, M.W., Tjeerdema, R.S., 1999 Detection of domoic acid in northern anchovies and California sea lions associated with an unusual mortality event. Nat. Toxins 7, 85-92.

Lefebvre, K.A., Bargu, S., Kieckhefer, T., Silver, M.W., 2002. From sanddabs to blue whales: the pervasiveness of domoic acid. Toxicon 40, 971-977.

Lewitus, A.J., Horner, R.A., Caron, D.A., García-Mendoza, E., Hickey, B.M., Hunter, M., Huppert, D.D., Kelly, D., Kudela, R.M., Langlois, G.W. Largier, J.L., Lessard, E.J., RaLonde, R., Rensel, J., Strutton, P.G., Trainer, V.L., Tweddle, J.F. Harmful Algal blooms along the North American West Coast Region: history, trends, causes, and impacts. Harmful Algae, in press.

Liefer, J.D., MacIntyr, H.L., Novoveska, L., Smith, W.L., Dorsey, C.P., 2009. Temporal and spatial variability in Pseudo-nitzschia spp. in Alabama coastal waters: a "hot spot" linked to submarine groundwater discharge? Harmful Algae 8, 706714.

Lincoln, J.A., Turner, J.T., Bates, S.S., Léger, C., Gauthier, D.A., 2001. Feeding, egg production, and egg hatching success of the copepods Acartia tonsa and Temora longicornis on diets of the toxic diatom Pseudo-nitzschia multiseries and the nontoxic diatom Pseudo-nitzschia pungens. Hydrobiologia 453, 107-120.

López-Rivera, A., Pinto, M., Insinilla, A., Isla, B.S., Uribe, E., Alvarez, G., Lehane, M., Furey, A., James, K.J., 2009. The occurrence of domoic acid linked to a toxic diatom bloom in a new potential vector: the tunicate Pyura chilensis (piure). Toxicon 54, 754-762.

Loureiro, S., Newton, A., Icely, J.D., 2005. Microplankton composition, production and upwelling dynamics in Sagres (SW Portugal) during the summer of 2001 Sci. Mar. 69, 323-341.

Loureiro, S., Garcés, E., Fernández-Tejedor, M., Vaqué, D., Camp, J., 2009a. Pseudonitzschia spp. (Bacillariophyceae) and dissolved organic matter (DOM) dynamics in the Ebro Delta (Alfacs Bay, NW Mediterranean Sea). Estuar. Coast. Shelf Sci. 83, 539-549.

Loureiro, S., Jauzein, C., Garcés, E., Collos, Y., Camp, J., Vaqué, D., 2009b. The significance of organic nutrients in the nutrition of Pseudo-nitzschia delicatissima (Bacillariophyceae). J. Plankton Res. 31, 399-410.

Lund-Hansen, L.C., Vang, T., 2004. An inflow and intrusion event in the Little Belt at the North Sea-Baltic Sea transition and a related sub-surface bloom of Pseudonitzschia pseudodelicatissima. Estuar. Coast. Shelf Sci. 59, 265-276.

Lundholm, N., Skov, J., Pocklington, R., Moestrup, Ø., 1994. Domoic acid, the toxic amino acid responsible for amnesic shellfish poisoning, now in Pseudo-nitzschia seriata (Bacillariophyceae) in Europe. Phycologia 33, 475-478.

Lundholm, N., Skov, J., Pocklington, R., Moestrup, Ø., 1997. Studies on the marine planktonic diatom Pseudo-nitzschia. 2. Autecology of P. pseudodelicatissima based on isolates from Danish coastal waters. Phycologia 36, 381-388.

Lundholm, N., Daugbjerg, N., Moestrup, Ø., 2002a. Phylogeny of the Bacillariaceae with emphasis on the genus Pseudo-nitzschia (Bacillariophyceae) based on partial LSU rDNA. Eur. J. Phycol. 37, 115-134.

Lundholm, N., Hasle, G.R., Fryxell, G.A., Hargraves, P.E., 2002b. Morphology, phylogeny and taxonomy of species within the Pseudo-nitzschia americana complex 
(Bacillariophyceae) with descriptions of two new species, Pseudo-nitzschia brasiliana and Pseudo-nitzschia linea. Phycologia 41, 480-497.

Lundholm, N., Moestrup, Ø., 2002. The marine diatom Pseudo-nitzschia galaxiae sp. nov. (Bacillariophyceae): morphology and phylogenetic relationships. Phycologia 41, 594-605.

Lundholm, N., Moestrup, Ø., Hasle, G.R., Hoef-Emden, K., 2003. A study of the Pseudo-nitzschia pseudodelicatissima/cuspidata complex (Bacillariophyceae): what is P. pseudodelicatissima? J. Phycol. 39, 797-813.

Lundholm, N., Hansen, P.J., Kotaki, Y., 2004. Effect of pH on growth and domoic acid production by potentially toxic diatoms of the genera Pseudo-nitzschia and Nitzschia. Mar. Ecol. Prog. Ser. 273, 1-15.

Lundholm, N., Andersen, P., Jørgensen, K., Ring Thorbjørnsen, B., Cembella, A., Krock, B., 2005a. Domoic acid in Danish blue mussels due to a bloom of Pseudonitzschia seriata. Harmful Algae News 29, 8-10.

Lundholm, N., Hansen, P.J., Kotaki, Y., 2005b. Lack of allelopathic effects of the domoic acid-producing marine diatom Pseudo-nitzschia multiseries. Mar. Ecol. Prog. Ser. 288, 21-33.

Lundholm, N., Moestrup, Ø., Kotaki, Y., Hoef-Emden, K., Scholin, C., Miller, P., 2006 Inter- and intraspecific variation of the Pseudo-nitzschia delicatissima complex (Bacillariophyceae) illustrated by rRNA probes, morphological data and phylogenetic analyses. J. Phycol. 42, 464-481.

Lundholm, N., Clarke, A., Ellegaard, M., 2010. A 100-year record of changing Pseudonitzschia species in a sill-fjord in Denmark related to nitrogen loading and temperature. Harmful Algae 9, 449-457.

Lundholm, N., 2011. Bacillariophyta. IOC-UNESCO Taxonomic Reference List of Harmful Micro Algae. Available online at http://www.marinespecies.org/HAB (accessed on 28.06.11)

Lundholm, N., Bates, S.S., Baugh, K.A., Bill, B.D., Connell, L.B., Léger, C., Trainer, V.L. Cryptic and pseudocryptic diversity in diatoms-with descriptions of Pseudonitzschia hasleana sp. nov. and P. fryxelliana sp. nov. J. Phycol., in press.

MacFadyen, A., Hickey, B.M., Cochlan, W.P., 2008. Influences of the Juan de Fuca Eddy on circulation, nutrients, and phytoplankton production in the northern California Current System. J. Geophys. Res. 113, C08008, doi:10.1029/2007JC004412.

MacFadyen, A., Hickey, B.M., 2010. Generation and evolution of a topographically linked, mesoscale eddy under steady and variable wind-forcing. Cont. Shelf Res 30, 1387-1402.

MacIntyre, H.L., Stutes, A.L., Smith, W.L., Dorsey, C.P., Abraham, A., Dickey, R.W. 2011. Environmental correlates of community composition and toxicity during a bloom of Pseudo-nitzschia spp. in the northern Gulf of Mexico. J. Plankton Res. 33, 273-295.

Mackenzie, A.L., White, D.A., Sim, P.G., Holland, A.J., 1993. Domoic acid and the New Zealand greenshell mussel (Perna canaliculus). In: Smayda, T.J., Shimizu, Y. (Eds.), Toxic Phytoplankton Blooms in the Sea. Elsevier Science Publishers, pp. 607-612.

Mafra Jr., L.L., Fernandes, L.F., Proença, L.A.O., 2006. Harmful algae and toxins in Paranaguá Bay, Brazil: bases for monitoring. Braz. J. Oceanogr. 54, 107121.

Mafra Jr., L.L., Bricelj, V.M., Ouellette, C., Léger, C., Bates, S.S., 2009a. Mechanisms contributing to low domoic acid uptake by oysters feeding on Pseudo-nitzschia cells. I. Filtration and pseudofeces production. Aquat. Biol. 6, 201-212.

Mafra Jr., L.L., Bricelj, V.M., Ward, J.E., 2009b. Mechanisms contributing to low domoic acid uptake by oysters feeding on Pseudo-nitzschia cells. II. Selective rejection. Aquat. Biol. 6, 213-226.

Mafra Jr., L.L., Bricelj, V.M., Fennel, K., 2010a. Domoic acid uptake and elimination kinetics in oysters and mussels in relation to body size and anatomical distribution of toxin. Aquat. Toxicol. 100, 17-29.

Mafra Jr., L.L., Bricelj, V.M., Ouellette, C., Bates, S.S., 2010b. Feeding mechanics as the basis for differential uptake of the neurotoxin domoic acid by oysters, Crassostrea virginica, and mussels, Mytilus edulis. Aquat. Toxicol. 97, 160171.

Maldonado, M.T., Hughes, M.P., Rue, E.L., Wells, M.L., 2002. The effect of Fe and Cu on growth and domoic acid production by Pseudo-nitzschia multiseries and Pseudonitzschia australis. Limnol. Oceanogr. 47, 515-526.

Maneiro, I., Iglesias, P., Guisande, C., Riveiro, I., Barreiro, A., Zervoudaki, S., Granéli, E., 2005. Fate of domoic acid ingested by the copepod Acartia clausi. Mar. Biol. 148 $123-130$.

Mann, D.G., Evans, K.M., 2007. Molecular genetics and the neglected art of diatomics. In: Brodie, J., Lewis, J. (Eds.), Unravelling the Algae-The Past, Present and Future of Algal Systematics. CRC Press, Boca Raton, FL, pp. 231-265

Marangoni, C., Pienaar, R.N., Sym, S.D., Pitcher, G.C., 2001. Pseudo-nitzschia australis Frenguelli from Lambert's Bay, South Africa. In: Proceedings of the Microscopy Society of Southern Africa, Johannesburg, South Africa, p. 53.

Marchetti, A., Trainer, V.L., Harrison, P.J., 2004. Environmental conditions and phytoplankton dynamics associated with Pseudo-nitzschia abundance and domoic acid in the Juan de Fuca eddy. Mar. Ecol. Prog. Ser. 281, 1-12.

Marchetti, A., Maldonado, M.T., Lane, E.S., Harrison, P.J., 2006. Iron requirements of the pennate diatom Pseudo-nitzschia: Comparison of oceanic (high-nitrate, lowchlorophyll waters) and coastal species. Limnol. Oceanogr. 51, 2092-2101.

Marchetti, A., Lundholm, N., Kotaki, Y., Hubbard, K., Harrison, P.J., Armbrust, E.V. 2008. Identification and assessment of domoic acid production in oceanic Pseudo-nitzschia (Bacillariophyceae) from iron-limited waters in the northeast subarctic Pacific. J. Phycol. 44, 650-661.

Martin, J.L., Haya, K., Burridge, L.E., Wildish, D.J., 1990. Nitzschia pseudodelicatissima-a source of domoic acid in the Bay of Fundy, eastern Canada. Mar. Ecol. Prog. Ser. 67, 177-182.
McDonald, S.M., Sarno, D., Zingone, A., 2007. Identifying Pseudo-nitzschia species in natural samples using genus-specific PCR primers and clone libraries. Harmful Algae 6, 849-860.

Medina, D., Ferrari, G., Méndez, S., Inocente, G., Giudice, H., Méndez, E., Salhi, M., Odizzio, M., Otero, M.D., 2003. Shellfish monitoring program in Uruguay. In: Villalba, A., Reguera, B., Romalde, J.L., Beiras, R. (Eds.), Molluscan Shellfish Safety. Xunta de Galicia and Intergovernmental Oceanographic Commission of UNESCO, pp. 197-202.

Medlin, L.K., Kooistra, W.H.C.F., 2010. Methods to estimate the diversity in the marine photosynthetic protist community with illustrations from case studies: a review. Diversity 2, 973-1014.

Méndez, S., Ferrario, M., 2009. First report of Pseudo-nitzschia multistrata in Uruguay-January 2009. Harmful Algae News 40, 5-6.

Mengelt, C., 2005. A mechanism coupling sewage effluent to the dark survival of the toxic diatom Pseudo-nitzschia sp. and subsequent initiation of toxic blooms by coastal upwelling. UC Marine Council Coastal Water Quality Initiative, eScholarship repository, Univ. California, No. 012.

Mercado, J.M., Ramírez, T., Cortés, D., Sebastian, M., Vargas-Yáñez, M., 2005. Seasonal and inter-annual variability of the phytoplankton communities in an upwelling area of the Alboran Sea (SW Mediterranean Sea). Sci. Mar. 69, 451465.

Míguez, Á., Fernández, M.L., Fraga, S., 1996. First detection of domoic acid in Galicia (NW of Spain). In: Yasumoto, T., Oshima, Y., Fukuyo, Y. (Eds.), Harmful and Toxic Algal Blooms, Intergov. Oceanogr. Comm., UNESCO, Paris, pp. 143-145.

Miller, R.L., Kamykowski, D.L., 1986. Effects of temperature, salinity, irradiance and diurnal periodicity on growth and photosynthesis in the diatom Nitzschia americana: light-saturated growth. J. Phycol. 22, 339-348.

Moita, M.T., 2001. Estrutura, variabilidade e dinâmica do fitoplâncton na Costa de Portugal Continental. Ph.D. Thesis. University of Lisbon, Portugal. 272 pp.

Moniz, M.B.J., Kaczmarska, I., 2009. Barcoding diatoms: is there a good marker? Mol. Ecol. Resour. 9, 65-74.

Moschandreou, K.K., Papaefthimiou, D., Katikou, P., Kalopesa, E., Panou, A., Nikolaidis, G., 2010. Morphology, phylogeny and toxin analysis of Pseudo-nitzschia pseudodelicatissima (Bacillariophyceae) isolated from the Thermaikos Gulf, Greece. Phycologia 49, 260-273.

Munilla, I., 1997. Henslow's swimming crab (Polybius henslowii) as an important food for yellow-legged gulls (Larus cachinnans) in NW Spain. ICES J. Mar. Sci. 54 631-634.

Naar, J., Kubanek, J., Bourdelais, A., Richard, D., Tomas, C., Baden, D.G., Wright, J.L.C., 2002. Chemical characterization of marine biotoxins involved in an epizootic event of zoo animals in Newport, Kentucky. In: Xth International Conference on Harmful Algae, UNESCO, St. Pete Beach, Florida, p. 211.

Nagasaki, K., Tomaru, Y., Takao, Y., Nishida, K., Shirai, Y., Suzuki, H., Nagumo, T., 2005. Previously unknown virus infects marine diatom. Appl. Environ. Microbiol. 71, 3528-3535.

Negri, R.M., Inza, D., 1998. Some potentially toxic species of Pseudo-nitzschia in the Argentine Sea. In: Reguera, B., Blanco, J., Fernández, M.L., Wyatt, T. (Eds.), Harmful Algae. Xunta de Galicia and the IOC of UNESCO, Paris, pp. 84-85.

Negri, R.M., Montoya, N.G., Carreto, J.I., Akselman, R., Inza, D., 2004. Pseudo-nitzschia australis, Mytilus edulis, Engraulis anchoita and domoic acid in the Argentine Sea. In: Steidinger, K.A., Landsberg, J.H., Tomas, C.R., Vargo, G.A. (Eds.), Harmful Algae 2002. Florida Fish and Wildlife Conservation Commission. Florida Institute of Oceanography, and Intergovernmental Oceanographic Commission of UNESCO, St. Petersburg, FL, USA, pp. 139-141.

Nézan, E., Antoine, E., Fiant, L., Amzil, Z., Billard, C., 2006. Identification of Pseudonitzschia australis and $P$. multiseries in the Bay of Seine. Was there a relation to presence of domoic acid in king scallops in autumn 2004? Harmful Algae News $31,1-3$

Novaczek, I., Madhyastha, M.S., Ablett, R.F., Donald, A., Johnson, G., Nijjar, M.S., Sims, D.E., 1992. Depuration of domoic acid from live blue mussels (Mytilus edulis). Can. J. Fish. Aquat. Sci. 49, 312-318.

NOWPAP, 2005. Integrated report on harmful algal blooms (HABs) for the NOWPAP region. Northwest Pacific Action Plan, Special Monitoring \& Coastal Environmental Assessment Regional Centre (NOWPAP CEARAC). Northwest Pacific Region Environmental Cooperation Center (NPEC), 65 pp. Available at http:// www.cearac-project.org/cearac-project/integrated-report/habs.pdf.

Ochoa, J.L., Hernández-Becerril, D.U., Lluch-Cota, S., Arredondo-Vega, B.O., NuñezVásquez, E., Heredia-Tapia, A., Pérez-Linares, J., Alonso-Rodríguez, R., 2002. Marine biotoxins and harmful algal blooms in Mexico's Pacific littoral, In: Taylor, F.J.R., Trainer, V.L. (Eds.), Harmful algal blooms in the PICES region of the North Pacific. North Pacific Marine Science Organization (PICES), PICES Scientific Report No. 23, pp. 119-128.

Odebrecht, C., Ferrario, M.E., Ciotti, A.M., Kitzmann, D., Odete, M., Moreira, P., Hinz, F., 2001. The distribution of the diatom Pseudo-nitzschia off southern Brazil and relationships with oceanographic conditions. In: Hallegraeff, G.M., Blackburn, S.I., Bolch, C.J., Lewis, R.J. (Eds.), Harmful Algal Blooms 2000. Intergovernmental Oceanographic Commission of UNESCO, Paris, pp. 42-45.

Olson, M.B., Lessard, E.J., 2010. The influence of the Pseudo-nitzschia toxin, domoic acid, on microzooplankton grazing and growth: a field and laboratory assessment. Harmful Algae 9, 540-547.

Orive, E., Laza-Martinez, A., Seoane, S., Alonso, A., Andrade, R., Miguel, I., 2010 Diversity of Pseudo-nitzschia in the southeastern Bay of Biscay. Diatom Res. 25, 125-145.

Orlova, T.Y., Stonik, I.V., Aizdaicher, N.A., Bates, S.S., Léger, C., Fehling, J., 2008. Toxicity, morphology and distribution of Pseudo-nitzschia calliantha, P. multistriata and 
P. multiseries (Bacillariophyta) from the northwestern Sea of Japan. Bot. Mar. 51, 297-306.

Orsini, L., Sarno, D., Procaccini, G., Poletti, R., Dahlmann, J., Montresor, M., 2002. Toxic Pseudo-nitzschia multistriata (Bacillariophyceae) from the Gulf of Naples: morphology, toxin analysis and phylogenetic relationships with other Pseudonitzschia species. Eur. J. Phycol. 37, 247-257.

Orsini, L., Procaccini, G., Sarno, D., Montresor, M., 2004. Multiple rDNA ITS-types within the diatom Pseudo-nitzschia delicatissima (Bacillariophyceae) and their relative abundances across a spring bloom in the Gulf of Naples. Mar. Ecol. Prog. Ser. 271, 87-98.

Pan, Y.L., Subba Rao, D.V., Mann, K.H., 1996a. Changes in domoic acid production and cellular chemical composition of the toxigenic diatom Pseudo-nitzschia multiseries under phosphate limitation. J. Phycol. 32, 371-381.

Pan, Y.L., Subba Rao, D.V., Mann, K.H., Li, W.K.W., Harrison, W.G., 1996b. Effects of silicate limitation on production of domoic acid, a neurotoxin, by the diatom Pseudo-nitzschia multiseries 2. Continuous culture studies. Mar. Ecol. Prog. Ser. $131,235-243$.

Pan, Y.L., Subba Rao, D.V., Mann, K.H., Brown, R.G., Pocklington, R., 1996c. Effects of silicate limitation on production of domoic acid, a neurotoxin, by the diatom Pseudo-nitzschia multiseries 1. Batch culture studies. Mar. Ecol. Prog. Ser. 131, 225-233.

Pan, Y.L., Parsons, M.L., Busman, M., Moeller, P.D.R., Dortch, Q., Powell, C.L., Doucette, G.J., 2001. Pseudo-nitzschia sp. cf. pseudodelicatissima-a confirmed producer of domoic acid from the northern Gulf of Mexico. Mar. Ecol. Prog. Ser. 220, 83-92.

Panggabean, L.M.G., 2007. Pseudo-nitzschia pseudodelicatissima isolated from Hurun Bay: salinity tolerance and domoic acid content. Biota 12, 40-46.

Parsons, M.L., Dortch, Q., Fryxell, G.A., 1998. A multi-year study of the presence of potential domoic acid-producing Pseudo-nitzschia species in the coastal and estuarine waters of Louisiana, USA. In: Reguera, B., Blanco, J., Fernández, M.L., Wyatt, T. (Eds.), Harmful Algae. Xunta de Galicia and the IOC of UNESCO, Paris, pp. 184-187.

Parsons, M.L., Scholin, C.A., Miller, P.E., Doucette, G.J., Powell, C.L., Fryxell, G.A., Dortch, Q., Soniat, T.M., 1999. Pseudo-nitzschia species (Bacillariophyceae) in Louisiana coastal waters: molecular probe field trials, genetic variability, and domoic acid analyses. J. Phycol. 35, 1368-1378.

Parsons, M.L., Dortch, Q., Turner, R.E., 2002. Sedimentological evidence of an increase in Pseudo-nitzschia (Bacillariophyceae) abundance in response to coastal eutrophication. Limnol. Oceanogr. 47, 551-558.

Penna, A., Bertozzini, E., Battocchi, C., Galluzzi, L., Giacobbe, M.G., Vila, M., Garcés, E., Luglie, A., Magnani, M., 2007. Monitoring of HAB species in the Mediterranean Sea through molecular methods. J. Plankton Res. 29, 19-38.

Pérez, F.F., Padín, X.A., Pazos, Y., Gilcoto, M., Cabanas, M., Pardo, P.C., Doval, M.D. Farina-Busto, L., 2010. Plankton response to weakening of the Iberian coastal upwelling. Global Change Biol. 16, 1258-1267.

Perl, T.M., Bédard, L., Kosatsky, T., Hockin, J.C., Todd, E.C.D., Remis, R.S., 1990. An outbreak of toxic encephalopathy caused by eating mussels contaminated with domoic acid. New Engl. J. Med. 322, 1775-1780.

Pitcher, G.C., Calder, D., 2000. Harmful algal blooms of the southern Benguela Current: a review and appraisal of monitoring from 1989 to 1997. S. Afr. J. Mar. Sci. 22, 255-271.

Powell, C.L., Ferdin, M.E., Busman, M., Kvitek, R.G., Doucette, G.J., 2002. Development of a protocol for determination of domoic acid in the sand crab (Emerita analoga): a possible new indicator species. Toxicon 40, 485-492.

Procopiak, L.K., Fernandes, L.F., Moreira Filho, H., 2006. Diatomáceas (Bacillariophyta) marinhas e estuarinas do Paraná, Sul do Brasil: lista de espécies com ênfase em espécies nocivas, Biota Neotropica 6 (3) On-line version ISSN 16760603.

Qi, Y., Wang, J., Zheng, L., 1994. The taxonomy and bloom ecology of Pseudo-nitzschia on the coasts of China. In: IOC-WESTPAC Third International Scientific Symposium, Bali, Indonesia, pp. 88-95.

Quijano-Scheggia, S., Garcés, E., Sampedro, N., van Lenning, K., Flo, E., Andree, K., Fortuno, J.M., Camp, J., 2008. Identification and characterisation of the dominant Pseudo-nitzschia species (Bacillariophyceae) along the NE Spanish coast (Catalonia, NW Mediterranean). Sci. Mar. 72, 343-359.

Quijano-Scheggia, S., Garcés, E., Andree, K., Fortuno, J.M., Camp, J., 2009a. Homothallic auxosporulation in Pseudo-nitzschia brasiliana (Bacillariophyta). J. Phycol. 45, 100-107.

Quijano-Scheggia, S.I., Garcés, E., Lundholm, N., Moestrup, $\varnothing$., Andree, K., Camp, J., 2009b. Morphology, physiology, molecular phylogeny and sexual compatibility of the cryptic Pseudo-nitzschia delicatissima complex (Bacillariophyta), including the description of $P$. arenysensis sp. nov. Phycologia 48, 492-509.

Quijano-Scheggia, S., Olivos-Ortiz, A., Gaviño-Rodríguez, J.H., Castro-Ochoa, F., Rivera-Vilarelle, M., Galicia-Pérez, M., Patiño-Barragan, M., 2011. First report of Pseudo-nitzschia brasiliana and P. micropora (Bacillariophyceae) found in Cuyutlan Lagoon, Mexico. Rev. Biol. Mar. Oceanogr. 46, 189-197.

Radan, R.L., 2008. Nitrogen uptake and domoic acid production by the toxigenic diatom Pseudo-nitzschia multiseries. Masters Thesis. San Francisco State University, San Francisco, CA. 126 pp.

Rhodes, L., White, D., Syhre, M., Atkinson, M., 1996. Pseudo-nitzschia species isolated from New Zealand coastal waters: domoic acid production in vitro and links with shellfish toxicity. In: Yasumoto, T., Oshima, Y., Fukuyo, Y. (Eds.), Harmful and Toxic Algal Blooms, Intergov. Oceanogr. Comm. UNESCO, Paris, pp. 155-158.

Rhodes, L., Scholin, C., Garthwaite, I., 1998. Pseudo-nitzschia in New Zealand and the role of DNA probes and immunoassays in refining marine biotoxin monitoring programmes. Natural Toxins 6, 105-111.
Rhodes, L., Holland, P., Adamson, J., Selwood, A., McNabb, P., 2004. Mass culture of New Zealand isolates of Pseudo-nitzschia australis for production of a new isomer of domoic acid. In: Steidinger, K., Landsberg, J.H., Tomas, C., Vargo, G.A. (Eds.), Harmful Algae 2002. Florida Fish and Wildlife Conservation Commission. Florida Institute of Oceanography, and Intergovernmental Oceanographic Commission of UNESCO, St. Petersburg, FL, USA, pp. 125-127.

Rhodes, L.L., Adamson, J., Scholin, C., 2000. Pseudo-nitzschia multistriata (Bacillariophyceae) in New Zealand. N Zeal. J. Mar. Freshwater Res. 34, 463-467.

Rhodes, L.L., Mackenzie, A.L., Kaspar, H.F., Todd, K.E., 2001. Harmful algae and mariculture in New Zealand. ICES J. Mar. Sci. 58, 398-403.

Ribalet, F., Marchetti, A., Hubbard, K.A., Brown, K., Durkin, C.A., Morales, R., Robert, M., Swalwell, J.E., Tortell, P.D., Armbrust, E.V., 2010. Unveiling a phytoplankton hotspot at a narrow boundary between coastal and offshore waters. Proc. Natl. Acad. Sci. U.S.A. 107, 16571-16576.

Rines, J.E.B., Donaghay, P.L., Dekshenieks, M.M., Sullivan, J.M., Twardowski, M.S., 2002. Thin layers and camouflage: hidden Pseudo-nitzschia spp. (Bacillariophyceae) populations in a fjord in the San Juan Islands, Washington, USA. Mar. Ecol. Prog. Ser. 225, 123-137.

Rue, E., Bruland, K., 2001. Domoic acid binds iron and copper: a possible role for the toxin produced by the marine diatom Pseudo-nitzschia. Mar. Chem. 76, 127134.

Sahraoui, I., Hlaili, A.S., Hadj Mabrouk, H., Léger, C., Bates, S.S., 2009. Blooms of the diatom genus Pseudo-nitzschia H. peragallo in Bizerte Lagoon (Tunisia, SW Mediterranean). Diatom Res. 24, 175-190.

Sahraoui, I., Bates, S.S., Bouchouicha, D., Hadj Mabrouk, H., Sakka Hlaili, A., 2011. Toxic and potentially toxic Pseudo-nitzschia populations in Bizerte Lagoon (Tunisia, SW Mediterranean) during 2006-2007, and first report of domoic acid production by Pseudo-nitzschia brasiliana Lundholm. Hasle, \& G. A. Fryxell. Diatom Res. 26, 293-303.

Santiago-Morales, I.S., García-Mendoza, E., 2011. Growth and domoic acid content of Pseudo-nitzschia australis isolated from northwestern Baja California, Mexico, cultured under batch conditions at different temperatures and two Si:NO3 ratios. Harmful Algae 12, 82-94.

Sar, E.A., Ferraro, M.E., Costaños, C., 1998. Authentication of the type material of Pseudo-nitzschia australis Frenguelli. Diatom Res. 13, 183-185.

Sarno, D., Dahlmann, J., 2000. Production of domoic acid in another species of Pseudo-nitzschia: P. multistriata in the Gulf of Naples (Mediterranean Sea). Harmful Algae News 21, 5.

Sarno, D., Zingone, A., Montresor, M., 2010. A massive and simultaneous sex event of two Pseudo-nitzschia species. Deep-Sea Res. Part II-Topical Studies Oceanogr. 57, 248-255.

Schandelmeier, L., Alexander, V., 1981. An analysis of the influence of ice on spring phytoplankton population structure in the southeast Bering Sea. Limnol. Oceanogr. 26, 935-943.

Schnetzer, A., Miller, P.E., Schaffner, R.A., Stauffer, B.A., Jones, B.H., Weisberg, S.B., DiGiacomo, P.M., Berelson, W.M., Caron, D.A., 2007. Blooms of Pseudo-nitzschia and domoic acid in the San Pedro Channel and Los Angeles harbor areas of the Southern California Bight, 2003-2004. Harmful Algae 6, 372-387.

Scholin, C.A., Marin III, R., Miller, P.E., Doucette, G.J., Powell, C.L., Haydock, P., Howard, J., Ray, J., 1999. DNA probes and a receptor-binding assay for detection of Pseudo-nitzschia (Bacillariophyceae) species and domoic acid activity in cultured and natural samples. J. Phycol. 35, 1356-1367.

Scholin, C.A., Gulland, F., Doucette, G.J., Benson, S., Busman, M., Chavez, F.P., Cordaro, J., DeLong, R., De Vogelaere, A., Harvey, J., Haulena, M., Lefebvre, K., Lipscomb, T., Loscutoff, S., Lowenstine, L.J., Marin III, R., Miller, P.E., McLellan, W.A., Moeller, P.D.R., Powell, C.L., Rowles, T., Silvagni, P., Silver, M., Spraker, T., Trainer, V., Van Dolah, F.M., 2000. Mortality of sea lions along the central California coast linked to a toxic diatom bloom. Nature 403, 80-84.

Schwacke, L.H., Twiner, M.J., De Guise, S., Balmer, B.C., Wells, R.S., Townsend, F.I., Rotstein, D.C., Varela, R.A., Hansen, L.J., Zolman, E.S., Spradlin, T.R., Levin, M., Leibrecht, H., Wang, Z.H., Rowles, T.K., 2010. Eosinophilia and biotoxin exposure in bottlenose dolphins (Tursiops truncatus) from a coastal area impacted by repeated mortality events. Environ. Res. 110, 548-555.

Sekula-Wood, E., Schnetzer, A., Benitez-Nelson, C.R., Anderson, C., Berelson, W.M., Brzezinski, M.A., Burns, J.M., Caron, D.A., Cetinic, I., Ferry, J.L., Fitzpatrick, E. Jones, B.H., Miller, P.E., Morton, S.L., Schaffner, R.A., Siegel, D.A., Thunell, R., 2009. Rapid downward transport of the neurotoxin domoic acid in coastal waters. Nature Geosci. 2, 272-275.

Sekula-Wood, E., Benitez-Nelson, C., Morton, S., Anderson, C., Burrell, C., Thunell, R., 2011. Pseudo-nitzschia and domoic acid fluxes in Santa Barbara Basin (CA) from 1993 to 2008. Harmful Algae 10, 567-575.

Shumway, S.E., 1989. Toxic algae: a serious threat to aquaculture. World Aquacult. $20,65-74$.

Sierra-Beltrán, A.P., Palafox-Uribe, M., Grajales-Montiel, J., Cruz-Villacorta, A., Ochoa, J.L., 1997. Sea bird mortality at Cabo San Lucas, Mexico: evidence that toxic diatom blooms are spreading. Toxicon 35, 447-453.

Sierra-Beltrán, A.P., Cruz, A., Núñez, E., Del Villar, L.M., Cerecero, J., Ochoa, J.L., 1998. An overview of the marine food poisoning in Mexico. Toxicon 36, 1493-1502.

Sierra-Beltrán, A.P., Cortés-Altamirano, R., Cortés-Lara, M.C., 2005. Occurrences of Prorocentrum minimum (Pavillard) in México. Harmful Algae 4, 507-517.

Silver, M.W., Bargu, S., Coale, S.L., Benitez-Nelson, C.R., Garcia, A.C., Roberts, K.J., Sekula-Wood, E., Bruland, K.W., Coale, K.H., 2010. Toxic diatoms and domoic acid in natural and iron enriched waters of the oceanic Pacific. Proc. Natl. Acad. Sci. U.S.A. 107, 20762-20767.

Skov, J., Ton, T.P., Do, T.B.L., 2004. Bacillariophyceae. In: Larsen, J., Nguyen, N.L. (Eds.), Potentially Toxic Microalgae of Vietnam, vol. 140. Opera Bot, pp. 23-51. 
Smith, E.A., Papapanagiotou, E.P., Brown, N.A., Stobo, L.A., Gallacher, S., Shanks, A.M., 2006. Effect of storage on amnesic shellfish poisoning (ASP) toxins in king scallops (Pecten maximus). Harmful Algae 5, 9-19.

Smith, J.C., Cormier, R., Worms, J., Bird, C.J., Quilliam, M.A., Pocklington, R., Angus, R., Hanic, L., 1990. In: Granéli, E., Sundström, B., Edler, L., Anderson, D.M. (Eds.), Toxic blooms of the domoic acid containing diatom Nitzschia pungens in the Cardigan River, Prince Edward Island, in 1988. Toxic Marine Phytoplankton, Elsevier, New York, pp. 227-232.

Smith, J.C., Pauley, K., Cornier, P., Angus, R., Odense, P., O’Neil, D., Quilliam, M.A. Worms, J. 1991. Population dynamics and toxicity of various species of Dinophysis and Nitzschia from the southern Gulf of St. Lawrence. In: Second Canadian Workshop on Harmful Marine Algae, (Gordon, D.C. Jr., Ed.). Can. Tech. Rep. Fish Aquat. Sci. 1799: 25 (abstract)

Sommer, U., 1994. Are marine diatoms favored by high Si:N ratios? Mar. Ecol. Prog. Ser. $115,309-315$.

Spatharis, S., Danielidis, D.B., Tsirtsis, G., 2007. Recurrent Pseudo-nitzschia calliantha (Bacillariophyceae) and Alexandrium insuetum (Dinophyceae) winter blooms induced by agricultural runoff. Harmful Algae 6, 811-822.

Stehr, C.M., Connell, L., Baugh, K.A., Bill, B.D., Adams, N.G., Trainer, V.L., 2002. Morphological, toxicological, and genetic differences among Pseudo-nitzschia (Bacillariophyceae) species in inland embayments and outer coastal waters of Washington State, USA. J. Phycol. 38, 55-65.

Stonik, I.V., Orlova, T., Chikalovets, I.V., Chernikov, O.V., Litvinova, N.G., 2011a Diatoms from the northwestern Sea of Japan as producers of domoic acid. 9 th IST Asia Pacific Meeting on Animal, Plant and Microbial Toxins (International Society on Toxinology, IST), 4-8 September 2011, Vladivostok, Russia, p. 41 (Abstract).

Stonik, I.V., Orlova, T.Tu., Lundholm, N., 2011b. Diversity of Pseudo-nitzschia from the Western North Pacific. Diatom Res. 26, 121-134.

Suárez-Isla, B.A., López, A., Hernández, C., Clément, A., Guzmán, L., 2002. Impacto ecónomico de las floraciones de microalgas nocivas en Chile y datos recientes sobre la ocurrencia de veneno amnésico de los mariscos. In: Sar, E.A., Ferrario, M.E., Reguera, B. (Eds.), Floraciones Algales Nocivas en el Cono Sur Americano. Instituto Español de Oceanografía, Madrid, pp. 257-268.

Sun, J., Hutchins, D.A., Feng, Y.Y., Seubert, E.L., Caron, D.A., Fu, F.X., 2011. Effects of changing $p \mathrm{CO}_{2}$ and phosphate availability on domoic acid production and physiology of the marine harmful bloom diatom Pseudo-nitzschia multiseries. Limnol. Oceanogr. 56, 829-840.

Tahri-Joutei, L., Maghraoui, L.M., Boutaib, R., 2003. Toxic phytoplankton and phycotoxins in the Mediterranean coast of Morocco from 1994 to 2000. In: Villalba, A., Reguera, B., Romalde, J.L., Beiras, R. (Eds.), Molluscan Shellfish Safety. Xunta de Galicia and Intergovernmental Oceanographic Commission of UNESCO, pp. 187-195.

Takahashi, E., Yu, Q., Eaglesham, G., Connell, D.W., McBroom, J., Costanzo, S., Shaw, G.R., 2007. Occurrence and seasonal variations of algal toxins in water, phytoplankton and shellfish from North Stradbroke Island, Queensland, Australia. Mar. Environ. Res. 64, 429-442.

Taylor, F.J.R., Haigh, R., Sutherland, T.F., 1994. Phytoplankton ecology of Sechelt Inlet, a fjord system on the British Columbia coast. II. Potentially harmful species. Mar. Ecol. Prog. Ser. 103, 151-164.

Taylor, F.J.R., Haigh, R., 1996. Spatial and temporal distributions of microplankton during the summers of 1992-1993 in Barkley Sound, British Columbia, with emphasis on harmful species. Can. J. Fish. Aquat. Sci. 53, 2310 2322.

Teitelbaum, J., Carpenter, S., Cashman, N.R., 1990. Neurologic sequelae after ingestion of mussels contaminated with domoic acid. New Engl. J. Med. 323, 16321633.

Tesson, S.V.M., Borra, M., Kooistra, W., Procaccini, G., 2011. Microsatellite primers in the planktonic diatom Pseudo-nitzschia multistrata (Bacillariophyceae). Am. J. Bot. 98, E33-E35

Thessen, A.E., Dortch, Q., Parsons, M.L., Morrison, W., 2005. Effect of salinity on Pseudo-nitzschia species (Bacillariophyceae) growth and distribution. J. Phycol. 41, 21-29.

Thessen, A.E., 2007. Taxonomy and ecophysiology of Pseudo-nitzschia in the Chesapeake Bay. Ph.D. Thesis. University of Maryland, College Park, MD. 231 pp.

Thessen, A.E., Stoecker, D.K., 2008. Distribution, abundance and domoic acid analysis of the toxic diatom genus Pseudo-nitzschia from the Chesapeake Bay. Estuar. Coasts 31, 664-672.

Thessen, A.E., Bowers, H.A., Stoecker, D.K., 2009. Intra- and interspecies differences in growth and toxicity of Pseudo-nitzschia while using different nitrogen sources. Harmful Algae 8, 792-810.

Thompson, S., 2000. The role of bacteria in mediating the sexual reproduction of the domoic-acid-producing diatom Pseudo-nitzschia multiseries (Hasle) Hasle. Special Topics Thesis. Mount Allison University, Sackville, NB. 49 pp.

Trainer, V., Adams, N.G., Bill, B.D., Anulacion, B.F., Wekell, J.C., 1998. Concentration and dispersal of a Pseudo-nitzschia bloom in Penn Cove, Washington, USA. Nat Toxins 6, 113-126

Trainer, V.L., Adams, N.G., Bill, B.D., Stehr, C.M., Wekell, J.C., Moeller, P., Busman, M. Woodruff, D., 2000. Domoic acid production near California coastal upwelling zones, June 1998. Limnol. Oceanogr. 45, 1818-1833.

Trainer, V.L., Hickey, B.M., Horer, R.A., 2002. Biological and physical dynamics of domoic acid production off the Washington coast. Limnol. Oceanogr. 47, 1438 1446.

Trainer, V.L., Eberhart, B.T.L., Wekell, J.C., Adams, N.G., Hanson, L., Cox, F., Dowell, J., 2003. Paralytic shellfish toxins in Puget Sound, Washington State. J. Shellfish Res. 22, 213-223.
Trainer, V.L., Suddleson, M., 2005. Approaches for early warning of domoic acid events in Washington State Oceanography 18, 228-237.

Trainer, V.L., Cochlan, W.P., Erickson, A., Bill, B.D., Cox, F.H., Borchert, J.A., Lefebvre, K.A., 2007. Recent domoic acid closures of shellfish harvest areas in Washington State inland waterways. Harmful Algae 6, 449-459.

Trainer, V.L., Hickey, B.M., Bates, S.S., 2008. Toxic diatoms. In: Walsh, P.J., Smith, S.L., Fleming, L.E., Solo-Gabriele, Gerwick, W.H. (Eds.), Oceans and Human Health: Risks and Remedies from the Seas. Elsevier Science Publishers, New York, pp. 219-237.

Trainer, V.L., Hickey, B.M., Lessard, E.J., Cochlan, W.P., Trick, C.G., Wells, M.L., MacFadyen, A., Moore, S.K., 2009a. Variability of Pseudo-nitzschia and domoic acid in the Juan de Fuca eddy region and its adjacent shelves. Limnol. Oceanogr. 54, 289-308.

Trainer, V.L., Wells, M.L., Cochlan, W.P., Trick, C.G., Bill, B.D., Baugh, K.A., Beall, B.F., Herndon, J., Lundholm, N., 2009b. An ecological study of a massive bloom of toxigenic Pseudo-nitzschia cuspidata off the Washington State coast. Limnol. Oceanogr. 54, 1461-1474.

Trainer, V.L., Pitcher, G.C., Reguera, B., Smayda, T.J., 2010. The distribution and impacts of harmful algal bloom species in eastern boundary upwelling systems. Prog. Oceanogr. 85, 33-52.

Trick, C.G., Bill, B.D., Cochlan, W.P., Wells, M.L., Trainer, V.L., Pickell, L.D., 2010. Iron enrichment stimulates toxic diatom production in high-nitrate, low-chlorophyll areas. Proc. Natl. Acad. Sci. U.S.A. 107, 5887-5892.

Trimborn, S., Lundholm, N., Thoms, S., Richter, K.U., Krock, B., Hansen, P.J., Rost, B., 2008. Inorganic carbon acquisition in potentially toxic and non-toxic diatoms: the effect of $\mathrm{pH}$-induced changes in seawater carbonate chemistry. Physiol. Plant. 133, 92-105.

Tschochner, H., Hurt, E., 2003. Pre-ribosomes on the road from the nucleolus to the cytoplasm. Trends Cell Biol. 13, 255-263.

Turner, R.E., Rabalais, N.N., 1991. Changes in Mississippi River water quality this century. Bioscience 41, 140-147.

Tweddle, J.F., Strutton, P.G., Foley, D.G., O'Higgins, L., Wood, A.M., Scott, B., Everroad, R.C., Peterson, W.T., Cannon, D., Hunter, M., Forster, Z., 2010. Relationships among upwelling, phytoplankton blooms, and phycotoxins in coastal Oregon shellfish. Mar. Ecol. Prog. Ser. 405, 131-145.

Twiner, M.J., Fire, S., Schwacke, L., Davidson, L., Wang, Z.H., Morton, S., Roth, S. Balmer, B., Rowles, T.K., Wells, R.S., 2011. Concurrent exposure of bottlenose dolphins (Tursiops truncatus) to multiple algal toxins in Sarasota Bay, Florida, USA. PLoS ONE 6 e17394. doi:10.1371/journal.pone.0017394.

Ujević, I., Ninčević-Gladan, Ž., Roje, R., Skejić, S., Arapov, J., Marasović, I., 2010. Domoic acid-a new toxin in the Croatian adriatic shellfish toxin profile. Molecules 15, 6835-6849.

Uttal, L., Buck, K.R., 1996. Dietary study of the midwater polychaete Poeobius meseres in Monterey Bay, California. Mar. Biol. 125, 333-343.

Vale, P., Sampayo, M.A. de M., de, M., Quilliam, M.A., 1998. DSP complex toxin profiles relation with Dinophysis spp. occurrence and domoic acid confirmation by LC-MS in Portuguese bivalves. In: Reguera, B., Blanco, J., Fernández, M.L., Wyatt, T. (Eds.), Harmful Algae. Xunta de Galicia and the IOC of UNESCO, Paris, pp. 503-506.

Vale, P., Sampayo, M.A.M., 2001. Domoic acid in Portuguese shellfish and fish. Toxicon 39, 893-904

Vale, P., Sampayo, M.A.M., 2002. Evaluation of marine biotoxin's accumulation by Acanthocardia tuberculatum from Algarve, Portugal. Toxicon 40, 511517.

Vale, P., Botelho, M.J., Rodrigues, S.M., Gomes, S.S., Sampayo, M.A. de M., 2008. Two decades of marine biotoxin monitoring in bivalves from Portugal (1986-2006): a review of exposure assessment. Harmful Algae 7, 11-25.

Vigilant, V.L., Silver, M.W., 2007. Domoic acid in benthic flatfish on the continental shelf of Monterey Bay, California, USA. Mar. Biol. 151, 2053-2062.

Villac, M.C., 1996. Synecology of the genus Pseudo-nitzschia H. Peragallo from Moneterey Bay, California, USA. Ph.D. Thesis. Texas A\&M University, College Station, Texas. 258 pp.

Villac, M.C., Matos, M.G., Santos, V.S., Rodrigues, A.W., Viana, S.C., 2004. Composition and distribution of Pseudo-nitzschia from Guanabara Bay, Brazil: the role of salinity, based on field and culture observations. In: Steidinger, K.A., Landsberg, J.H., Tomas, C.R., Vargo, G.A. (Eds.), Harmful Algae 2002. Florida Fish and Wildlife Conservation Commission, Florida Institute of Oceanography, and Intergovernmental Oceanographic Commission of UNESCO, St. Petersburg, FL, USA, pp. 56-58.

Villac, M.C., Melo, S., Menezes, M., Rivera, D., 2005. Pseudo-nitzschia brasiliana (Bacillariophyceae), an opportunistic diatom on the coast of the state of Rio de Janeiro, Brazil. Atlântica, Rio Grande 27, 139-145.

Vrieling, E.G., Koeman, R.P.T., Scholin, C.A., Scheerman, P., Peperzak, L., Veenhuis, M., Gieskes, W.W.C., 1996. Identification of a domoic acid-producing Pseudonitzschia species (Bacillariophyceae) in the Dutch Wadden sea with electron microscopy and molecular probes. Eur. J. Phycol. 31, 333-340.

Walz, P.M., Garrison, D.L., Graham, W.M., Cattey, M.A., Tjeerdema, R.S., Silver, M.W., 1994. Domoic acid-producing diatom blooms in Monterey Bay, California: 1991-1993. Nat. Toxins 2, 271-279.

Wekell, J.C., Gauglitz, E.J., Barnett, H.J., Hatfield, C.L., Eklund, M., 1994. The occurrence of domoic acid in razor clams (Siliqua patula), dungeness crab (Cancer magister), and anchovies (Engraulis mordax). J. Shellfish Res. 13, 587593.

Wekell, J.C., Trainer, V.L., Ayres, D., Simons, D., 2002. A study of spatial variability of domoic acid in razor clams: recommendations for resource management on the Washington coast. Harmful Algae 1, 35-43. 
Wells, M.L., Trick, C.G., Cochlan, W.P., Hughes, M.P., Trainer, V.L., 2005. Domoic acid: the synergy of iron, copper, and the toxicity of diatoms. Limnol. Oceanogr. 50, 1908-1917.

Whyte, J.N.C., Ginther, N.G., Townsend, L.D., 1995. Formation of domoic acid and fatty acids in Pseudo-nitzschia pungens f. multiseries with scale of culture. J. Appl. Phycol. 7, 199-205.

Windust, A.J., 1992. The responses of bacteria, microalgae, and zooplankton to the diatom Nitzschia pungens f. multiseries and its toxic metabolite domoic acid. M.Sc. Thesis. Dalhousie, $107 \mathrm{pp}$.

Wohlgeschaffen, G.D., Mann, K.H., Subba Rao, D.V., Pocklington, R., 1992. Dynamics of the phycotoxin domoic acid-accumulation and excretion in two commercially important bivalves. J. Appl. Phycol. 4, 297-310.

Work, T.M., Barr, B., Beale, A.M., Fritz, L., Quilliam, M.A., Wright, J.L.C., 1993a. Epidemiology of domoic acid poisoning in brown pelicans (Pelecanus occidentalis) and Brandt's cormorants (Phalacrocorax penicillatus) in California. J. Zoo Wildlife Med. 24, 54-62.

Work, T.M., Beale, A.M., Fritz, L., Quilliam, M.A., Silver, M., Buck, K., Wright, J.L.C., 1993b. Domoic acid intoxication of brown pelicans and cormorants in Santa Cruz, California. In: Smayda, T.J., Shimizu, Y. (Eds.), Toxic Phytoplankton Blooms in the Sea. Elsevier, Amsterdam, pp. 643-650.

Zingone, A., Siano, R., D’Alelio, D., Sarno, D., 2006. Potentially toxic and harmful microalgae from coastal waters of the Campania region (Tyrrhenian Sea, Mediterranean Sea). Harmful Algae 5, 321-337.

Zou, J.Z., Zhou, M.J., Zhang, C., 1993. Ecological features of toxic Nitzschia pungens Grunow in Chinese coastal waters. In: Smayda, T.J., Shimizu, Y. (Eds.), Toxic Phytoplankton Blooms in the Sea. Elsevier Science Publishers, pp. 651-656. 